Customer Switching Behaviour in the Chinese Retail Banking Industry

\author{
A thesis \\ submitted in partial fulfilment \\ of the requirements for the Degree of \\ Master of Commerce and Management
}

at

Lincoln University

by

Dongmei Zhang

Lincoln University, Canterbury, New Zealand

2009 
Abstract of a thesis submitted in partial fulfilment of the requirements for the Degree of M. C. M.

\section{Customer Switching Behaviour in the Chinese Retail Banking \\ Industry}

\section{By Dongmei Zhang}

With the intense competition and increasing globalization in the financial markets, bank management must develop customer-oriented strategies in order to compete successfully in the competitive retail banking environment. The longer a bank can retain a customer, the greater revenue and cost savings from that customer. However, customers are also more prone to changing their banking behaviour when they can purchase nearly identical financial products provided by the retail banks. In order to stay competitive, bank managers need to understand the factors that influence and determine consumer's bank switching behaviour.

With China's accession to the World Trade Organization (WTO), their financial services market was liberalized and deregulated. As a result, customers have a greater choice between domestic and foreign banks. Furthermore, the emergence of the internet allows customers to access financial products without limitation, and increases the Chinese retail banks' ability to prevent customers' switching banks. This 
study identifies and analyses the factors that influence bank customers' switching behaviour in the Chinese retail banking industry.

The findings reveal that Price, Reputation, Service Quality, Effective Advertising, Involuntary Switching, Distance, and Switching Costs have an impact on customers' bank switching behaviour. The results also reveal that the Young Age and High Income Groups are more likely to switch banks.

In general, the results of this research allow service marketers and practitioners to develop and implement services marketing strategies to decrease customer defection rates, and in turn, increase bank profits. Furthermore, this research provides useful information for future researchers who study switching-behaviour in the banking industry.

Keywords: Customer switching behaviour, the Chinese banking industry, logit analysis. 


\section{Acknowledgement}

First of all, I would like to express my deep appreciation to my main supervisor Mr.

Michael D. Clemes, a respectable, responsible and resourceful scholar, who had read and re-read my work repeatedly, thanking him for all the patience, valuable guidance, and perspectives throughout the research. Thank you to my associate supervisor, Dr Christopher Gan, for his abundantly assistance, especially in data collection and analysis of the research findings. Without their exceptional support and encouragement, I could not have completed my thesis.

Thanks and love in abundance to my parents, who provided much support, both financial and emotional. Thanks for their endless love and support that guided me through the hard times when I was staying away from home.

I would like also thank all my friends who had assisted and supported me while writing my thesis. I would like to thank Jonathen, George, Susie, Maggie, Bob, Hunter who assisted me on the statistical methodology analysis and data collection process. My appreciation also goes to postgraduate fellows and staff in the Commerce division for their support and assistance. 


\section{Table of Contents}

$\begin{array}{lll}\text { Abstract } & \text { ii }\end{array}$

Acknowledgement iv

Table of Contents $\quad$ v

$\begin{array}{ll}\text { List of Tables } & \mathbf{x}\end{array}$

$\begin{array}{ll}\text { List of Figures } & \text { xxi }\end{array}$

List of Appendices $\quad$ xii

Chapter 1: Introduction 1

1.1 Introduction 1

1.2 The Banking Industry in China 3

1.3 Previous Research 4

1.4 Research Purpose and Objectives $\quad 6$

$\begin{array}{ll}1.5 \text { Research Contributions } & 7\end{array}$

1.6 Thesis Overview 8

Chapter 2: Literature Review 9

2.1 Introduction 9

2.2 Switching Behaviour 9

2.2.1 The Definition of Switching Behaviour 9

2.2.2 The Effects of Switching Behaviour 9

2.3 Switching Factor 11

$\begin{array}{ll}2.3 .1 \text { Price } & 11\end{array}$

2.3.1.1 The Definition of Price 11

2.3.1.2 The Importance of Price 11

$\begin{array}{ll}2.3 .2 \text { Reputation } & 12\end{array}$

2.3.2.1 The Definition of Reputation 12

2.3.2.2 The Importance of Reputation 12

2.3.3 Service Quality 14

2.3.3.1 The Difference between Services and Goods 14

2.3.3.2 The Definition of Service Quality 15

$\begin{array}{ll}\text { 2.3.3.3 Service Quality Dimensions } & 15\end{array}$ 
2.3.3.4. Empirical Studies on Service Quality Dimensions in the Banking Industry

2.3.3.5 The Importance of Service Quality 17

$\begin{array}{ll}\text { 2.3.3.6 Service Products } & 18\end{array}$

2.3.3.6.1 Service Products Characteristics 19

2.3.3.6.2 The Importance of Service Products 19

2.3.4 Effective Advertising Competition 20

$\begin{array}{ll}\text { 2.3.5 Involuntary Switching } & 21\end{array}$

$\begin{array}{ll}\text { 2.3.6 Distance } & 21\end{array}$

2.3.7 Switching Costs $\quad 22$

2.3.7.1 The Importance of Switching Costs 23

2.3.8 The Demographic Characteristics 24

$\begin{array}{ll}2.4 \text { Chapter Summary } & 24\end{array}$

Chapter 3: Conceptual Gaps and Research Hypotheses 25

3.1 Introduction 25

3.2 Conceptual Gaps in the Literature 25

3.3 Hypotheses Development 25

3.4 Hypotheses and Constructs Relating to Research Objective One, Two and Three 26

3.4.1 Price 26

$\begin{array}{ll}3.4 .2 \text { Reputation } & 27\end{array}$

$\begin{array}{ll}\text { 3.4.3 Service Quality } & 27\end{array}$

3.4.4 Effective Advertising Compeition 28

3.4.5 Involuntary Switching $\quad 29$

3.4.6 Distance 29

3.4.7 Switching Costs 30

3.5 Hypotheses and Constructs Relating to Research Objective Four 31

3.5.1 The Demographic Characteristics Factors 31

3.6 The Theoretical Research Model 33

3.7 Chapter Summary

Chapter 4: Research Methodology 35

4.1 Introduction 35

4.2 Sample Method 35 
4.3 Sample Size 35

4.4 Questionnaire Development 36

4.4.1 Construct Operationalisation 36

4.4.2 Questionnaire Format 38

4.4.3 Pre-testing Procedures $\quad 38$

4.5 Data Collection Procedures 39

4.6 Data Analysis Techniques 39

4.6.1 Factor Analysis 39

4.6.1.1 Modes of Factor Analysis $\quad 40$

4.6.1.2 Types of Factor Analysis $\quad 40$

4.6.1.3 Statistic Assumptions for Factor Analysis 41

4.6.1.4 Test for Determination Appropriateness of Factor Analysis 43

4.6.1.5 Factor Extraction in Principal Components Analysis 44

4.6.1.6 Factor Rotation $\quad 45$

4.6.1.7 Interpretation of Factors $\quad 47$

4.6.2 Summated Scale $\quad 48$

4.6.2.1 Content Validity $\quad 49$

4.6.2.2 Dimensionality $\quad 49$

4.6.2.3 Reliability $\quad 49$

4.6.3 Logistic Regression Analysis $\quad 50$

4.6.3.1 Qualitative Choice Anaysis $\quad 50$

4.6.4 Statistical Assumptions for Regression 58

$\begin{array}{ll}\text { 4.6.4.1 Outliers } & 58\end{array}$

4.6.4.2 Linearity $\quad 58$

4.6.4.3 Multicollinearity $\quad 59$

4.6.4.4 Data Level $\quad 59$

4.6.5 Sensitive Analysis $\quad 59$

4.6.6 T-test and Analysis of Variance (ANOVA) 60

$\begin{array}{ll}\text { 4.6.6.1 T-test } & 61\end{array}$

4.6.6.2 Analysis of Variance (ANOVA) 62

$\begin{array}{ll}4.7 \text { Chapter Summary } & 63\end{array}$

Chapter 5: Results and Discussion $\quad 64$

$\begin{array}{ll}5.1 \text { Introduction } & 64\end{array}$ 
5.2 Sample and Response Rate

$\begin{array}{ll}5.3 \text { Descriptive Statistics } & 65\end{array}$

5.4 Assessment of the Data Set 66

5.4.1 Statistical Assumptions for Factor Analysis 66

5.4.1.1 Examination of the Correlation Matrix 66

5.4.1.2 Inspection of the Anti-Image Correlation Matrix 66

5.4.1.3 Bartlett's Test of Sphericity 67

5.4.1.4 The Kaiser-Meyer-Olkin Measure of Sampling Adequacy 67

$\begin{array}{ll}\text { 5.4.2 Factor Analysis Results } & 67\end{array}$

5.4.2.1 The Latent Roots Criterion 68

5.4.2.2 The Scree Test $\quad 68$

5.4.2.3 Rotation Results $\quad 68$

5.4.2.4 Factor Interpretation $\quad 69$

$\begin{array}{ll}\text { 5.4.3 Assessment of Summated Scales } & 69\end{array}$

5.4.3.1 Content Validity 69

$\begin{array}{ll}\text { 5.4.3.2 Dimensionality } & 70\end{array}$

5.4.3.3 Reliability $\quad 70$

5.4.4 Statistical Assumption for Logistic Regression Models 70

$\begin{array}{ll}\text { 5.4.4.1 Outliers } & 70\end{array}$

$\begin{array}{ll}\text { 5.4.4.2 Multicollinearity } & 71\end{array}$

$\begin{array}{ll}\text { 5.4.4.3 Data Level } & 71\end{array}$

5.5 Results Pertaing to Research Objective One (Hypothesis 1 through 7) 71

5.6 Results Pertaing to Research Objectives Two and Three 73

5.7 Results Pertaing to Research Objective Four (Hypothesis 8 through 15) 75

$\begin{array}{ll}5.8 \text { Chapter Summary } & 78\end{array}$

Chapter 6: Conclusions and Implications $\quad 79$

$\begin{array}{ll}6.1 \text { Introduction } & 79\end{array}$

6.2 Conclusions Pertaining to Research Objective One 79

6.3 Conclusions Pertaining to Research Objective Two \& Three 80

6.4 Conclusions Pertaining to Research Objective Four 81

6.5 Theoretical Implications $\quad 82$

6.6 Managerial Implications $\quad 83$

6.7 Limitations and Avenues for Future Research 89 
6.8 Conclusion

References 


\section{List of Tables}

Table 2.1: SERVQUAL Service Quality Dimensions 15

Table 4.1: Modes for Factor Analysis $\quad 40$

Table 4.2: Guidelines for Identifying Significant Factor Loadings 48

Table 5.1: Descriptive Statistic of Demographic Characteristics 106

Table 5.2: The Correlation Matrix for Switching Behaviour 107

$\begin{array}{ll}\text { Table 5.3: Anti-image Correlation } & 109\end{array}$

Table 5.4: KMO and Bartlett's Test 111

Table 5.5: Factor Extraction 111

Table 5.6: Rotated Component Matrix with VARIMAX Rotation 112

Table 5.7: Pattern Matrix with OBLIMIN Rotation 113

Table 5.8: Questionnaire Items with Orthogonal (VARIMAX) Rotation 114

Table 5.9: The Reliability Test for the Measures of Customers' Switching

$\begin{array}{ll}\text { Behaviour } & 115\end{array}$

Table 5.10: Pearson Correlation Matrix 116

Table 5.11: Logistic Regression Results for Influencing Factors and Demographic

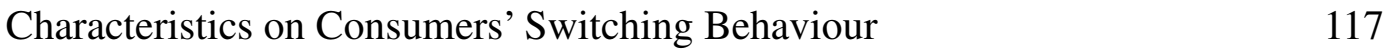

Table 5.12: The Logistic Regression Results for Influencing Factors 72

Table 5.13: Hypotheses 1 to 7 Test Results 72

Table 5.14: Marginal Effects of Customers' Switching Behaviour 74

Table 5.15: Marginal Effects of Customers' demographic characteristics 75

Table 5.16: Hypotheses 8 through 14 Test Results 76

Table 5.17: T-Test: Switching Behaviour Factor Relating to Gender 118

Table 5.18: ANOVA (F-tests) Results Relating to Age 118

Table 5.19: ANOVA (F-tests) Results Relating to Education 119

Table 5.20: ANOVA (F-tests) Results Relating to Income 119

Table 5.21: The Scheffe Output for Age-Multiple Comparisons 120

Table 5.22: The Scheffe Output for Education-Multiple Comparisons 121

Table 5.23: The Scheffe Output for Income -Multiple Comparisons 122 


\section{List of Figure}

Figure 5-1: The Scree Plot 


\section{List of Appendices}

Appendix 1: Cover Letter

Appendix 2: Questionnaire

124 


\section{Chapter 1 Introduction}

\subsection{Introduction}

With the intense competition and increasing globalization of the financial markets, building customer loyalty has become a critical strategy for most financial institutions. The banking industry must develop strong relationships with their customers in order to compete successfully in the competitive retail banking environment. Numerous studies have shown that banks' profitability is closely associated with customer retention (Garland, 2002; Anderson, Fornell \& Lehmann, 1994; Reichheld \& Sasser, 1990). The longer a bank can retain a customer, the greater revenue and cost savings from that customer. Maintaining an existing customer is five times cheaper than obtaining a new one as the advertising, sales, and set-up costs can be amortised over a longer customer lifetime (Morgan, 2007; Clemes, Gan \& Zheng, 2007; Reichheld \& Sasser, 1990).

Duncan \& Elliot (2002) note that customer loyalty is an important factor that contributes to an organization's earnings and profits. Loyal customers normally establish a stable relationship with an organization compared to non-loyal customers (Zeithaml, Berry \& Parasuraman, 1996). Customer loyalty can contribute to an increase in a firm's revenue; reduce customer defection rates; and develop new business through positive word-of-mouth advertising (Reichheld, 1996; O'Brien \& Jones, 1995; Reichheld \& Sasser, 1990). Thus, at the end of the day, the bank's assets are not only primarily registered on the balance sheet, but also related to the fact that customers have been successfully retained (Scharioth, 2002). 
The deregulation and the emergence of new technology in the financial service industry have had a critical impact upon consumer behaviour. When customers can purchase nearly identical financial products provided by the retail banks, customers are also more prone to change their banking behaviour (Beckett, Hewer \& Howcroft, 2000). Chakravarty, Feinberg \& Rhee (2004) state that "the competitiveness of banking combined with the relative homogeneity of banking products and services appears to make banking particularly susceptible to customer switching behaviour" (pp, 512). As a result, service quality or product is no longer the only factor that banks need to focus on as customers are more value-oriented and cautious in making tradeoffs between benefits and costs (Mazumdar, 1993).

To stay competitive, bank providers have to understand their customers in order to not only anticipate, but also to influence banking switching behaviour (Beckett et al., 2000). Furthermore, a detailed understanding of bank customers' switching behaviour can effectively avoid the harmful consequences of defection, and enhance long-term relationships with customers (Lees, Garland \& Wright, 2007; Andreasen, 1988).

Some researchers have studied customer switching behaviour in developed countries (for example, Clemes, Gan \& Zheng, 2007; Colgate \& Hedge, 2001; Gerrard \& Cunningham, 2000; Stewart, 1998; Keaveney, 1995). However, limited studies have focused on developing countries (Zhou, 2004). Due to cultural differences, consumers' evaluation of service quality and associated constructs such as behavioural intention can be considerably different (Smith \& Reynolds, 2001; Furrer, Liu \& Sudharshan, 2000; Winsted, 1997). Cultural differences also pertain to bank switching behaviour (Clemes et al., 2007). This study analyses customer switching behaviour in the Chinese retail banking industry - an economy that was transformed from a centrally planned economy to a market economy (Wang, Lo \& Hui, 2003). 


\subsection{The Banking Industry in China}

Over the past three decades, the centralized banking monopoly in China has been replaced by a relative open and free competitive market (Wang et al., 2003). With China's accession to the World Trade Organization (WTO), the financial services market was liberalized and deregulated allowing foreign banks to offer auto-financing to Chinese customers; operate foreign-currency business without geographic restriction; and conduct local-currency business with foreign clients, Chinese corporations and private individuals (Wang et al., 2003). The Chinese domestic banks inevitably face intensive competition from foreign banks. According to Lannes \& Stratton (2006), there is a potential shift from the Chinese commercial banks to the foreign competitors for those Chinese savers who hold approximately 325 million accounts totalling nearly US\$1.8 trillion.

Since the 1997 nationwide financial reform, the Chinese stated-owned commercial banks have been restructured and commercialized into market-oriented profit entities (Zhou, 2004). The largest commercial banks in China are the Bank of China, the Industrial and Commercial Bank of China, the Agricultural Bank of China, and the China's Construction Bank. In order to compete globally, the Chinese domestic banks have to adopt new technologies, and customise their services. Since the emergence of the internet allows customers to access financial products without limitation, it is increasingly difficult for the Chinese retail banks to prevent customers' switching banks. Furthermore, the slow development of market infrastructure in China limits the capability of domestic banks to develop customer value knowledge (Peng \& Health, 1996). Wang et al. (2003) find that despite many fundamental banking reforms, the Chinese domestic banks are still lagging behind on many fronts compared with their 
foreign competitors - including capitalization, overseas networks, modern management expertise, and experience. Dobson \& Kashyap (2006) summarise that China has been regarded as an attractive market by foreign banks as they believe customers are underserved and many service products are absent. Therefore, it is necessary for the Chinese banks to understand the important drivers that affect customers' switching behaviour.

Wang et al.'s (2003) study shows that offering quality services and products to customers are essentials for success and survival in the Chinese banking environment. Kaynak \& Kucukemiroglu (1992) conduct a bank study in Hong Kong and find that customers do business in Hong Kong in search of convenience, long association, recommendations from friends and relatives, and accessibility to easy credit. Tan \& Chuo (1986) conduct a study of banking customers in Singapore and find that social factors play an important role in influencing customers' intentions regarding bank choice. However, there is a lack of detailed studies on factors that can influence or determine customers' bank switching behaviour in the Chinese retail banking industry (Wang et al., 2003).

\subsection{Previous Research}

Customer switching means customers forsake one service provider for another and switching has become a focus of research in the service sector (Garland, 2002). Several researchers have investigated the reasons why customers switch service providers (Colgate \& Hedge, 2001; Keaveney, 1995; Reichheld \& Sasser, 1990). For example, Colgate \& Hedge (2001) conclude that price, service failures, and denied services are the most important factors that influence customers to switch banks in New Zealand. 
Some researches explain that the broad evaluative constructs of service quality and satisfaction are related to service switching (Mittal \& Laser, 1998; Zeithaml et al. 1996; Bitner, 1990). In general, dissatisfaction is a main factor influencing customers to switch in the insurance industry (Grosby \& Stephen, 1987). However, Jones \& Sasser (1995) and Reichheld (1993) find that there are also high defection rates among satisfied customers in the manufacture industry. Gierl (1993) finds that the percentage of satisfied brand switchers is even greater than the percentage of switchers who are dissatisfied in the retail environment. However, dissatisfied customers may choose to stay because there are no better alternative providers (Bendapudi \& Berry, 1997). Therefore, problems can occur if researchers only focus on broad evaluative concepts of service. It is critical to identify and classify the specific problems, events and nonservice factors that may cause customers' switching behaviour (Gardial, Flint \& Woodruffe, 1996; Levesque \& McDougall, 1996b; Zeithaml et al., 1996).

Keaveney (1995) develops a generalised model to investigate the factors that influence customers to switch service providers. Keaveney (1995) identifies eight incidents relating to service problems and non-service factors that stimulate customers to switch service providers namely: pricing, inconvenience, core service failures, service encounter failures, response to service failure, ethics, competition, and involuntary switching. However, as Keaveny's (1995) research was based on 45 diverse services that included restaurants, hotels, airlines, and travel agents. Thus, generalizing Keaveny's (1995) findings may not be appropriate for the retail banking industry (Andreasen, 1988; Mittal et al., 1998).

The factors that influence a customer's decision to switch in a banking context can be numerous and complex (Steward, 1988). Steward (1998) identifies four switching 
incidents that include: charges and their implementation, facilities and their availability, provision of information and confidentiality, and services issues relating to customers' treatment. In addition, Levesque \& McDougall (1996a) investigate customers' bank switching and complaining behaviour and find that pricing problems and inconvenience of location are important factors that stimulate customers to switch banks.

Based on Keaveny's (1995) study, Gerrard \& Cunningham (2000) develop a simplified weighting method to apply to six postulated switching incidents. These six incidents are: inconvenience, service failures, pricing, unacceptable behavior, attitude or knowledge of staff, involuntary/seldom mentioned incidents, and attraction by competitors. Furthermore, the authors investigate the Asian banking market and find that bank switching is strongly associated with three factors: service failures, pricing, and inconvenience.

Although it is reasonable to assume that customers can be influenced to switch service providers by a single critical incident, many researchers suggest that defection comes from multiple problems encountered over time (Bejou \& Palmer, 1998; Hocutt, 1998). Therefore, studies which focus on only a single factor or failure to investigate all of the actual factors causing customers to switch can only make a limited contribution to the switching behaviour research (Colgate \& Hedge, 2001).

\subsection{Research Purpose and Objectives}

Customers' switching behaviour has been investigated in the service sector, however, there are few empirical studies on developing countries that provide conclusive 
evidence on why customers switch providers. For example, Ehigie (2006) examines how customer expectations, perceived service quality, and satisfaction predict loyalty among bank customers in Nigeria. However, Ehigie's finding is not conclusive for all developing countries and there is a gap in the published literature in the Chinese banking sector. Because of economic, social, political, and cultural differences, it is important to investigate customers' switching behaviour in the Chinese retail banking industry and to test whether the results and findings will be similar to the previous research (Au, Hui \& Leung, 2001).

This study explores the factors influencing customers' bank switching behaviour in the Chinese retail banking industry. The research objectives of this study are:

(1) To identify the factors that influence customers' switching behaviour in the Chinese retail banking industry.

(2) To determine the most important factors that influence customers' switching behaviour in the Chinese retail banking industry.

(3) To determine the least important factors that influence customers' switching behaviour in the Chinese retail banking industry.

(4) To determine the impact of the demographic characteristics on customers' switching behaviour in the Chinese retail banking industry.

\subsection{Research Contribution}

This study will make several contributions to the marketing literature from both a theoretical and a managerial perspective by satisfying the four research objectives. Firstly, this study will contribute to the marketing literature by providing an empirical 
examination of several service marketing constructs. The results of the study will also provide an improved understanding of how price, reputation, service quality, effective advertising competition, involuntary switching, distance, and switching costs influence customers' switching behaviour in the Chinese retail banking industry.

Secondly, this study will benefit marketers and practitioners in the Chinese retail banking industry. This research will identify the most important factors that cause customers to switch or stay with a bank. This knowledge can make a contribution to enhancing long-term customer relationships with bank customers. In addition, bank managers can utilise this knowledge to prevent perspective customers from switching service providers. From the perspective of the banks that are attempting to attract new customers, this information will enable banks to develop strategies to overcome switching barriers and gain market share (Colgate \& Lang, 2001).

\subsection{Thesis Overview}

Chapter One provides an overview of the research problems, statements, and objectives. Chapter Two reviews the literature on switching behaviour and examines the factors influencing switching behaviour in the banking industry. Chapter Three explains the variable selection, theoretical model formulation, and develops 15 testable hypotheses. Chapter Four addresses the data and methodology. Chapter Five presents the research results. Finally, Chapter Six provides the conclusions of the research findings, implications, limitations and directions for future researches. 


\section{Chapter 2 Literature Review}

\subsection{Introduction}

This chapter presents an overview of customers' switching behaviour and examines the effect switching has on the banking industry. The literature review focuses on the major factors influencing customers' bank switching behaviour, such as price, reputation, service quality, effective advertising competition, involuntary switching, distance, and switching costs.

\subsection{Switching Behaviour}

\subsubsection{The Definition of Switching Behaviour}

Switching behaviour is defined as defection or customer exit (Stewart, 1994; Hirschman, 1970). According to Boote (1998) and Bolton \& Bronkhurst (1995), switching behaviour reflects the decision that a customer makes to stop purchasing a particular service or patronising the service firm completely. In a bank industry context, customer switching behaviour means customers' shift from one bank to another (Garland, 2002).

\subsubsection{The Effect of Switching Behaviour}

Keaveney \& Parthasarathy (2001) and Reichheld (1996) find that customers' switching behaviour reduces firms' earnings and profits. Additional profits are lost because the initial investment on the customer (e.g. consulting or advertising costs) are wasted and further costs are required to obtain a new customer (Colgate, Steward \& Kinsella, 1996; Reichheld \& Sasser, 1990; Fornell \& Wernerfelt, 1987). In 
Reichheld \& Sasser's (1990) study, customer defection is seen as having a stronger ability to impact on revenue than on scale, market share, unit costs, and other factors that are usually associated with competitive advantage. Customers tend to behave unfavourably such as switching banks if a bank's performance is inferior (Zeithaml et al., 1996). Furthermore, customer switching can bring negative word-of-mouth advertising which can hurt a bank's reputation and image (Diane, 2003).

The competitive banking industry has been concerned with customers' switching behaviour as it normally reduces a bank's market share and profit (Ennew \& Binks, 1996). Garland (2002), Trubik \& Smith, (2000) and Rust \& Zahorik (1993) study the financial implications of customer retention and find that there is a strong relationship between customer loyalty and profitability in personal retail banking. Since it is hard for banks to meet all customers' requirements, the customer defection rate is quite high in some countries. For example, customer defection rates in the United Stated banks were 20 percents in 1997 \& 1998, and Europe had similar defection rates in the 1990's (Rongstad, 1999; Shedd, 1996). Colgate (1999) investigated the New Zealand bank industry and found hat the annual switching rate was 4 percent, and a further 15 percent of personal retail banking customers intended to switch banks. In order to minimise the negative effects of defection and enhance long-term relationships with customers, researchers have focused their attention on various factors that stimulate customers to switch banks (Matthews \& Murray, 2007; Gerrard \& Cunningham, 2004; Colgate \& Hedge, 2001; Keveaney, 1995). 


\subsection{Switching Factors}

\subsubsection{Price}

\subsubsection{The Definition of Price}

Price is an attribute that must be given up or sacrificed to obtain certain kinds of products or services (Zeithaml, 1998). Perceived price normally combines monetary price and non-monetary price together (Chen, Gupta \& Rom, 1994). In Keaveny's research (1995), the "pricing" factor included all critical switching behaviours that involved prices, rates, fees, charges, surcharges, service charges, penalties, price deals, coupons, and/or price promotions. In the financial service industry, price has wider implications than in other services industries. For example, in the financial service industry, price includes fee implementation, bank charges, interest rates charged and paid (Gerrard \& Cunningham, 2004).

\subsubsection{The Importance of Price}

Customers in general are price conscious in their purchasing behaviour (Beckett et al., 2000; Levesque \& McDougall, 1996a). Price is an important factor in choice situations as a consumer's choices typically relies heavily on the price of alternatives (Engel, Blackwell \& Miniard, 1995). Similarly, Varki \& Colgate (2001) identify that the role of price, as an attribute of performance, can have a direct effect on customer satisfaction and behavioural intentions.

Several studies show that price has an important impact on customers' switching decisions (Stewart, 1998; Colgate et al., 1996; Keaveny, 1995). Almossawi (2001) empirically identifies price as a critical factor in bank selection for college students. Since price has a wider implication to bank customers, Gerrard \& Cunningham (2004) 
show that pricing seems to influence switching behaviour among bank customers more than customers of other services. In Colgate \& Hedge's (2001) study of bank customers' switching behaviour in Australia and New Zealand, the authors identify price as the top switching determinant, followed by service failures and denial of services. Similar results are found in Javalgi, Armaco \& Hoseini's (1989) study investigating the factors influencing customers' bank selection decisions in the United States.

\subsubsection{Reputation}

\subsubsection{The Definition of Reputation}

Reputation has been described as a social identity, and an important and intangible resource that can significantly contribute to a firm's performance and its survival (Rao, 1994; Hall, 1993; Formbrun \& Shanley, 1990). Rust, Zeithaml \& Lemon (2001) and Aaker (1996) define reputation as brand equity or customer equity, and combine it with the credibility and faithfulness of the firm. Reputation is a key asset to firms as it is valuable, distinctive, difficult to duplicate, non-substitutable, and provides the firm with a sustainable competitive advantage (Wang et al., 2003; Hall, 1993). Furthermore, Gerrard \& Cunningham (2004) identify bank reputation as one of the factors that cause customers to switch banks in the Asian market and refer to reputation as the integrity of a bank and the bank's perceived financial stability.

\subsubsection{The Importance of Reputation}

Intensive competition offers customers greater varieties and choices in the market. Thus, reputation is identified by firms in the services sector as an essential part of their competitive strategies. The intangible characteristic of reputation forces researchers to 
analysis reputation with other elements. For example, reputation has been analysed by economists relating to product quality and price (Shapiro, 1983). Product quality and services produce benefits not only by lowering costs, but also by increasing competitiveness through the establishment of a good reputation and the attraction and retention of customers (Wang et al., 2003). In addition, reputation can enhance customer loyalty, especially in the retail banking industry where quality cannot be evaluated accurately before purchase (Nguyen \& Leblanc, 2001; Andreassen \& Lindestad, 1998; Barich \& Kotler, 1991).

Nguyen \& Leblanc (2001) conclude that reputation may be regarded as a critical strategic tool to predict the outcome of the service-production process, and as the most reliable indicator of the ability of a service firm to satisfy a customer's desires. Barr (2009) states that a bank's reputation has a strong effect on customer choice after investigating 7,500 customers in 25 national and regional banks in the United States. Barr's (2009) results show thirty percent of customer deliberately excluded a bank if the bank had perceived financial instability or practiced questionable ethics.

Weigelt \& Camerer (1988) note that a positive reputation is a strategic tool that can be used by banks to earn additional profits. A positive reputation can provide a halo effect for the firm as it positively influences customer evaluations, increases future profits, acts as a barrier to imitation, links to intention to purchases a service, and strengthens the competitive capability of firms (Anderson et al., 1994; Yoon, Guffey \& Kijewski, 1993; Barney, 1991; Formbrun \& Shanley, 1990). 


\subsubsection{Service Quality}

\subsubsection{The Difference between service and goods}

Service is largely intangible and is normally experienced simultaneously with the occurrence of production and consumption, and it is the interaction between the buyer and the seller that renders the service to customers (Gronroos, 1988). In order to distinguish services from goods, Gronroos (1990) identifies five unique characteristics of service: intangibility, inseparability between production, delivery, and consumption, heterogeneity, perishability, and no ordinary transfer of ownership.

\subsubsection{The Definitions of Service Quality}

Since the interactions between a customer and a service provider create opportunities for customers to evaluate services, service quality is defined as a customer's overall impression of the relative inferiority/superiority of the organisation and its service provisions (Gronroos, 1988; Bitner \& Hubbert, 1994). Similarly, Lewis \& Booms (1983) define service quality as a measure of how well the service level delivered matches customer expectations. Perceived service quality is developed from the perspective of a customer's attitude to judge the overall service prevision (Spathis, Petridon \& Glaveli, 2004). Lewis (1989) suggests perceived service quality is a consumer judgement which is derived after comparing consumers' expectations of service with their perceptions of actual service performance. In general, customer expectations can be established from pervious experiences with the organisation, the competitors of an organisation, the traditional marketing mix, or external influences such as word-of-mouth communication (Parasuraman, Zeithaml \& Berry, 1988; Gronroos, 1984b). 
In regards to banking, Kamilia and Jacques (2000) note that perceived service quality results from the gap between customers expectations of the service provided by the bank and the perception of the actual services provided by the bank.

\subsubsection{Service Quality Dimensions}

Lehtinen \& Lehtinen (1982) describe three service quality dimensions: physical quality, which represents the tangible aspects of the service (e.g. machines or building), corporate quality which involves the company's image or profile, and interaction quality which is derived from the interaction between service providers and customers as well as the interaction between customers (Parasuraman, Zeithaml \& Berry 1985).

Gronroos (1984a, 1984b) illustrates three service quality dimensions, namely technical, functional and image qualities. Technical quality is the quality of what the customer is actually receiving from the service; functional quality is the quality of how the service is delivered, and corporate image quality relates to the portrait of a service organisation.

Parasuraman et al. (1988) identify five service quality dimensions for their service quality measurement model-SERVQUAL (see Table 2.1). The five service quality dimensions are: tangibles, reliability, responsiveness, assurance, and empathy. Tangibles relates to the effect of physical facility, equipment, personnel and communication materials on customers, and reliability, responsiveness, assurance, and empathy correspond to the element of human interaction/intervention in delivery of the service. 
Table 2.1: SERVQUAL Service Quality Dimensions (Parasuraman et al., 1998).

\begin{tabular}{|l|l|}
\hline $\begin{array}{l}\text { SERVQUAL } \\
\text { Dimensions }\end{array}$ & Description of SERVQUAL Dimensions \\
\hline Tangibles & Physical facilities, equipment, and appearance of personnel \\
\hline Reliability & Ability to perform the promised service dependably and accurately \\
\hline Responsiveness & Willingness to help customers and promote service \\
\hline Assurance & $\begin{array}{l}\text { Knowledge and courtesy of employees and their ability to inspire } \\
\text { trust and confidence }\end{array}$ \\
\hline Empathy & $\begin{array}{l}\text { Caring such as individualised attention which the employees } \\
\text { provides for its customers }\end{array}$ \\
\hline
\end{tabular}

Several researchers have also demonstrated that service quality is a multi-dimensional construct, and the dimensions can vary across different industries (Clemes, Gan \& Kao, 2007; Alexandiris, Dimitriadis \& Markata, 2002; Brady \& Cronin, 2001; Dabholkar, Thorpe \& Rentz, 1996, Lehtinen \& Lehtinen, 1991).

\subsubsection{Empirical Studies on Service Quality Dimensions in the Banking Industry}

The five SERVQUAL dimensions that identified by Parasurman et al. (1985, 1988, 1991) have been widely used in assessing banking service quality. For example, Levesque \& McDougall (1996) select a series of service quality items based on SERVQUAL measurement in order to find the determinants of customer satisfaction from the bank customer's perspective. Avkiran (1994) examines service quality in the Australia retail banking industry and identifies four dimensions containing 17 items based on the SERVQUAL model. The four dimensions are: staff conduct, credibility, communication, and access to teller services.

Based on Gronroos (1984a) service quality framework, Aldlaigan \& Buttle (2002) propose four dimensions to measure customer service quality perceptions in the retail banking industry. These dimensions are: service system quality, behavioural service 
quality, service transactional accuracy, and machine service quality. Ennew and Bink (1996) study bank customers in the United Kingdom and develop three banking service quality dimensions. These are knowledge, advice offered, personalisation in the service delivery, and general product characteristics.

With the popularity of internet banking services, Jun \& Cai (2001) summarise internet banking service quality from three perspectives: banking service product quality, customer service quality, and online systems quality. Product variety and the diverse features of the service products are categorised into bank service product quality. Customer service quality focuses on the difference between customers' expectations of banks' performance and their evaluation of the services they perceived. Online system quality relates to the quality that the customer perceived when they use the internet. Jun \& Cai (2001) develop seventeen service quality dimensions base on these perspectives.

\subsubsection{The Importance of Service Quality}

Service quality has become a pivotal concern for service industries since consumers are increasingly demanding high quality in their service experiences (Clemes et al., 2007; Leonard \& Sasser, 1982). High service quality can enhance reputation, increase customer retention, attract new customers through word-of-mouth, generate repeat sales, create competitive product difference, and improve financial performance \& profitability of the firms (James 1998; Zeithaml et al., 1996; Julian \& Ramaseshan, 1994).

Many researches find that service quality is associated with customer satisfaction which can lead to behaviour consequence. For example, Bloemer, Ko \& Peeters (1998) identify that service quality can directly and indirectly effect customer 
satisfaction, and that satisfaction has a direct effect on bank customer loyalty. The reason is that customers' expectations on key service attributes, and each new service experience, combine to form an evaluation of service and this affects what customers believe will and should occur in future service encounters (Parasuraman et al., 1994).

In regards to bank customers' switching behaviour, high service quality is essential in order to prevent customers from leaving their current bank. Berggren \& Dewar (1991) investigated the United Stated banking industry in 1990 and found $42 \%$ of consumers closed an account or switched to another institution as a result of service-related problem. Furthermore, Levesque \& McDougall (1996) point out that service problems and the bank's service recovery ability have a major impact on customer satisfaction and customers' intentions to switch banks.

In respect to the Asian financial market, Dusuki \& Abdullah (2006) study the main factors that motivate customers to select Islamic banks in Malaysia. Their results show that the service quality of Islamic banks contributes to customer satisfaction, and influences customers' support for Islamic banking.

\subsubsection{Service Products}

Service products are an important component of service quality in intangibly based services as identified in several studies focusing on the hierarchical nature of service quality. Service products can be components of interaction quality, physical environment quality, and outcome quality in a hierarchical context (Dagger, Sweeney \& Johnson, 2007; Clemes et al., 2007). For example, access and service portfolio are a component of service quality in Bahia \& Nantel's (2000) study in retail banking. 


\subsection{Service Products Characteristics}

In the context of commercial marketing, product considerations include the actual product or service as well as the brand name, reputation, and packaging. Rushton \& Carson (1989) conclude that products based on goods tend to have more tangible characteristics, and products based on services tend to be more intangible. Service products normally include a core service, which associates with specific features, service specifications, and targets (Rushton \& Carson, 1989; Rust \& Oliver, 1994).

\subsection{The Importance of Service Products}

In a technology-driven, fast-paced environment, delivering a wide range of products to customer is essential for businesses' success and survival (Strieter, Gupta, Raj \& Wilemon, 1999). Today's competition is not only between organisations, but also between products. Easingwood \& Storey (1995) state that one of the more important business development strategies is the introduction of successful new products. Service products associated with technologies can reduce transaction costs, switching rates, and encourage customers to create services outcomes on their own (Bitner, Ostrom \& Meuter, 2002).

Delivering a broad range of service products is very important in the banking industry because of the intensive competition between financial and non-financial institutions. Dixon (1999) suggests that a key determinant in attracting customers is the diversity of features of service products introduced to the marketplace via different technology mediums. Stewart (1998) reveals that it is necessary for banks to offer certain types of financial products, such as 24 hours ATM self-service, phone, and internet banking. These developments provide customers with unlimited access to financial service products and offer them a wider range of choices than before (Gonzalez \& Guerrero, 
2004). Gerrard \& Cunningham (2004) conclude that service products combined with high technology can attract the customers who are techno-seekers to the more innovated banks, which offer a quick, convenient, and higher quality service. Alternatively, the less innovated banks which cannot offer these types of delivery method effectively may cause customers to switch banks.

\subsubsection{Effective Advertising Competition}

In an era of mature and intense competitive pressures, effective advertising can broaden the communication channel between customers and institutions which enhances the chance of success. According to Cengiz, Ayyildiz \& Er (2007), advertising refers to activities undertaken to increase sales or enhance the image of a service, firm or business, and the primary purpose of advertising is to inform the potential customer of the characteristics of products or services.

Dunn (1995) states that adverting plays an important role in attracting customers to the business in the beginning stage, and maintaining customer traffic levels during slow periods. Rust \& Zahorik (1996) show similar results where advertising can improve utilisation during slow periods as it may offer opportunities to educate customers about businesses' service characteristics and operation process which can increase productivity from existing technical capacity. Davies (1996) explains that advertising can strength the communication between organisations and customers, and effectively reduces consumers' perceived risks. Furthermore, advertising can affect customers' behaviour because it can provide information to guide customers' purchasing decisions. According to Hite \& Faster (1988), professional services advertising including bank advertising can change customers' attitudes and perceptions toward the service provided. Similarly, Cengiz et al. (2007) study bank 
customer behaviour in Turkey and find that efficient advertising could enhance a bank's customer loyalty and help retain customers.

However, Blanchard \& Galloway (1994) argue that advertising could produce a sterile image. Advertising may reinforce similarity of financial service providers rather than the differences (Balmer \& Stotvig, 1997; Blanchard \& Galloway, 1994). Effective advertising competition may stimulate switching because bank customers have been informed about more opportunities for their purchasing choices (Balmer \& Stotvig, 1997).

\subsubsection{Involuntary Switching}

Switching behaviour is caused not only by distinct decision, but also by involuntary factors not related to the distinct decision (Roos, 1999). Keaveney (1995) describes the factors beyond the control of either customers or the service providers as involuntary switching factors. Customers may switch unintentionally, such as by moving house, changing jobs, or branches being closed in their resident area. Therefore, relocation or other factors that are beyond the control of customers or service providers can destroy even the most satisfied service relationship (Taylor, Roos \& Hamer, 2009). In addition, Friedman \& Smith (1993) and Ganesh, Arnold \& Reynolds (2000) note that involuntary or unavoidable switches represent the most common switching behaviour in their studies.

\subsubsection{Distance}

Convenient location is a critical factor influencing customers' evaluation about firms' performance (Levesque \& McDougall, 1996). Keaveney's (1995) explains that a service provider's location is an important factor influencing switching behaviour 
under the inconvenience category. Customers tend to switch to a new provider if the new provider is closer to their work or home.

Location has special meaning in the financial service industry because it is at the branch or office that banks and the customer are connected; it is where the customers have their accounts (Peppard, 2000). Levesque \& McDougall (1996) suggest that a convenient bank location is an important factor influencing customers' switching behaviour because it directly determines whether the customers can access their banks on a regular basis. Gerrard \& Cunningham (2000) investigate the bank switching behaviour of Singapore's graduates and find that inconvenience is the most important switching factors. However, Peppard (2000) argues that location is irrelevant in the current e-business environment because more and more customers are using internet banking.

\subsubsection{Switching Cost}

Switching cost is a catch-all phrase to describe the variety of costs, both financial and non-financial, occurred in changing suppliers (Matthews \& Murray, 2007). Lee \& Cunningham (2001) demonstrate that a customer's loyalty can be determined not only by the costs which arise from dealing with the service provider, but also those costs from switching to another provider. Fornell (1992) added switching costs to customer satisfaction in the customer loyalty function.

Switching cost is categorised in different ways by many researchers. For example, Fornell (1992) summarizes switching costs into search costs, transaction costs, learning costs, loyal customer discounts, and emotional costs. Similarly, Dick \& Basu (1994) describe switching costs in terms of time, monetary, and psychological costs. Switching costs also include perceived risk which can be interpreted as customers' 
perception of the uncertainty and adverse consequences of buying a product or service (Dowling \& Staelin, 1994). In regards to the perceived risks of switching, Murray (1991) summarised six components: financial, performance, social, psychological, safety, and time/convenience loss. Recently, Matthews \& Murray, (2007) divide switching costs into three types: procedural switching costs indicating the expenditure of time and effort; financial switching costs measuring the loss of financially quantifiable resources, and relational switching costs reflecting psychological and emotional discomfort.

In the banking context, Matthews \& Murray (2007) interpret switching costs as the range of costs that bank customers incur if they wish to transfer their banking relationship, in part or in full, from one financial institution to another. Kiser (2002) states that switching costs for bank customers may include the time necessary to open a new account, close an old account, and notify parties with whom automated payments occur.

\subsubsection{The Importance of Switching Costs}

Many researchers have investigated relationships between switching costs and customers' switching behaviour. For example, Fornell (1992) states that switching costs can prevent switching behaviour by making it costly for customers to change service providers. These costs discourage customers to leave the current organisation because customers may perceive switching costs to be higher than the expected benefits of changing service providers (Lees et al., 2007). Gronhaug \& Gilly (1991) note that a dissatisfied customer may choose to stay if switching costs are too high. Investing effort, time and money changing service providers can act as significant barrier to a consumer taking action when dissatisfied with the current service provider. 
Therefore, Hauser, Simester \& Wernerfelt (1994) conclude that consumers become less sensitive to satisfaction level when switching costs are high. Colgate \& Lang (2001) investigate the switching barriers in the New Zealand financial industry and find that switching costs play an important role in forcing customers not to switch, even though they have seriously considered doing so. Anderson \& Sullivan (1993) show similar results in the airline and banking industries.

\subsubsection{Demographic Characteristics}

Customers with different demographic characteristics can act differently under the same situation. According to Block \& Roering (1976), demographic factors have been regarded as a basis for understanding customer characteristics and behaviour in the marketing area. Customers' demographic characteristics can be categorised as age, income, education, culture, or nationality (Au et al., 2001). These characteristics can contribute to a variety of customers' thresholds or tolerance levels which can affect customers' repurchase behaviour (Mittal \& Kamakura, 2001).

\subsection{Chapter Summary}

This chapter discussed customer switching behaviour in the retail banking industry. The literature supports the contention that price, reputation, service quality, service products, effective advertising competition, involuntary switching, distance, switching costs, and demographic characteristics can influence customers' switching behaviour. Despite a growing awareness of the factor that may influence customers' to switch banks among academic and practitioners, there are still research gaps in the literature. These gaps are outlined and discussed in the next chapter. The theoretical model for customers' switching behaviour and the hypotheses are also discussed. 


\section{Chapter 3 Conceptual Gaps and Research Hypotheses}

\subsection{Introduction}

This chapter provides a summary of the research gaps identified in the customers' switching behaviour literature in Chapter Two. The research objectives are identified in the following section. In addition, the 15 hypotheses proposed in this study are discussed. Finally, the theoretical research model of customers' switching behaviour is presented.

\subsection{Conceptual Gaps in the Literature}

The literature review has identified three research gaps in customers' switching behaviour in the Chinese retail banking industry. These are:

1. Limited published research on the factors influencing customers' switching behaviour in the Chinese banking industry.

2. Limited published research in academic marketing journals focusing on customers' switching behaviour in the Chinese retail banking industry.

3. Limited empirical research on customers' switching behaviour in the Chinese retail banking industry.

\subsection{Hypotheses Development}

Based on the research gaps identified above, 15 hypotheses are developed to answer the following four research objectives:

(1) To identify the factors that influence customers' switching behaviour in the Chinese retail banking industry; 
(2) To determine the most important factors that influence customers' switching behaviour in the Chinese retail banking industry;

(3) To determine the least important factors that influence customers' switching behaviour in the Chinese retail banking industry;

(4) To determine the impact of the demographic characteristics on customers' switching behaviour in the Chinese retail banking industry.

\subsection{Hypotheses and Constructs Relating to Objective One, Two and}

\section{Three}

\subsubsection{Price}

The loyalty-switching transition can be affected by changing price perceptions (Varki \& Colgate, 2001). Keaveney (1995) finds that approximately thirty percent of the customers surveyed had switched firms due in part to poor service price perceptions. According to Martins \& Monroe (1994), customers tend to focus on the fairness of price, especially on price increases. Any price increases that are perceived as unfair by customers may result in switching actions (Camplbell, 1999). In general, it can be concluded that unfavourable price perceptions can affect customers' intention to switch (Campbell, 1999).

In the banking industry, Gerrard \& Cunningham (2004) suggest that price plays a more influential role in influencing customers' switching behaviour compared with service failures and inconvenience. The authors reveal that imposing higher charges on customers, or increasing fees, can have opposite effects, such as encouraging outward switching and discouraging inward switching. In addition, Dawes (2004) 
shows that there is a positive relationship between price increases and defection rates in the banking industry. Therefore, the following hypothesis is proposed:

H1: There is a positive relationship between an unfavourable perception of price and customers' switching banks.

\subsubsection{Reputation}

In the financial service industry, a positive reputation can increase customers' trust of the invisible purchase and enable customers to better visualize and understand intangible products (Berry, 2000). Weigelt \& Camerer (1988) comment that positive reputation acts as an important strategy tool to be utilized by a firm to earn aboveaverage profits. In respect to the banking industry, Wang et al. (2003) suggest that a bank's reputation plays a critical role in determining the purchasing and repurchasing behaviour of customers. Similarly, Yue \& Tom (1995) and Javalgi et al. (1989) demonstrate that bank customers' selection decisions can be affected by a bank's reputation. A good reputation can strengthen customers' trusts and confidences in a bank, while an unfavorable reputation can increase the probability of customers' decision to switch banks. Therefore, the following hypothesis is proposed:

$\mathrm{H} 2$ : There is a positive relationship between unfavourable bank reputation and customers' switching banks.

\subsubsection{Service Quality}

Service quality, as discussed in Chapter Two, is defined as the difference between customers' expectations of service to be received and perceptions of the service actually received (Parasuraman et al., 1988; Gronroos, 1984a). According to Lee, Lee \& Yoo's (2000) study, service quality can influence purchase intention across several 
industries including banks. Lewis \& Soureli (2006) investigate the antecedents of customer loyalty in retail banking and summarize that service related factors, such as speed of delivery, efficiency, friendliness, ease of contact and frequent communication can favorably assist banks to enhance customer loyalty. The authors' study reveals that the customers who perceived higher standards of service quality than their expectations are normally satisfied and appear to be loyal toward the bank.

Leeds's (1992) study shows that nearly half of the customers switch banks because of poor services. In addition, Leeds also shows that improving service quality can reduce customers' defection. Similar research by Zeithaml et al. (1996) confirms that unfavourable behavioural intentions can be determined by poor service quality. Mavri \& Loannou (2008) investigate customers' switching behaviour in Greek banking services and find that the quality of the offered banking products and services has a positive effect on decreasing switching behaviour. Therefore, the following hypothesis is proposed:

H3: There is a negative relationship between good service quality and customers' switching banks.

\subsubsection{Effective Advertising Competition}

Using advertising as a means of communication by financial service providers is still a debatable issue (Barchard, 1990). Many researches have focused on marketing strategies rather than pure advertising. Consequently, there is limited research on the financial service industry regarding the relationship between consumer switching behaviour and advertising. However, based on previous studies, effective advertising can add value, capture the attentions of the customers, and enhance customers' loyalty (Cengiz et al., 2007; Hite \& Fraster, 1988). Furthermore, professional service 
advertising is positively associated with customers' expectation of benefits and guides their purchasing behaviour. Therefore, the following hypothesis is proposed:

H4: There is a negative relationship between ineffective advertising competition and customers' switching banks.

\subsubsection{Involuntary Switching}

Several researches have demonstrated that switching behaviour can be affected by involuntary switching factors, such as moving house, or opening and closing bank branches in the resident area (Ganesh et al., 2000; Keveney, 1995; Friedman \& Smith, 1993). According to Keaveney (1995), approximately 6 percent respondents switched service providers for involuntary or unavoidable reasons. Although firms may provide a perfect service and meet their customers' requirements, firms can still lose customers due to reasons beyond the control of either party (Taylor, Roots \& Hamer, 2009). Therefore, the following hypothesis is proposed:

H5: Involuntary switching factors affect customers' switching banks.

\subsubsection{Distance}

Distance is another important factor in guiding customers to choose banks. Kiser (2002) concludes that location is critical matter for households choosing depository institutions due to the limited geographical accessibility of alternative banks. Gerrard \& Cunningham (2004) illustrate that geographical inconvenience has a negative impact on customers who want their banking services to be delivered on a face-to-face, personal basis. In contrast, a convenient location can encourage customers to stay at their current bank and delay the idea of switching, even if the satisfaction rate is not high (Lee \& Cunningham, 2001). Therefore, the following hypothesis is proposed: 
H6: There is a negative relationship between a favourable perception of distance and customers' switching banks.

\subsubsection{Switching Costs}

In today's competitive environment, customers have to face a trade-off between costs and benefits received. For high switching costs, dissatisfied customers may remain "loyal" because the alternative service providers require customers to invest effort, time and money, which can act as barriers to switching (Gronhaug \& Gilly, 1991). Alternatively, satisfied customers can be disloyal if low switching costs make switching relative easy (Jones \& Sasser, 1995).

Johns, Mothersbaugh \& Beautty (2002) investigate the relationships between switching costs and outcomes such as customer retention by using correlation analysis. The authors' results show that switching costs are positively and significantly related to repurchase intention. In the banking industry, switching costs can be interpreted in terms of money, time, and effort, such as transferring funds, opening a new account, and registering for online banking systems. These switching barriers are seen as one of the reasons that inhibit customer switching behaviour. Therefore, the following hypothesis is proposed:

H7: There is a negative relationship between high switching costs and customers' switching banks. 


\subsection{Hypotheses Related to Research Objective Four}

\subsubsection{The Demographic Characteristics Factors}

Many researchers have demonstrated that customers' demographic characteristics can be used to distinguish the behaviour of one segment of customers from another segment (Ratchford, 1999; Siles, Robinson \& Hanson, 1994). Ratchford (1999) concludes that younger customers are more likely to search for information and switch brands than older customers. Younger customers are at a stage in their life cycle that requires investments in consumption knowledge, while older consumers tend to be more loyal to a brand due to their accumulated investments in brand specific knowledge (Mittal \& Kamakura, 2001).

The customers' segmentation characteristic can also influence their bank switching behaviour. For example, Fry, Shaw, Lanzenauer \& Dipchand(1973) reveal that Canadian female graduates tend to switch banks more than male graduates. However, Siles et al. (1994) show that customers in the United States with different educational backgrounds shared the same behaviour in switching banks. Colgate \& Hedge (2001) demonstrate that switching tends to occur more frequently among younger males after investigating bank customers' behaviour in Australia and New Zealand. The authors report that bank switching is more common among younger customers, high-income, and highly educated customers than older, low-income and less-educated customers. In China, the people who work as business professionals have gained particular social prestige and can be grouped as white collar (Duthie, 2005). In general, the white collar group tend to switch banks because they earn high incomes and have a higher educational background (Li, 2008; China Daily, 2007; Duthie, 2005). 
Therefore, the following hypothesis is proposed:

H8: There is a positive relationship between younger age and customers' switching banks.

H9: There is a negative relationship between old age and customers' switching banks.

H10: There is a positive relationship between high income and customers' switching banks.

H11: There is a negative relationship between low income and customers' switching banks.

H12: There is a positive relationship between higher education levels and customers' switching bank.

H13: There is a negative relationship between lower education levels and customers' switching banks.

H14: There is a positive relationship between white-collar occupations and customers' switching banks.

H15: There are different perceptions of the switching factors between demographic groups.

As a result, 15 hypotheses were formulated and the theoretical research model is presented in Figure 1. 


\subsection{The Theoretical Research Model}

Figure 1
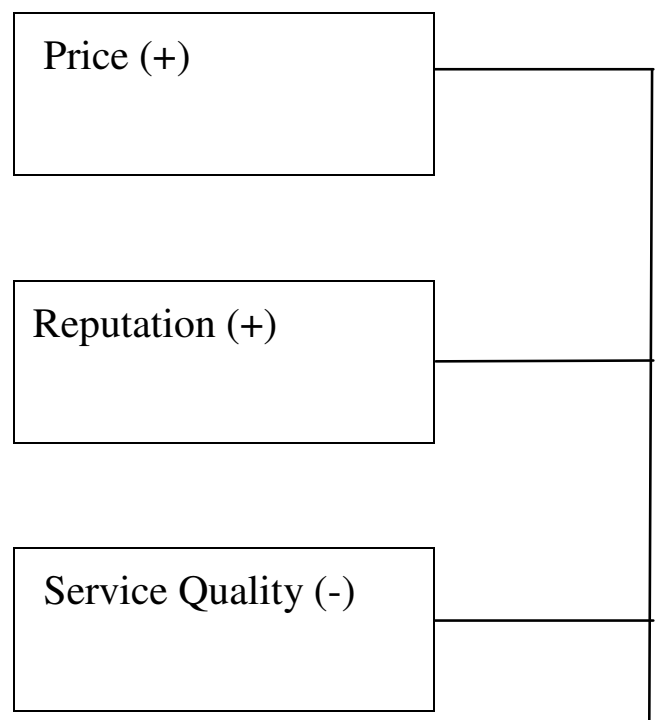

\section{Effective Advertising Competition(-)}

\section{Involuntary \\ Switching(+/-)}

\section{Distance (-)}

Switching Costs (-)

Demographic

Characteristics (+/-)
Switching

Behaviour

$\underline{\text { Binary Variable }}$

$1=$ Switch bank

0=Did not switch bank

Independent Variables 


\subsection{Chapter Summary}

This chapter identified three gaps in the customers' switching behaviour literature and discussed the major factors affecting customers switching behaviour in the retail banking industry. 15 hypotheses were formulated and the theoretical research model was presented. The methodology used to satisfy the research objectives will be discussed in Chapter Four. 


\section{Chapter 4 Research Methodology}

\subsection{Introduction}

This chapter outlines the research methodology used to test the 15 hypotheses developed in Chapter Three, and to satisfy the four research objectives stated in Chapter One and Three. The research plan includes sampling method, estimating sample size, method of data collection, and questionnaire design. Finally, factor analysis and logistic regression analysis are discussed.

\subsection{Sampling Method}

The lack of published research in the Chinese banking industry that focus on customers' bank switching behaviour made it necessary to collect primary data to test the 15 hypotheses and satisfy the four research objectives. The primary data was collected through a survey questionnaire. The sample was drawn from bank customers in Jiaozuo city, Henan Province of China to examine the factors affecting their bank switching behaviour. The data was collected from a convenience sample of individuals, irrespective of their banking purpose, gender, occupation or income. Respondents aged less than 18 years were excluded from the survey, as it was perceived they might have encountered difficulties interpreting the survey questions.

\subsection{Sample Size}

In order to make generalisations with confidence about the constructs under investigation, the appropriate sample size has to be considered. According to Sekaran (2003), sample statistics need to be reliable and represent the population parameters as 
closely as possible with a narrow margin of error. For factor analysis, the minimum sample size should be at least five times the number of variables to be analysed (Hair, Black, Babin, Anderson \& Thatham, 2006). Since there are 29 variables to be analysed in this study, at least 145 completed questionnaires were required.

For multiple regression analysis, Garson (2006) recommends that the sample size should be at least equal to the number of independent variables plus 104 for testing regression coefficients, and at least 8 times the number of independent variables plus 50 for testing the R-square respectively. Therefore, the 8 independent variables in this study require at least 114 completed questionnaires in order to test the regression coefficients and the R-square. However, the actual number of independent variables can only be derived from the factor analysis (Hair et al., 2006).

Furthermore, Crouch's (1984, p. 142) recommends that "minimum sample sizes for quantitative consumer surveys are of the order of 300 to 500 respondents". Therefore, this study required useable responses of at least three hundreds.

\subsection{Questionnaire Development}

In order to analyse customers' switching behaviour in the Chinese retail banking industry, a questionnaire was designed. The questionnaire was developed based on the findings from the literature review and feedback from the focus groups. As the nature of this research is exploratory, a thorough review of the literature and the focus group discussion helped to identify the customers' choice criteria for switching banks.

\subsubsection{Construct Operationalisation}

The literature review discussed in Chapter Two identified the potential primary factors affecting customers' switching behaviour in the Chinese retail banking industry. 
However, in order to develop additional insights into the factors affecting bank customers' switching behaviour, it was necessary to conduct focus group interviews. Focus group discussions were also used to assist in developing the appropriate and relevant survey questions.

Focus group research has been used to "review consumers' hidden needs, wants, attitudes, feelings, behaviours, perceptions, and motives regarding services, products, or practices" (Hair, Bush \& Ortinau, 2000, p.223). Furthermore, Greebbaum (1998) notes that focus group interviews are the most popular method for attitude research. Integrating focus group interviews with quantitative methods can be regarded as significant for developing and creating reliable measurement scales (Hair et al., 2000).

Following Greenbaum's (1998) recommendation, the researcher used two mini focus groups with 6 in each group. From the perspective of homogeneity recommended by Hair et al. (2000) in focus group research, the first group in this study consisted of six Chinese overseas students studying in New Zealand; and the second focus group consisted of six Chinese immigrants living in New Zealand.

The participants were asked to explain the factors that influenced them to switch banks. In addition, the groups were required to identify the most important factor that influenced their switching decisions. During the discussion, they were encouraged to identify any additional factors and provide comments on any factors suggested by other participants. The whole interview process was recorded and transcribed, and combined with the finding from the literature review to assist in the design of the questionnaire. 


\subsubsection{Questionnaire Format}

The questionnaire consists of four sections using a summated rating method, which required respondents to circle the number that most accurately reflects their perception of each statement (See Appendix 2). The respondents were asked to evaluate their overall experiences in switching banks. The first section asks whether the customers have switched banks in the last three years. Section Two focuses on bank customers switching experiences. Section Three addresses questions relating to non-switching bank customers' experiences with their current bank. The last section investigates customers' demographic information, such as gender, age, education level, occupation, and income. The original questionnaire was translated into Chinese using the tri-language translation (English to Chinese and Chinese to English).

The design of the questionnaire was based on multiple-item measurement scale. A seven-point Likert scale was adopted because the scale is the optimum size compared to five and ten point scales (Schall, 2003). Respondents were asked to assess the items of various constructs (such as price, reputation and service quality) on the seven-point Likert scale. The descriptors ranged from 1 (strongly disagree) to 7 (strongly agree).

\subsubsection{Pre-testing Procedures}

A pre-test of a survey questionnaire is necessary to assess its reliability and validity (Cooper \& Schindler, 2006). A pre-test was conducted from a random sample of 30 Chinese bank customers, aged 18 years and over. The respondents were encouraged to make comments on any questions that they thought were ambiguous or unclear. Some minor wording modifications to the questionnaire were made as a result of this process. A final version of the questionnaires is in Appendix 2 of this study. 


\subsection{Data Collection Procedures}

A total of 700 questionnaires were randomly distributed to respondents in the shopping mall rest areas during business hours ( 9 am to $5 \mathrm{pm}$ ) over a period of three weeks. The questionnaires were collected immediately upon completion. According to Zhou (2004), the use of an intercept survey has the advantage of immediate retrieval and capturing of customers' experiences with the participating banks. Given the specific focus of this study, the exit intercept method was deemed to be most effective. After explaining the purpose of the survey and obtaining consent, the respondents were asked to fill out the questionnaire. In general, most respondents were willing to assist in this survey and express their experiences with bank switching.

\subsection{Data Analysis Technique}

For the first research objective, exploratory factor analysis was used to determine the factors that contributed to switching behaviour. Subsequently, a logit regression analysis was used to test the conceptual model and the 15 hypotheses. Sensitivity analysis was performed to satisfy Research Objective Two and Three. The marginal effect method ranked the factors that influenced customers' switching behaviour from the most important to least important. The last research objective was addressed by using T-tests and ANOVA.

\subsubsection{Factor Analysis}

Factor analysis is a multivariate statistical method whose primary purpose is to define a structure within a set of observed variables (Stewart, 1981). It is an interdependence technique in which all variables are simultaneously considered (Hair et al., 2006). Stewart (1981) summarises three functions of factor analysis: (1) minimising the 
number of variables while the amount of information in the analysis is maximised; (2) searching qualitative and quantitative data distinctions when the data is too large: (3) testing hypotheses about the number of distinctions or factors underlying a set of data.

The following sections discuss different types of factor analysis, the assumptions of factor analysis, factor rotation, and interpretation of the resulting factors.

\subsubsection{Modes of Factor Analysis}

There are numerous factor analysis modes (see Table 4.1), and all factor modes provide information about the dimensional structure of the data (Stewart, 1981). According to Hair et al. (2006), the selection of the appropriate mode is based on the objective of the research. In this study, the objective is to factor a set of variables collected from a number of individual items. Therefore, $\mathrm{R}$ factor analysis is appropriate and can be used in this study to identify latent dimensions (Hair et al., 2006).

Table 4.1 Modes for Factor Analysis (Stewart, 1981, p. 53)

\begin{tabular}{|c|c|c|c|}
\hline Technique & $\begin{array}{l}\text { Factors are loaded } \\
\text { by }\end{array}$ & $\begin{array}{l}\text { Indices of } \\
\text { Association are } \\
\text { computed across }\end{array}$ & Data are Collected on \\
\hline $\mathrm{R}$ & Variables & Persons & One Occasion \\
\hline Q & Persons & Variables & One Occasion \\
\hline S & Persons & Occasions & One Variable \\
\hline $\mathrm{T}$ & Occasions & Persons & One Variable \\
\hline $\mathrm{P}$ & Variables & Occasions & One Person \\
\hline $\mathrm{O}$ & Occasions & Variables & One Person \\
\hline
\end{tabular}

\subsubsection{Types of Factor Analysis}

Factor analysis techniques can be achieved from either an exploratory or confirmatory perspective (Hair et al., 2006). Exploratory factor analysis is normally used when the 
underlying dimensions of a data set are unknown. Confirmatory factor analysis is appropriate for theory building by testing hypotheses about the structure of a data set that has been formed by prior research (Stewart, 1981). Due to the unknown nature of the data structure in this study, exploratory factor analysis was adopted.

Exploratory factor analysis has two basic models to obtain factor solutions: common factor analysis and component factor analysis (Hair et al., 2006). Choosing the appropriate model is dependent on the objectives of the factor analysis, and the amount of prior knowledge about the variance in the variables (Hair et al., 2006).

The common factor model is used when the objective is to identify underlying factors or dimensions that reflect what the variables share in common (Hair et al., 2006). While, component factor analysis is appropriate when the concern of the research is prediction, or the minimum number of factors is needed to account for the maximum portion of the variance, and when prior knowledge suggests that specific and error variance represents a relatively small proportion of the total variance (Hair et al., 2006). Due to the problematic and complicated nature of common factor analysis, component factor analysis was considered more appropriate for use in this study.

\subsubsection{Statistical Assumptions for Factor Analysis}

Hair et al. (2006) summarised several critical conceptual and statistical assumptions for factor analysis. The assumptions are:

No Selection Bias/Proper Specification. Factor analysis is a method to explore data whose structure is unknown. This method has means of determining the correlation among variable (Hair et al., 2006). Garson (2006) notes that the factors which are uncovered, can be significantly affected by any exclusion of relevant variables and the 
inclusion of irrelevant variables in the correlation matrix being factored. Thus, the priority issue for researchers is to ensure that the observed patterns are conceptually valid and appropriate to study using factor analysis (Hair et al., 2006).

Linearity. Factor Analysis is a linear procedure. Any non-linearity can bring a problematic solution (Coakes, Steed \& Price, 2008). Therefore, careful examination of any departures from linearity is necessary (Hair et al., 2006).

Normality. Examining normality is a necessary step in multivariate analysis. It must be determined whether differences are normally distributed between the obtained and the predicted dependent variable scores (Stewart, 1981). Any large variation from the normal distribution can bring an invalid solution (Hair et al., 2006).

Homoscedasticity. Factor analysis assumes homoscedasticity to the extent that the observed correlations are diminished (Hair et al., 2006).

Adequate Sample Size. Hair et al., (2006) suggests at least a 100 (or larger) sample size for performing factor analysis. In general, the minimum sample size is at least five times as many observations as there are variables to be analysed, and the preferred ratio is ten to one. In addition, a larger sample size is preferable to avoid the chance of the selected sample representing little generalsation (Hair et al., 2006).

However, the statistical assumption of linearity, normality, and homoscedasticity do not have to be met if the data matrix has sufficient correlation to justify the application of factor analysis (Hair et al., 2006). The methods to verify sufficient correlations for factor analysis are discussed in the following section. 


\subsubsection{Test for Determining Appropriateness of Factor Analysis}

According to Hair et al. (2006), there are several approaches to determine whether the correlation in the data set is sufficient for factor analysis.

Examination of the Correlation Matrix. It is a simple way to determine the appropriateness of a matrix for factoring. From the perspective of homogeneity, by using factor analysis, low correlation coefficients throughout the matrix may indicate that factoring is inappropriate (Stewart, 1981). According to Hair et al. (2006), factor analysis is only appropriate if visual inspection of the correlation matrix reveals a substantial number of correlations greater than .30 .

Inspection of the Anti-Image Correlation Matrix. The appropriateness of matrix for factoring can also be measured by inspection of the anti-image correlation matrix. An anti-image correlation matrix represents the negative value of the partial correlations (Hair et al., 2006). The partial correlation between pairs of variables should be small, and the correlation matrix should be near diagonal if the matrix is appropriate for factoring. Therefore, if the anti-image matrix has many non-zero off-diagonal entries, the correlation matrix is not suitable for factoring (Stewart, 1981).

Bartlett's Test of Sphericity. It is another statistical technique to test the appropriateness in the correlation matrix. The test provides the statistical probability that the correlation matrix has significant correlations among the variables (Hair et al., 2006). The hypothesis test is that the correlation matrix came from a population of variables that are independent. Rejection of the hypothesis indicates that the data are appropriate for factor analysis (Stewart, 1981). 
Kaiser-Meryer-Olkin Measure of Sampling Adequacy (MSA). This approach intends to quantify the degree of interrelations among the variables and the appropriateness of factor analysis (Hair et al., 2006). The index ranges from 0 to 1 , reaching 1 when each variable is perfectly predicted without error by the other variables (Hair et al., 2006). Kaiser and Rice (1974) summarised different levels of MSA: .90+ (marvelous); .80+ (meritorious); .70+ (middling); .60+ (mediocre); .50+ (miserable); and below .50 (unacceptable).

\subsubsection{Factor Extraction in Principle Components Analysis}

Hair et al. (2006) recommends that if there are a lager set of variables, factor extraction procedures should be started by extracting the combinations of variables that explain the greatest amount of variance. The extraction then proceeds to the combinations that account for the smaller amount of variance and so onwards. There are two common criteria used to determine the number of factors to extract. These include: (1) latent root criterion; (2) screen plot (Stewart, 1981).

\section{Latent Root Criterion}

The latent root criterion is the most commonly used technique to represent the amount of variance in the original variables that is associated with a factor (Aaker, Kumar, Day \& Lawley, 2005). Each variable contributes a value of 1 to the total eigenvalue (Hair et al., 2006). If the factors have latent roots or eigenvalues greater than 1 , they are considered significant. Any other factors with lower eigenvalues should be disregarded (Hair et al., 2006; Stewart, 1981). This method is most reliable if the number of variables in the factor analysis is between 20 and 50 (Hair et al., 2006). 
Scree Test Criterion. The scree test is used to identify the optimum number of factors and is applied by plotting the latent roots against the number of factors in their order of extraction, the shape of the resulting curve can determine the cut-off point (Hair et al., 2006). The procedure is summarised by Stewart (1981, p.58) as:

"A straight edge is laid across the bottom portion of the roots to see where they form an approximately straight line. The point where the factors curve above the straight line gives the number of factors, the last factor being the one whose eigenvalue immediately precedes the straight line."

\subsubsection{Factor Rotation}

Factor rotation is an important tool in interpreting factors. Factor loadings normally can be used to interpret the role each variable plays in forming each factor (Hair et al., 2006). Loadings reveal the degree of correspondence between the variable and the factors. The higher the factor loadings, the higher the degree the variable represents the factor (Hair et al., 2006). Basically, computation of a factor matrix can be rotated orthogonally or obliquely.

\section{Orthogonal rotation}

Orthogonal rotation is the simplest case of rotation, in which the axes are maintained at 90 degrees (Hair et al., 2006). Three major orthogonal approaches are: VARIMAX, QUARMAX, and EQUIMAX.

VARIMAX is the most common rotation procedure (Hair et al., 2006; Stewart, 1981), and intends to maximise the sum of variances of required loadings of the factor matrix (Hair et al., 2006). When the variable-factor correlation is closed to +1 or -1 , it can be interpreted as a clear positive or negative association; and when the correlation is 
closes to 0, it indicates a lack of association (Hair et al., 2006). QUARTIMAX is another orthogonal method, which focuses on rotating the initial factor so that a variable loads high on one factor and as low as possible on all other factors (Hair et al., 2006). The VARIMAX rotation was used in this study.

EQUIMAX method is combination of both the VARIMAX and QUARTIMAX methods. EQUIMAX tries to accomplish some simplification of factors and variables at the same time. However, this method has not been widely accepted and is used infrequently (Hair et al., 2006).

\section{Oblique Rotation}

Oblique rotation is similar to an orthogonal rotation, except that oblique rotations allow correlated factors instead of maintaining independence between the rotated factors (Hair et al., 2006). Stewart (1981) concludes that oblique rotations play an important role in assisting theory building, especially in the development of consumer behaviour theories. There are two common approaches for oblique rotation: OBLIMIN and PROMAX.

OBLIMIN is normally used when seeking a non-orthogonal solution. Applying OBLIMIN can lead to higher eigenvalues but diminished interpretability of the factors (Garson, 2006). PROMAS performs the similar function as OBLIMIN except computationally faster than OBLIMIN. Thus, PROMAS is more often selected when data sets are extensively large (Garson, 2008a).

The orthogonal rotation method has gained widespread acceptance in the marketing literature and very few factors are uncorrelated in reality (Hair et al., 2006). In many marketing application, correlated factors and hierarchical factor solutions are 
perceived to be intuitively attractive and theoretically justified (Stewart, 1981). Both oblique rotation and orthogonal rotation can be performed, particularly in exploratory research (Stewart, 1981). Therefore, along with the VARIMAX orthogonal rotation, an OBLIMIN oblique rotation was also used in this research.

\subsubsection{Interpretation of Factors}

When interpreting factors, decisions must be made regarding which factor loadings are worth considering. Sample size can determine the significance of factor loadings (see Table 4.2). Normally, the larger the absolute size of the factor loading requires more factor loadings in interpreting the factor matrix (Hair et al., 2006). Hair et al. (2006, p.129) summarise a few criteria for the significance of factor loadings:

- Although factor loadings of \pm .30 to \pm .40 are minimally acceptable, values greater than \pm .50 are generally considered necessary for practical significance.

- To be considered significant:

1. A small loading is needed given either a larger sample size or a large number of variables being analysed.

2. A larger loading is needed given a factor solution with a larger number of factors, especially in evaluating the loadings on later factors.

- Statistical tests of significance for factor loadings are generally conservative and should be considered only as starting points needed for including a variable for further consideration. 
Table 4.2: Guidelines for Identifying Significant Factor Loadings (Hair et al., 2006, p.128).

\begin{tabular}{cc} 
Factor Loading & Sample Size Needed for Significance \\
\hline 0.30 & 350 \\
0.35 & 250 \\
0.40 & 200 \\
0.45 & 150 \\
0.50 & 120 \\
0.55 & 100 \\
0.60 & 85 \\
0.65 & 70 \\
0.70 & 60 \\
0.50 & 50 \\
\hline
\end{tabular}

* Significance is based on .05 significance level and power level of 80 percent, and standard errors assumed to be twice those of conventional correlation coefficients.

Interpreting the complex interrelationship in a factor matrix is no simple matter as Hair et al., (2006) report that it is quite common that many variables have moderatesize significant loadings. The factor solution can only be obtained when all variables load on a factor (Hair et al., 2006). Therefore, the researcher needs not only to underline the highest loading for a variable, but also to continue to evaluate the factor matrix by underlining all significant loadings for a variable on all the factors.

\subsubsection{Summated Scale}

In order to reduce the over reliance on a single response and minimise measurement error, the summated scale technique is recommended by Hair et al. (2006). This technique is formed by combining all the variables loading highly on a factor and summing or averaging them to create a new variable (Hair et al., 2006). In addition, summated scales can present the multiple aspects of a concept in a single measure. According to Hair et al. (2006), the construction of a summated scale must consider content validity, dimensionality, and reliability. 


\subsubsection{Content validity}

Content validity is used to assess the correspondence between individual items and the concept (Hair et al., 2006). The objective is to ensure the selection of scale items include theoretical and practical considerations. A display of content validity indicates that the items are adequate and are representative of the concept they intend to measure (Churchill, 1979).

\subsubsection{Dimensionality}

Each summated scale should contain items that are unidmensional, meaning that they are strongly correlated with each other and present a single concept. To be regarded as unidimensional, each summated scale should consist of items that load highly on a single factor (Hair et al., 2006).

\subsubsection{Reliability}

Reliability can be used to assess the degree of consistency between multiple measurements of variables. Examining the internal consistency or homogeneity among the items is the common measurement of reliability (Cooper \& Schindler, 2006). According to Churchill (1979), Cronbach's Alpha is one of the most widely used measures to test internal consistency and is considered adequate if it exceeds 0.60. Churchill (1979) also notes that for the purpose of consistency, the coefficient alpha should be calculated prior to any further data analysis. Cronbach's alpha was applied in this study to test the reliability of the measures. 


\subsubsection{Logistic Regression Analysis}

After conducting the factor analysis and subsequently creating summated scales, the derived factors can be confirmed and used for statistical analysis. In this study, behavioural response - staying or switching banks, involves two qualitative choices. Therefore, a qualitative choice model is a valuable statistical analysis technique that can be applied to switching behaviour.

\subsubsection{Qualitative Choice Analysis}

Qualitative choice analysis is a common method used in interpreting decision-makers' choices in certain types of situation such as transportation, energy, housing, telecommunications and banking (Train, 1986). Discrete models are often used to denote the same thing as qualitative choice analysis. The construction of qualitative choice models in which the dependent variable takes on a dichotomous or polychotomous character, have been applied to economic, business and marketing analysis (Greene, 2003). Basically, qualitative choice models can determine the probability (or likelihood) that a decision maker will choose a particular alternative from a set of alternatives, given the data observed by the researcher (Train, 1986).

There is an increasing trend in using qualitative choice modelling in economic and behavioural research because of the existence of many discrete variables (Amemiya, 1981). For example, Ennew and Binks (1996) use a logit model to identify factors affecting bank customer retention and defection. Furthermore, Gan, Clemes \& Weng (2006) use a logit analysis to analyse consumers' choice of banking channels in New Zealand. The authors' results indicate that service quality dimensions, perceived risk factors, user input factors, occupation and education are important variables influencing consumers' choice of electronic banking. 
According to Train (1986, p.4), a qualitative choice situation is defined as one in which a decision-maker faces a choice among a set of alternatives which satisfy the following criteria:

a. The number of alternatives in the set is finite;

b. The alternatives are mutually exclusive; that is, the person's choosing one alternative in the set necessarily implies that the person does not choose another alternative; and

c. The set of alternative is exhaustive; that is, all possible alternatives are included, so the person necessarily chooses one alternative from the set.

Examples of choice situations meeting these criteria include a household's choice of type of convection oven (electric versus gas); a worker's choice of mode of travel to work (bus versus private car) (Train, 1986). In this study, whether an individual chooses to switch bank or stay with the current bank falls into the realm of qualitative choice (Gan et al., 2006). Qualitative choice models calculate the probability (or likelihood) that a decision-maker, with a given set of attributes, makes one choice rather than the alternative (Liao, 1994).

Any choice situation in which the decision or choice is represented by a continuous variable is not a qualitative choice situation. In general, qualitative choice models can designate a class of models, such as logit and probit, which attempt to relate the probability of making a particular choice to various explanatory factors and calculate the probability that the decision-maker will choose a particular choice or decision from a set of choices or decisions $\left(\mathrm{J}_{\mathrm{n}}\right)$, given data observed by the researcher. This 
choice probability $\left(\mathrm{P}_{\text {in }}\right)$ depends on the observed characteristics of alternative $\mathrm{i}\left(\mathrm{Z}_{\text {in }}\right)$ compared with all other alternatives $\left(Z_{j n}\right.$, for all $j$ in $J_{n}$ and $\left.j \neq i\right)$ and on the observed characteristics of the decision-maker $\left(\mathrm{s}_{\mathrm{n}}\right)$. The choice probability can be specified as a parametric function of the general form:

$$
P_{\text {in }}=f\left(Z_{\text {in }}, Z_{j n}, s_{n}, \beta\right)
$$

where $\mathrm{f}$ is the function relating the observed data to the choice probabilities specified up to some vector of parameters, $\beta$. By relating qualitative choice models to utility theory, a clear meaning of the choice probabilities emerges from the derivation of probabilities from utility theory. The utility from each alternative depends on various factors, including the characteristics of the decision-maker. By labeling the vector of all relevant characteristics of person $\mathrm{n}$ as $\mathrm{R}_{\mathrm{n}}$ and the vector of all characteristics of alternative $\mathrm{i}$ chosen by person $\mathrm{n}$ as $\mathrm{X}_{\text {in }}$, utility is a function of these factors,

$$
\mathrm{U}_{\text {in }}=\mathrm{U}\left(\mathrm{X}_{\mathrm{in}}, \mathrm{r}_{\mathrm{n}}\right)
$$

for all $\mathrm{i}$ in $\mathrm{J}_{\mathrm{n}}$, the set of alternatives.

Based on Marshall's consumer demand theory of utility maximisation, the decisionmaker therefore chooses the alternative from which he or she derives the greatest utility. The individual choice can be said to be deterministic, and he or she will choose $i\left(i \in J_{n}\right)$ if $U\left(X_{i n}, n_{r}\right) \geq U\left(X_{j n}, n_{r}\right)$, for $\left(i, j \in J_{n}\right.$ and $\left.j \neq i\right)$. To specify the choice probability in qualitative choice models, $U\left(X_{\text {in }}, n_{r}\right)$ for each $i$ in $J_{n}$ can be divided into two sub functions, a systematic component that depends only on factors that the researcher observes and another that represents all factors and aspects of utility that are unknown or excluded by the researcher, labelled in $\varepsilon$ in. Thus, 


$$
\mathrm{U}_{\text {in }}=\mathrm{U}\left(\mathrm{X}_{\text {in }}, \mathrm{n}_{\mathrm{r}}\right)=\mathrm{V}\left(\mathrm{Z}_{\text {in }}, \mathrm{n}_{\mathrm{s}}\right)+\varepsilon_{\text {in }}
$$

where in $\mathrm{Z}$ are the observed attributes of alternative $\mathrm{i}$ and $\mathrm{S}_{\mathrm{n}}$ are the observable characteristics of decision-maker $n$.

$$
\mathrm{P}_{\text {in }}=\mathrm{P}\left(\mathrm{U}_{\text {in }} \geq \mathrm{U}_{\text {jn }}\right) \quad \forall \mathrm{i}, \mathrm{j} \in \mathrm{J}_{\mathrm{n}} \text { and } \mathrm{i} \neq \mathrm{j},
$$

hence,

$$
\mathrm{P}_{\text {in }}=\mathrm{P}\left(\mathrm{V}_{\text {in }}-\mathrm{V}_{\text {jn }} \geq \varepsilon_{\text {jn }}-\varepsilon_{\text {in }}\right) \quad \forall \quad \mathrm{i}, \mathrm{j} \in \mathrm{J}_{\mathrm{n}} \text { and } \mathrm{i} \neq \mathrm{j}
$$

Qualitative choice models are used to estimate probabilities of choices being made, and they attempt to relate the probability of making a particular choice to various explanatory factors (Sellar, Chavas \& Stoll, 1982). Probabilities should be between zero and one. Estimation of parameters to maximise the probability of the choice $Y_{i}=$ 1 by use of a linear probability model and ordinary least squares (OLS) is not preferable because of the return of probabilities outside the unit interval (Stynes \& Peterson, 1984). Furthermore, the use of a linear probability model can lead to heteroscedastic errors and therefore, t-tests of significance are not valid (Miller \& Hay, 1981).Thus, it is acceptable to use either a logit or probit model.

Different qualitative choice models are obtained by specifying different distributions of the unknown component of utility, $\varepsilon_{\mathrm{in}}$, and deriving functions for the choice probabilities (Ben-Akiva \& Lerman, 1995; Train, 1986). If the error term is assumed to be Gumbel-distributed, then the above represents the standard binary logit model. While the model becomes the binary probit model if the error term is assumed to be normally distributed (Greene, 2003; Ben-Akiva \& Lerman, 1995). Due to the binary 
nature of the approach, and the differences between the two models are slight (Maddala, 2001), the logit model is be used in this research. The model is estimated by the maximum likelihood method used in LIMDEP version 7.0 software.

Thus, the choice probabilities can then be expressed as

$\mathrm{P}_{\text {in }}=\mathrm{e}^{\mu \mathrm{Vin}} / \sum_{\mathrm{j}} \in{ }_{\mathrm{jn}} \mathrm{e}^{\mu \mathrm{Vjn}} . \forall \mathrm{i}, \mathrm{j} \in \mathrm{J}_{\mathrm{n}}, \mu=$ positive scale parameter, i.e. $\mu>0$.

or,

$$
\mathrm{P}_{\text {in }}=1 /\left(1+\mathrm{e}^{-\mu[\text { Vin-Vjn }]}\right)
$$

The maximum likelihood estimator is consistent, asymptotically efficient ${ }^{1}$ and asymptotically normal ${ }^{2}$.

For example, consumers who are considering switching banks are faced with a simple binary choice situation; to switch to a new bank, or to stay with the current bank. The consumer's utility associated with switching bank is denoted as $\mathrm{U}_{1 \mathrm{n}}$ and the utility associated with staying with the current bank is denoted as $\mathrm{U}_{0 \mathrm{n}}$, which is represented as:

$$
\mathrm{U}_{\text {in }}=\mathrm{V}_{\text {in }}+\varepsilon_{\text {in }} \quad \forall \quad \mathrm{i} \in \mathrm{J}_{\mathrm{n}} \text { and } \mathrm{J}_{\mathrm{n}}=\{0,1\}
$$

The consumer will choose to switch to a new bank if $U_{1 n}>U_{0 n}$, and the utility of each choice depends on the vector of observable attributes of the choices and the vector of observable consumer characteristics, summarised as $V_{\text {in }}$. All unobservable

\footnotetext{
${ }^{1}$ Asymptotically efficient means that for large $n$, no other consistent estimator has a smaller variance.

${ }^{2}$ Asymptotically normal means that for large $n$, they closely approximate the normal distribution, even if the distribution from which the observations were drawn was not normal (Ramanathan, 1992).
} 
and excluded attributes and consumer characteristics are represented by the error term, $\varepsilon$ in, that is assumed to be independently and identically Gumbel distributed. The choice probability of $U_{1 n}>U_{0 n}$ is given as $P_{I n}=\operatorname{Pr}_{n}\left(U_{1 n}>U_{0 n}\right)=1 /\left(1+e^{-\mu[\text { Vin- }}\right.$ ${ }^{\mathrm{Vjn}]}$ ), where $\mu>0$. In a bank switching decision, the vector of observable consumer characteristics is represented in parametric functional form as follows.

SBANK $=\mathrm{f}(\mathrm{PR}, \mathrm{RP}, \mathrm{SQ}, \mathrm{EAC}, \mathrm{IS}, \mathrm{D}, \mathrm{SC}, \mathrm{DC}, \varepsilon)$

SBANK is the dependent variable which identifies whether an individual has switch or did not switch bank in the last 3 years. The dependent variable is based on the question asked in the survey: "Have you switched banks in the last three years?"

$\begin{array}{lll}\mathrm{SBANK} & = & 1 \text { if the respondent has switched bank; } 0 \text { otherwise; } \\ \mathrm{PR} & = & \text { Price; } \\ \mathrm{RP} & = & \text { Reputation; } \\ \mathrm{SQ} & = & \text { Effective Advertising Competition; } \\ \mathrm{EAC} & = & \text { Involuntary Switching; } \\ \mathrm{IS} & = & \text { Distance; } \\ \mathrm{D} & = & \text { Switching Costs; } \\ \mathrm{SC} & = & \text { Demographic Characteristics; } \\ \mathrm{DC} & = & \text { Error term. }\end{array}$


Demographic Characteristics:

GEN $(+/-)=\quad$ Dummy variables for gender
Gender $1 ; 1$ if respondent is a male; 0 otherwise

AGE $(+/-)=\quad$ Dummy variables for age group

Age Group 1; 1 if respondent is between 18 to 25 years old; 0 otherwise

Age Group 2; 1 if respondent is between 26 to 35 years old; 0 otherwise

Age Group 3; 1 if respondent is between 36 to 45 years old; 0 otherwise

Age Group 4; 1 if respondent is 46 years old and over; 0 otherwise

QUA $(+/-)=\quad$ Dummy variables for Education

Education 1; 1 if respondent completed low-level education (up to middle school certificate); 0 otherwise

Education 2; 1 if respondent completed medium-level education (high school certificate); 0 otherwise

Education 3; 1 if respondent completed medium high-level education (diploma qualification); 0 otherwise

Education 4; 1 if respondent completed high-level education (bachelors degree, postgraduate degree and above); 0 otherwise 
$\operatorname{OCC}(+/-)=$

$\operatorname{INC}(+/-)=$
Dummy variables for occupation

Occupation 1; 1 if respondent is white-collar (professional, selfemployed); 0 otherwise

Occupation 2; 1 if respondent is student (student, sales/services); 0 otherwise

Occupation 3; 1 if respondent is civil servant; 0 otherwise Occupation 4; 1 if respondent is blue collar (farmer, labour); 0 otherwise

Occupation 5, 1 if respondent is others (retired, unemployed, households, other); 0 otherwise

Dummy variables for monthly income level

Income 1; 1 if respondent has low-level income (e.g. under CNY 499); 0 otherwise

Income 2; 1 if respondent has middle-level income (CNY 500 2,999); 0 otherwise

Income 3; 1 if respondent has middle high-level income (CNY 3,000 - 5,999); 0 otherwise

Income 4; 1 if respondent has high-level income (CNY 6,000 and over); 0 otherwise

$\varepsilon=$ 


\subsubsection{Statistical Assumptions for Logistic Regression}

\subsubsection{Outliers:}

Outliers are observations that have large residual values, or an observation that is far removed from the rest of the observations (Hair et al., 2006). According to Dielman (2001), the presence of an outlier may have a large effect on the estimated regression line, and can at times produce confusing results and mask important information that could otherwise be obtained from the regression. Therefore, the outliers need be identified and deleted from the analysis if there is a reason to believe that other variables not in the model explain why the outlier observations are unusual (Garson, 2006). However, deletion must be done with care because deletion of some outliers often results in the generation of further outlying cases (Coakes et al., 2008).

\subsubsection{Linearity:}

Linearity refers to the relationship between the dependent and the independent variable that is usually represented by a straight line (Cohen, Cohen, West and Aiken, 2003). If the form of the relationship between the dependent and the independent variable is not properly specified, the estimates of both the regression coefficients and the standard errors may be biased.

The concept of correlation is based on a linear relationship (Hair et al, 2006) and the relationship can be examined through residual plots (Dielman, 2001). Cohen et al. (2003) summarise that examination of graphical displays can be used to test a linear relationship adequately characterises the data as they can detect a wide range of misspecifications of the form of the relationship. In a multiple regression with more 
than one independent variable, it is possible to show the combined effects of all predictor variables (Hair et al., 2006).

\subsubsection{Multicollinearity:}

Multicollinearity can have harmful effects on multiple regression and normally increases when the explanatory variables are highly inter-correlated, making the separate effects of each of the explanatory variables on the explained variable difficult to disentangle (Maddala, 2001). Hair et al. (2006) suggest the simple way to identify the collinearity between variables is to use the correlation matrix for the independent variables. If the Pearson's between each pair of the independent variables is at 0.80 or less, the correlation is acceptable (Bryman \& Cramer, 1999).

\subsubsection{Data Level:}

To apply binary logistic regression, some of the independent variables should be coded as dummy variables. According to Fox (1947), a dummy-variable can be a dichotomous (i.e., two-category) or a polytomous (many-category) independent variable. For example, more than two possible categories of behaviour (i.e. positive, neutral, or negative) are called polychotomous or ploytomous. In contrast, dichotomous situation can be defined if there is only two category (i.e., positive or negative).

\subsubsection{Sensitivity Analysis}

The sensitivity analysis was conducted in this study to answer Research Objective Two and Three. Studenmund's (2001) research recommends that Maximum Likelihood Estimates (MLE) can be used to estimate the logit model because it 
assumes large sample properties of consistency, efficiency, normality of parameter estimates, and validity of the t-test significance. Furthermore, many researchers suggest that the logit model avoids the major problem associated with Ordinary Least Square (OLS) estimation of the standard linear probability model (Hair et al., 2006; Judge, Hill, Criffiths, Lutkepoho \& Lee, 1982). The MLE coefficient estimates from the logit analysis have no direct interpretation with respect to the probability of the dependent variable $(\mathrm{Y}=1)$ other than indicating a direction of influence of probability (Hair et al., 2006; Judge et al., 1982).

Maddala (2001) finds that the magnitude of the marginal effect can be revealed from calculating changes in probabilities. This indicates the partial derivatives of the nonprobability function evaluation at each variable's sample mean (Liao, 1994; Pindyck

\& Rubinfeld, 1991). The marginal effect also represents the marginal change in the dependent variable, given a unit change in a selected independent variable, while holding other variables constant (Liao, 1994). Therefore, in order to rank the factors influencing customers to switch banks from the most to the least importance level, the marginal effect for each of the estimated coefficients was calculated.

\subsubsection{T-test and Analysis of Variance (ANOVA)}

T-test and Analysis of Variance (ANOVA) are the most common methods used in assessing group means. A T-test compares a dependent variable across two groups, and one way ANOVA is used when there are three or more groups (Hair et al., 2006). Hair et al. (2006) suggest the following assumptions in using the t-test and one-way ANOVA: 
(1) The data is assumed to be from a normally distributed population. The variances in each experimental condition are reasonably similar, outliers and high multicollinearity should not be present.

(2) The independent and dependent variables should be measured on an interval scale.

\subsubsection{T-test}

A T-test assesses the statistical significance of the difference between two independent sample means (Hair et al., 2006). The test of differences between two group means can be conceptualised as the difference between the means divided by the variability of random means. Hence, the $t$ statistic is a ratio of the difference between the two sample means to their standard error. In the case of the means for two independent samples, the hypotheses can be written in following form:

$\mathrm{H} 0: \mu_{1}=\mu_{2}$

$\mathrm{H} 1: \mu_{1} \neq \mu_{2}$

The formula for calculating the t-statistic value is:

T statistic $=\frac{\mu_{1}-\mu_{2}}{S E \mu_{1} \mu_{2}}$

where: $\mu_{1}$

$=\quad$ Mean of Group 1

$\mu_{2} \quad=\quad$ Mean of Group 2

$\mathrm{SE} \mu_{1} \mu_{2} \quad=\quad$ Standard error of the difference in group means. 
In this study, the results of t-tests can demonstrate whether or not the mean scores of two groups such as male and female, are significantly different with respect to switching behaviour.

\subsubsection{Analysis of Variance (ANOVA)}

Analysis of variance (ANOVA) is a statistical method used to test whether there is a difference between means of several groups (Dielman, 2001). In this study, ANOVA is conducted to test the demographic hypothesis for customers' perceptual differences of bank switching behaviour (eg. age, educational levels, occupation and income). The logic of an ANOVA test is to compare two independent estimates of the variance for the dependent variable, which is the general variability of respondents within the groups and the differences between groups (Hair et al., 2006).

1. $\mathrm{MS}_{\mathrm{w}}$ : Mean square within groups

2. $\mathrm{MS}_{\mathrm{B}}$ : Mean square between groups

Given that the null hypothesis of no group difference is not rejected, MS ${ }_{w}$ and MS ${ }_{B}$ represent the independent estimates of the population variance. Consequently, the ratio of $\mathrm{MS}_{\mathrm{B}}$ to $\mathrm{MS}_{\mathrm{w}}$ measures how much variance is attributable to different treatments versus the variance expected from random samplings, and is calculated as the follows (Hair et al., 2006):

$\mathrm{F}$ statistic $=\frac{\mathrm{MS}_{\mathrm{B}}}{\mathrm{MS}_{\mathrm{w}}}$

Although the F-tests of ANOVA evaluate the null hypothesis of equal means between groups, the results cannot identify where the significant differences lie if there are 
more than two groups (Hair et al., 2006). In order to identify the significant differences among groups, Hair et al. (2006) recommend five common post hoc procedures: the Scheffe test, the Turkey's honestly significant difference test, the Turkey's extension of the Fisher least significant approach, the Duncan's multiple range test, and the Newman-Kules test. The Scheffe test is the most conservative method to control Type I error among these procedures (Hair et al., 2006). As there are some demographic characteristics that include three or more groups (such as age, occupation, education and monthly income), it is appropriate to use the Scheffe test to test for significant differences among these groups.

\subsection{Chapter Summary}

This chapter outlined the research methodology used to test the 15 hypotheses developed in the Chapter Three, and to answer the four research objectives stated in Chapter One and Three. The expected sample size and sampling method were explained, including data collection methods. The questionnaire design, format, pretesting and data analysis techniques were also discussed. 


\section{Chapter 5 Results and Discussion}

\subsection{Introduction}

This chapter presents the results obtained from the data analysis and research methodology discussed in Chapter Four. The data set is used to examine the assumptions of factor analysis and logistic regression analysis. The results of factor analysis, logistic regression analysis, T-tests and ANOVA are presented, and the 15 hypotheses are tested. The results are discussed in terms of their relation to each of the relevant research objectives. The data was analysed using SPSS version 15 and LIMDEP version 7.

\subsection{Sample and Response Rate}

A total of 437 questionnaires were returned from 700 questionnaires distributed using the convenient sampling method. 26 questionnaires were eliminated from the data as they were incomplete, and therefore, not suitable for use in this study. This resulted in 421 completed useable questionnaires generating a $60.14 \%$ useable response rate.

The useable responses were above the minimum sample size of 145 as discussed in Chapter Four, Section 4.3. Furthermore, Sekaran (2003) and Crouch's (1984) recommend that the quantity of the useable questionnaires returned of between 300 and 500 are considered to be the appropriate size for most behavioural research. Therefore, the sample size was deemed acceptable for the purpose of this study. 


\subsection{Descriptive Statistics}

The data in Table 5.1 shows the descriptive statistics for the respondents who switched banks and those who did not switch banks. From the 421 useable questionnaires, 36.3\% (153) of the respondents switched banks during the last three years, while $63.7 \%$ (268) of the respondents did not switch banks. The sample respondents consisted of $51.5 \%$ males and $48.5 \%$ females. The dominant groups were aged between 26 to 35 years (46.8\%) and 36 to 45 years $(29.2 \%)$. The majority of the respondents had a Bachelor Degree (35.9\%) or a Diploma \& Certificated $(27.3 \%)$. In terms of occupation, the dominant groups were the respondents who worked as Civil Servant (19\%) and Professional \& Self-Employed (16.9\%). In addition, the major income levels of respondents were between CNY 500 - 2,999 (60.3\%) and CNY 3,000 $-5,999(18.3 \%)$.

When distinguishing respondents based on switching and non-switching behaviour, the 268 respondents who did not switch banks had similar demographic characteristics to the 153 respondents who switched banks in regards to gender and education. However, the age, occupation and income characteristics for respondents between switcher and non-switcher were different. The Young Age Group was more likely to switch banks than the Old Age Group (see Table 5.1). Furthermore, respondents with a high income (CNY 6,000 and above) had a higher probability to switch banks than consumers with a low income (under CNY 499). The majority of respondents who switched banks were Professional (24.2\%), whereas the majority of non-switching respondents were Civil Servants (20.5\%). 


\subsection{Assessment of the Data Set}

The data was tested to verify whether the statistical assumptions of factor analysis and logistic regression analysis had been met. The data was compromised of two groups of respondents: switchers and non-switchers. In order to apply factor analysis, the data from switching respondents was reverse coded and combined with the non-switching respondents' data.

\subsection{Statistical Assumptions for Factor Analysis}

In order to avoid the observed correlations between variables being diminished, the statistical assumptions of normality, homoscedasticity and linearity for factor analysis needed to be fulfilled. According to Hair et al. (2006), a data matrix that has sufficient correlation can be used to justify factor analysis. A series of statistical assumptions to test the data matrix include Examination of the Correlation Matrix, Inspection of the Anti-image Correlation Matrix, Barlett's Test of Sphericity, and the Kaiser-MeyerOlkin measure of sampling adequacy.

\subsubsection{Examination of the Correlation Matrix}

The correlation matrix (see Table 5.2) revealed that most of correlations were above .30 as recommended by Hair et al. (2006). The correlation matrix indicated that the data shared common factors and were therefore appropriate for factor analysis.

\subsubsection{Inspection of the Anti-Image Correlation Matrix}

The visual inspection of the off-diagonal elements of the anti-image correlation matrix (see Table 5.3) showed that the majority of these values were close to zero (absolute 
value less than 0.01 ). This result indicated that the data set was appropriate for factor analysis (Hair et al., 2006).

\subsubsection{Bartlett's Test of Sphericity}

Barlett's Test of Sphericity tests whether the correlation matrix comes from a population of variables that are independent. The test value (see Table 5.4) was high at 5993.329 and the level of significance was low 0.000. Therefore, the null hypothesis was rejected and the data set was deemed appropriate for factor analysis (Stewart, 1981).

\subsubsection{The Kaiser-Meyer-Olkin Measure of Sampling Adequacy}

The Kaiser-Meryer-Olkin Index measures values from 0 to 1 . In this research, the test results (see Table 5.4) was 0.854 , which can be defined as "meritorious" according to Kaiser \& Rice (1974), and therefore the data set was appropriate for factor analysis.

\subsubsection{Factor Analysis Results}

The results of the statistical assumptions tests indicated that data set was appropriate for factor analysis. Therefore, principle component factor analysis was conducted on all of the items that were consistent with information derived from the literature review and focus group interviews. The results were interpreted using the following criteria. 


\subsubsection{The Latent Roots Criterion}

Results of the latent root criterion reveal that seven factors were extracted from the 29 variables submitted for factor analysis (see Table 5.5). These seven factors explained $66.30 \%$ of the variation in the data.

\subsubsection{The Scree Test}

Figure 5.1 shows that by laying a straight edge across the bottom portion of the roots, these are seven factors before the curve becomes approximately a straight line. Therefore, this result indicates that the extraction of seven factors was appropriate for this analysis.

Figure 5.1

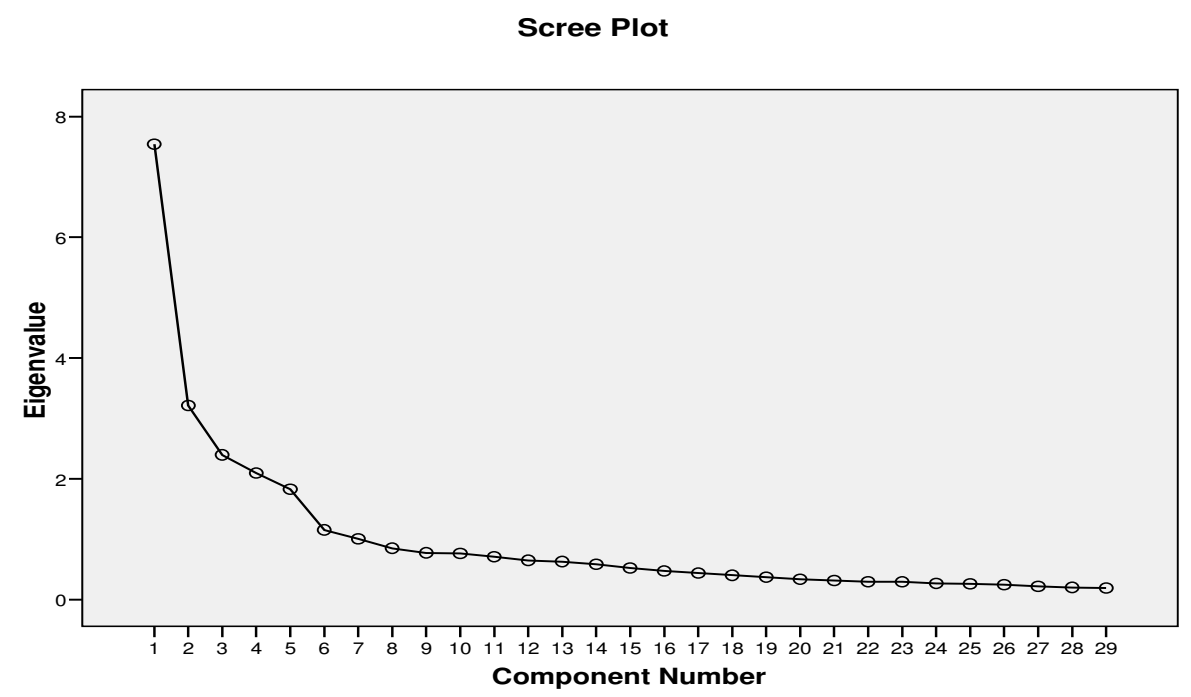

\subsubsection{Rotation Results}

Factor Rotation defined by Hair et al. (2006) simplifies the rows and columns of the factor matrix and maximise a variable's loading on a single factor in order to facilitate 
interpretation. An orthogonal rotation (VARIMAX) and an oblique rotation (OBLIMIN) are normally used to explain the computed factor matrix. In this research, both techniques showed similar factor loadings on most of the variables (see Table 5.6 and 5.7). Finally, a VARIMAX rotation was adopted as it produced a clearer structure in terms of the content validity of the factors.

\subsubsection{Factor Interpretation}

According to Hair et al. (2006), for a sample of 350 respondents, factor loadings of .30 and above are significant. However, the authors also suggest that values greater than \pm 0.50 are generally necessary for practical significance. Therefore, 0.50 was used as a cut-off point as \pm 0.50 resulted in an improved factor better structure and assisted in formulating the factor rotation. The results (see Table 5.6 and 5.7) show that all of the factors had significant loading above \pm .50 using the VARIMAX method. However, one variable (B12) was excluded from the factor structure. The remaining 28 variables were sorted into 7 factors (see Table 5.6), namely: (1) Price;

(2) Reputation; (3) Service Quality; (4) Effective Advertising Competition; (5) Involuntary Switching; (6) Distance; (7) Switching Costs.

\subsubsection{Assessment of Summated Scales}

Before summation of the items, the content validity, dimensionality and reliability of measurement scales were assessed.

\subsubsection{Content Validity}

Content validity subjectively assesses the correspondence between the individual items and the concept (Hair et al., 2006). Inspection of all the variables demonstrated 
that the selection of scale items were adequate and included theoretical and practical considerations. When applying the VARIMAX technique, all variables loaded on the seven sub-dimensions that were proposed in the research model. Therefore, it was concluded that the items exhibited adequate content validity.

\subsubsection{Dimensionality}

None of the variables cross loaded on any other factors (see Table 5.6).

\subsubsection{Reliability}

All the variables except B12 were subjected to reliability tests. The Cronach's Coefficient Alpha was used to test the reliability of each factor. In this study, all of the factors have a Cronach's Coefficient Alphas value greater than 0.60, as suggested by Churchill (1979) for exploratory research. The variables used in the summated scale and their Cronbach's Coefficient Alpha are summarised in Table 5.9.

\subsubsection{Statistical Assumptions for Logistic Regression Models}

There are numerous statistical tests to determine if the assumptions of logistic regression analysis were satisfied.

\subsubsection{Outliers}

Outliers are identified by Hair et al. (2006) as the observations that are substantially different from the other observations. The outliers were identified and removed from the analysis to reduce the effects of their influence on the regression analysis. 


\subsubsection{Multicollinearity}

The Pearson Correlation Matrix was used to inspect the correlations between the independent variables. The result (see Table 5.10) showed that the correlations were all below 0.80 , indicating no multicollinearity problems existed in the regression models used in this research.

\subsubsection{Data Level}

Due to the dichotomous nature of the dependent variable (switch or non-switch), binary logistic regression was used in this research (Garson, 2008b). All of the demographic items which were categorical characteristics were coded as dummy variables in the analysis.

\subsection{Results Pertaining to Research Objective One (Hypotheses 1}

\section{through 7)}

Research Objective One is to identify the factors that influence bank customers' switching behaviour. Logistic regression analysis was used to satisfy Research Objective One. The Table 5.11 shows the logistic regression results. All predicted influencing factors are statistically significant $($ Chi-Square $=220.0517, \mathrm{P}$ value $=$ 0.000, Degree of Freedom $=20$ ), and are summarised in Table 5.12. 
Table 5.12: The Logistic Regression Results for Influencing Factors

\begin{tabular}{|l|l|l|l|}
\hline Factors & B & S.E. & Sig. \\
\hline Price & 0.638296 & 0.1078 & $0.0000^{* *}$ \\
\hline Reputation & 0.292252 & 0.1318 & $0.0266^{* *}$ \\
\hline Service Quality & -0.34187 & 0.119 & $0.0041^{* *}$ \\
\hline Effective Advertising Competition & -0.21899 & 0.1065 & $0.0398^{* *}$ \\
\hline Involuntary Switching & -0.20429 & 0.1092 & $0.0615^{*}$ \\
\hline Distance & -0.33162 & 0.1021 & $0.0010^{* *}$ \\
\hline Switching Costs & -0.76398 & 0.1111 & $0.0000^{* *}$ \\
\hline Young Age Group & 1.72040 & 0.575 & $0.0028^{* *}$ \\
\hline White Collar Group & 1.21420 & 0.4461 & $0.0065^{* *}$ \\
\hline Other Occupations & 1.01244 & 0.4447 & $0.0228^{* *}$ \\
\hline Middle Income Group & 1.61341 & 0.5084 & $0.0015^{* *}$ \\
\hline Middle High Income Group & 2.66551 & 0.5906 & $0.0000^{* *}$ \\
\hline High Income Group & 3.24759 & 0.6926 & $0.0000^{* *}$ \\
\hline
\end{tabular}

Consequently, Hypotheses 1 to 7 are summarised in the following table

Table 5.13: Hypotheses 1 to 7 Test Results

\begin{tabular}{|l|c|c|}
\hline \multicolumn{1}{|c|}{ Hypotheses } & Supported & $\begin{array}{c}\text { Non } \\
\text { Supported }\end{array}$ \\
\hline $\begin{array}{l}\text { H1: There is a positive relationship between a } \\
\text { favourable perception of price and customers' } \\
\text { switching banks. }\end{array}$ & $\sqrt{ }$ & \\
\hline $\begin{array}{l}\text { H2: There is a positive relationship between } \\
\text { favourable bank reputation and customers' } \\
\text { switching banks. }\end{array}$ & $\sqrt{ }$ & \\
\hline $\begin{array}{l}\text { H3: There is a negative relationship between } \\
\text { poor service quality and customers' switching } \\
\text { banks. }\end{array}$ & $\sqrt{ }$ & \\
\hline $\begin{array}{l}\text { H4: There is a negative relationship between } \\
\text { effective advertising competition and } \\
\text { customers' switching banks. }\end{array}$ & $\sqrt{ }$ & \\
\hline $\begin{array}{l}\text { H5: Involuntary switching forces customers to } \\
\text { switch banks. }\end{array}$ & $\sqrt{ }$ & \\
\hline $\begin{array}{l}\text { H6: There is a negative relationship between } \\
\text { favourable perception of distance and } \\
\text { customers' switching banks. }\end{array}$ & $\sqrt{ }$ & \\
\hline $\begin{array}{l}\text { H7: There is a negative relationship between } \\
\text { switching costs and customers' switching } \\
\text { banks. }\end{array}$ & $\sqrt{ }$ & \\
\hline
\end{tabular}


The coefficient value for Price, Reputation, Service Quality, Effective Advertising Competition, Involuntary Switching, Distance, and Switching Costs are significant at 0.05 level of significance. Involuntary Switching is significant at 0.10 level of significance. Thus, the factors Price, Reputation, Service Quality, Effective Advertising Competition, Involuntary Switching, Distance and Switching Costs, are all significant and likely to influence customers to switch banks. Table 5.12 shows that the Price factor positively influences customer switching behaviour, thereby supporting Hypothesis 1. The positive relationship also exists for the Reputation factor. Thus, Hypotheses 2 is satisfied as well. Hypotheses 3, 4, 5, 6 and 7 proposed that negative relationships exist between customers' switching behaviour and impact factors: Service Quality, Effective Advertising Competition, Involuntary Switching, Distance, and Switching Costs, therefore, Hypotheses 3, 4, 5, 6 and 7 are supported (see Table 5.12 and 5.13).

\subsection{Research Pertaining to Research Objective Two \& Three}

Research Objective Two \& Three are to determine the most and least important factors that influence bank customers' switching behaviour. Marginal effect analysis was used to satisfy Research Objective Two \& Three. Liao (1994) explains that the marginal effect illustrates the marginal change in the dependent variable, given a unit change in a selected independent variable, holding all other variables constant. The seven influencing factors derived from the factor analysis and the logistic regression model are ranked as follows: 
Table 5.14 Marginal Effects of Customers' Switching Behaviour

\begin{tabular}{|l|l|l|}
\hline Factors & Marginal Effect & Ranking \\
\hline Switching Costs & -0.15124442 & 1 \\
\hline Price & 0.12636227 & 2 \\
\hline Service Quality & -0.06767892 & 3 \\
\hline Distance & -0.06655337 & 4 \\
\hline Reputation & 0.05785655 & 5 \\
\hline Effective Advertising Competition & -0.04335349 & 6 \\
\hline Involuntary Switching & -0.04044224 & 7 \\
\hline
\end{tabular}

The marginal effects table shows that Switching Costs has the maximum impact on customers' bank switching behaviour. For example, the results show that a unit decrease in Switching Costs results in a $15.1 \%$ probability that a customer will switch banks. Price has the second highest impact on customers' bank switching behaviour. A unit increase in the Price factor (eg. bank fees) results in a $12.6 \%$ probability of customers' switching banks. The third most important factor influencing customers to switch banks is Service Quality. The marginal changes in the probability for Service Quality indicates that a unit decrease in the Service Quality score results in a $6.8 \%$ probability that customers will switch banks. Similarly, Distance, Reputation, Effective Advertising Competition and Involuntary Switching are the fourth, fifth, sixth and seventh important factors that impact customers' bank switching behaviour (see Table 5.14).

Table 5.15 shows the marginal effect of the groups based on their different demographic characteristics. 
Table 5.15: Marginal Effects of Customers’ Demographic Characteristics

\begin{tabular}{|l|l|l|}
\hline Factors & Marginal Effect & Ranking \\
\hline High Income Group & 0.65658411 & 1 \\
\hline Middle High Income Group & 0.58071518 & 2 \\
\hline Young Age Group & 0.39901222 & 3 \\
\hline Middle Income Group & 0.29095190 & 4 \\
\hline White Collar Group & 0.26491383 & 5 \\
\hline Other Occupations Group & 0.22047944 & 6 \\
\hline
\end{tabular}

The results in Table 5.15 show that respondents with high incomes is the most likely demographic group to switch banks as the probability of switching banks increases by 65.7\% for the High Income Group (CNY 6,000 and above). The Middle High Income Group (CNY 3,000 - 5,999) is the second most likely group to switch banks with a probability of $58 \%$. The results also indicate that the probability for customers to switch banks in the Young Age Group (18 to 25 years) is $40.0 \%$. Based on the marginal effect results, the fourth and the fifth most likely groups to switch banks are the Middle Income Group (CNY 500 - 2,999) and the White Collar Group. The sixth most likely to switch bank group is the respondents in the Other Occupations Group (eg. Householder, Retired, and Unemployed).

\subsection{Results Pertaining to Research Objective Four (Hypotheses 8}

\section{through 15)}

Research Objective Four examines the impact of the demographic characteristics on bank switching behaviour. Logistic regression analysis was used to test Hypotheses 8 to 14 to answer Research Objective Four. The summary test results for Hypotheses 8 to 14 are shown in Table 5.16 below based on the logistic regression results shown in Table 5.12 in Section 5.5. 
Table 5.16: Hypotheses 8 through 14 Test Results

\begin{tabular}{|l|c|c|}
\hline \multicolumn{1}{|c|}{ Hypotheses } & Supported & $\begin{array}{c}\text { Non } \\
\text { Supported }\end{array}$ \\
\hline $\begin{array}{l}\text { H8: There is a positive relationship between younger } \\
\text { age and customers' switching banks. }\end{array}$ & $\sqrt{ }$ & $\sqrt{ }$ \\
\hline $\begin{array}{l}\text { H9: There is a negative relationship between old age } \\
\text { and customers' switching banks. }\end{array}$ & $\sqrt{ }$ & $\sqrt{ }$ \\
\hline $\begin{array}{l}\text { H10: There is a positive relationship between high } \\
\text { income and customers' switching banks. }\end{array}$ & & $\sqrt{ }$ \\
\hline $\begin{array}{l}\text { H11: There is a negative relationship between low } \\
\text { income and customers' switching banks. }\end{array}$ & & $\sqrt{ }$ \\
\hline $\begin{array}{l}\text { H12: There is a positive relationship between higher } \\
\text { education levels and customers' switching bank. }\end{array}$ & & \\
\hline $\begin{array}{l}\text { H13: There is a negative relationship between lower } \\
\text { education levels and customers' switching banks. }\end{array}$ & $\sqrt{ }$ \\
\hline $\begin{array}{l}\text { H14: There is a positive relationship between white- } \\
\text { collar and customers' switching banks. }\end{array}$ & & \\
\hline
\end{tabular}

The results show that the coefficient values for the Young Age Group are significant at 0.05 level of significance. Therefore, Hypothesis 8 is supported. Significant relationships also exist between the Middle Income Group (CNY 500-2,999), Middle High Income Group (CNY 3,000-5,999), the High Income Group (CNY 6,000 and above) and bank switching behaviour. Consequently, Hypothesis 10 is supported. Hypothesis 14 is also supported as there is significant relationship between the White Collar Group and bank switching. However, the coefficient values for the Old-age Group, Low Income, Low Education and High Education are not significant at 0.05 level of significance. Thus, Hypothesis 9, 11, 12 and 13 are rejected.

In order to minimise the effects of small sample size, Householders, Retired, Unemployed and Other Jobs have been categorised into one group, namely the Other Occupations. The results also show that the Other Occupations Group is significant at 0.05 level of significance. 
Based on the results, the Young Age Group has a positive and significant effect on switching banks, and this indicates that young customer are most likely to switch banks. In addition, the respondents who work as a professional, or are self-employed, normally have high incomes and are more likely to switch banks.

In addition, ANOVA and T-test were employed to test Hypotheses 15 to examine whether there are any different perceptions of the switching factors between demographic groups. The categorical variables in the questionnaire (see Appendix 2) were combined into the groups for the logit analysis, ANOVA and Scheff Test. The results in Table 5.17 show that Males and Females have a different perception of Distance, an important switching factor. Customers with different ages, educational levels, and incomes, have different perceptions of the influencing factors: Service Quality, Reputation, Switching Costs, and Involuntary Switching (see Table 5.18, 5.19 and 5.20).

In terms of age, the results (see Table 5.21) indicate that a banks' reputation is more important for the Young and Middle Age Groups than Middle-Old and Old Age Groups. However, the Old Age Group is more concerned with Service Quality compared to the Middle Age Group.

Service Quality is seen as a more important factor by the High Education Group than the other groups with Low, Middle and Middle-High Education levels (see Table 5.22). 
The results in Table 5.23 illustrates that Switching Costs is more important for the respondents in the High Income Group (monthly income CNY6,000 and above) than for those respondents in the Low Income Group (monthly income below CNY6,000).

\subsection{Chapter Summary}

This chapter presented the results based on the research plan and methodology discussed in Chapter Four. A preliminary examination of the data set indicates that the questionnaire is reliable and valid, and the statistical assumptions required to perform factor analysis and logistic regression have been met. Seven factors were extracted and 15 hypotheses were tested using logistic regression. The marginal effects met the requirement of ranking the factors that influence bank switching from the most to least important. Finally, ANOVA and T-tests indicated that customers with different demographic characteristics exhibit different to bank switching behaviour. 


\section{Chapter 6 Conclusions and Implications}

\subsection{Introduction}

This chapter summarises the research findings presented in Chapter Five and their theoretical and managerial implications. The research limitations and directions for future research are also discussed.

The four Research Objectives in this study were addressed by testing 15 hypotheses. Hypotheses 1 through 7 relate to Objective One. Hypotheses 8 through 15 relate to Research Objective Four. Research Objectives Two and Three were satisfied by examining the most and least important factors influencing customers' switching behaviour.

\subsection{Conclusions Pertaining to Research Objective One}

Research Objective One: To identify the factors that influence customers' switching behaviour in the Chinese retail banking industry.

Research Objective One was satisfied as the factors that influence customers' switching behaviour in the Chinese retail banking industry were identified. The result of the logistic regression analysis showed that there was a significantly positive relationship between customers' switching behaviour and the influencing factors: Price and Reputation. Therefore, Hypotheses 1 and 2 were supported. This result 
supports the findings of Gerrard \& Cunningham (2004), Colgate \& Hedge (2001), Almossawi (2001), and Keaveney (1985), as these authors regard price and reputation as important factors that influence customers' to switch banks.

The results showed that there was a significantly negative relationship between customers' switching behaviour and the influencing factors: Service Quality, Effective Advertising Competition, Involuntary Switching, Distance and Switching Costs. Consequently, Hypotheses 3, 4, 5, 6, and 7 were supported. These findings are consistent with those of Clemes et al. (2007), Matthews \& Murray (2007), Ganesh et al. (2000), and Levesque \& McDougall (1996) that these factors significantly affected customers' switching behaviour.

\subsection{Conclusions Pertaining to Research Objective Two and Three}

Research Objective Two: To determine the most important factors that influence customers' switching behaviour in the Chinese retail banking industry.

Research Objective Three: To determine the least important factors that influence customers' switching behaviour in the Chinese retail banking industry.

These two objectives were satisfied as the most and least important factors were determined. The marginal-effect results showed that Switching Costs had the maximum impact on switching behaviour. Price and Service Quality were the second and third important factors influencing customers' switching behaviour. The fourth and fifth most important factors were Distance and Reputation respectively. Effective 
Advertising Competition and Involuntary Switching were ranked as the sixth and seventh most important factors according to the marginal-effect result (see Table 5.14 in Chapter Five).

With regards to the demographic characteristics, the customers with High Incomes had the highest probability to switch banks, followed by the Middle-High Income Group. The third most important demographic characteristic impacting customers' switching behaviour was the group aged between 18 to 25 years. The Middle Income Group and White Collar Group were the fourth and fifth most likely groups to switch banks, followed by the respondents in the Other Occupations Group (eg. Householders, Retired, Unemployed and Other Jobs).

\subsection{Conclusions Pertaining to Research Objective Four}

Research Objective Four: To determine the impact of the demographic characteristics on customers' switching behaviour in the Chinese retail banking industry.

This objective was satisfied. However, only Age, Income and Occupation had an impact on customers' switching behaviour. The logistic regression results revealed that the Young Age, High Incomes, and White Collar Groups were positively associated with bank switching behaviour. Therefore, Hypotheses 8, 10 and 14 were supported. The ANOVA and T-test results showed that customers with different gender, age, educational levels and incomes, had different perceptions of the switching factors: Reputation, Service Quality, Distance, Switching Costs, and Involuntary Switching. Thus, Hypotheses 15 was supported. These results are 
consistent with Colgate \& Hedge's (2001) finding that bank switching is common among younger, high-income, and higher educated customers than older, low-income, and less-educated customers. Although there is limited empirical research regarding the white collar group and switching behaviour, there is a positive relationship between white collar occupations and high incomes in China that supports the findings of this study (Li, 2008; China Daily, 2007).

However, there were no clear relationships between the Old Age \& Low Income Groups and customers' switching behaviour. Thus, Hypotheses 9 and 11 were rejected. Hypotheses 12 and 13 were also rejected as education did not significantly impact on bank switching behaviour. These results are consistent with some of the research findings, such as Mavri \& Ioannou (2008), Garland (2002). These researchers show no statistically significant difference between any of the groups in terms of educational status and bank switching behaviour.

\subsection{Theoretical Implications}

This research makes a number of contributions to customers' switching behaviour in the banking industry. Firstly, this research contributes to the limited empirical studies currently available on consumers' retail bank switching behaviour, especially in the Chinese banking context. This study provides useful knowledge about consumers' switching behaviour in the Chinese retail banking industry by empirically identifying the factors that influence customers to switch banks. 
Secondly, a logistic regression analysis is used as the methodology to examine customers' switching behaviour in this research. The results of this research support logistic regression analysis as an appropriate methodology that can be applied in examining customers' bank switching behaviour.

Thirdly, this research confirms that some of the factors influencing customers' switching behaviour identified in previous research can also be applied to Chinese banking, such as Price, Reputation, Service Quality, Effective Advertising Competition, Involuntary Switching, and Switching Costs. Furthermore, this research also identifies a factor that may be particularly important to the Chinese banking sector - Distance. This factor may also be appropriate as a factor to consider for other international studies on customer bank switching behaviour.

\subsection{Managerial Implication}

\section{Switching Costs}

This research reveals that switching costs have the strongest influence on customers' decision to switch banks, especially for high income customers. This result is consistent with a number of researchers that regard switching costs as the main determinant of behavioural loyalty in customer markets (Caruana, 2004; Burnham, Frels \& Mahajan, 2003; Heide \& Weis, 1995). From a customers' viewpoint, the termination costs from a previous service provider, and the joining costs with an alternative service provider are often unavoidable. From a managers' viewpoint, switching costs can occur from losing interpersonal or long-term relationships with their customers (Burnham et al., 2003; Patterson \& Smith, 2003). 
Thus, in order to reduce customers' switching banks, bank managers should try to increase the switching barriers to make the switching process more complicated. Berry \& Parasuraman (1991) find that switching costs can be raised once customers increase their dependency on the long-term relationship, this may be particularly more important for the high income customers with various investments. Banks can also link customers' portfolio investments or bond entities with their bank account directly. If a customer intends to switch to another bank, he/she has to notify all his/her portfolio investment entities one by one, a time consuming process. In addition, banks can enhance customer relationships through providing extra benefits to loyal customers, such as offering $10 \%$ off to the customers who buy home insurance from current banks over a three year period. These methods encourage customers to use a wide range of banking services, and consequently it takes time for customers to make alternative banking arrangements.

\section{Price}

The results of this study confirm that price is another important factor influencing customers to switch banks (Gerrard \& Cunningham, 2004; Zeithaml, 1998; Keaveny, 1995). Due to the complicated nature of the banking industry, price includes not only fees implementation, and bank charges, but also the interest rates charged and paid (Gerrard \& Cunningham, 2004). As a result of banking complexities, banks find it challenging to develop pricing strategies that are markedly different from their major competitors. Occasionally, banks may offer low borrowing rates or high deposit rates to attract customers and reduce defection. However, focusing only on the price variable may not be an optimum strategy. Simply offering high deposit rate, imposing 
minimum charges on customers, and increasing fee rates at the same time, is not an effective way to reduce customer defection rates (Gerrard \& Cunningham, 2004). These pricing changes may result in negative effects, such as encouraging customers to switch to another bank that provides better price options (Gerrard \& Cunningham, 2004).

Reducing a bank's own costs is one strategy that may reduce the number of customers who switch. For example, electronic banking plays an important role in reducing services costs. Customers using electronic banking can experience lower fixed and variable costs that are associated with banking operations, due to reductions in human errors and savings in labour costs (Gan et al., 2006). Similarly, Polatuglu \& Ekin (2001) identify that cost savings through electronic banking makes a significant contribution to reducing costs.

Price has the second strongest influence on customers' switching behaviour, and any changes in interest rates and/or fees should be considered carefully by bank management before the changes are involved.

\section{Service Quality}

This study also reveals that service quality is an important factor influencing customers' bank switching behaviour. Several researchers indicate that service quality plays an important role in supporting business development as service quality has favorable impact on customer satisfaction, repurchase behaviour and business profitability (Zeithaml et al., 1996; Julian \& Ramaseshan, 1994). Bank management needs to focus more on achieving high service quality as a competitive differentiation 
method. Service attributes, such as ease of access, provision of information and innovative products, can enhance customer loyalty (Moutinho \& Smith, 2000; Nguyen \& LeBlanc, 1998). In addition, the results show that service quality is a more important switching factor among Old Age and High Education Groups. This finding suggests that the more experiences and the better knowledge people have, the greater their expectation of service quality (Zeithaml et al., 1996). Therefore, focusing on the needs of customer segments is necessary, such as providing resting areas and consulting services to older people, or offering personalised investment-consulting services to knowledgeable customers.

Basically, service quality should focus not only on the service offered, but also on the people who deliver the service (Gerrard \& Cunningham, 2004). The service characteristics of the banking industry make inter-actions between customers and employees necessary. Banks' staff should have good banking knowledge, act professionally, and have a courteous attitude towards all customers. An appropriate people management strategy is necessary in order for bank staff to deliver high quality services.

\section{Reputation}

Another valuable finding from this study is the importance of reputation as a switching antecedent. A good reputation plays an important role in creating positive signals to the public about the firms' capability and reliability (Vendelo, 1998). Thus, bank managers have to find ways to encourage the development of trust between customers and banks that eventually leads to loyalty. Other than providing timely and accurate services, managers need to encourage their employees to communicate with 
customers in a manner that inspires trust and confidence. Furthermore, the result shows that reputation is more critical for the Young and Middle Age Groups than the Middle Old, and Old Age Groups. Therefore, banks may enhance their reputation using communication approach that is more acceptable for the younger people, such as providing financial up-dates through the Internet.

\section{Effective Advertising Competition}

Based on the empirical finding of this study, advertising plays a significant role in determining customers' switching behaviour. Bank managers should develop strategies that enhance the communication channels between customers and banks. Once customers understand the offerings and processes of their current bank, the probability of switching to an alternative bank is considerably reduced (Clemes et al., 2007). With the emergence of high technology (the Internet), Television and radio are not the only ways to communicate information and advertise a bank's offerings. The Internet enables all customers to be informed globally in matter of seconds. However, billboards may still be an effective way for the older people. Therefore, multiple advertising methods are required to target different demographic characteristic groups. Whereas, all advertising information should be carefully filtered prior to be dispensed since it may create opportunities for competitors to use to attract customers.

\section{Distance}

The findings show that distance is another antecedent that affects customers' switching behaviour, and distance is perceived differently by Females and Males. Distance may play an important role in influencing customers that are concerned more convenience as it allows them to save time. This result also suggests that customers 
(eg. housewife) may tend to choose the nearest bank, especially if there is a limited geographical accessibility to alternative banks (Kiser, 2002). Although internet banking reduces the distance between customers and banks, the technology does not help those customers who prefer face-to-face communication, especially for older people who may be reluctant to use the Internet. This result may encourage bank management to carefully consider closing bank branches that may not be profitable, but are conveniently assessable by customer segments.

\section{Involuntary Switching}

The results confirm that customers' switching behaviour can also be affected by involuntary switching factors, such as moving house, changing jobs, and the opening or closing of a bank branch. Under these circumstances, bank managers may use electronic banking services such as Automatic Teller Machine (ATM), telephone and internet banking, to lower defection rates (Dutta \& Segev, 2001). Electronic banking can efficiently and effectively improve the traditional marketing functions of a financial institution, especially when there is time or geographical location constraints (Gan et al., 2006).

\section{Demographic Characteristic}

The finding reveals that the Young Age Group is the age group that is most likely to switch banks. The results are consistent with many researches (Oliver, 2004; Colgate \& Hedge, 2001). Younger customers switch banks due to greater convenience, higher quality services, lower prices, or more favorable interest rates. 
According to Tripe $(2004)^{3}$, bank switching behaviour is much more common among the young generation as they do not have too many links with their banks. Therefore, bank managers should try to establish a durable relationship with their young customers in order to build up a long-term relationship over time. For example, bank managements can link their online services with a cell phone company to enable cell phone banking which is readily adopted by young age customers (Oliver, 2004).

This research also illustrates that respondents with High Incomes tend to switch banks. This may be because these customers tend to have greater expectations of bank services. In general, high income customers expect better services from their banks since they normally have greater purchasing power. Furthermore, the majority of the banks' profit is derived from high income customers. Therefore, in order to protect bank profits, other than by providing superior services, offering special benefits may be necessary to retain customers in this customer segments. For example, the Auckland Saving Bank in New Zealand allows customers to negotiate the term deposit rates for amounts over $\mathrm{NZ} \$ 250,000$.

\subsection{Limitations and Avenues for Future Research}

Although this study provides contributions from both a theoretical and practical perspective, there are a few limitations.

First, this research was conducted in Henan Province of China. People's belief and attitudes can be significantly different across different regions and countries.

\footnotetext{
${ }^{3}$ David Tripe is a banking analyst of Massey University, quoted from the New Zealand Herald (2004). Banking on Young Love.
} 
Furthermore, the sample respondents were limited to customers in the mall who were willing to be surveyed, and the non-probability sample does not allow assessment of sampling error. Therefore, a more extended geographic sample may reveal differences in customers' attitudes towards bank switching behaviour, which would also have managerial implications.

Secondly, this study empirically examined seven factors that may influence customers' switching bank behaviour. However, there maybe some other factors that can have an impact on customers' switching behaviour but were not examined in this study. Further empirical research is required to examine the other factors that can impact or influence customers' switching decisions.

Third, this research focuses on customers' past behavioural intentions rather than their future behavioural intentions. The survey questions ask about respondents' banking experiences with their current banks or their new banks. However, in order to maintain a long-term relationship with customers, future research should focus not only on what factors influence customers to switch banks, but also on any additional factors that can potentially influence customers to switch banks in the future.

\subsection{Conclusion}

This research illustrates a range of factors that influence Chinese bank customers' switching behaviour through an exploratory investigation. This study also shows that some factors are more influential than others. An understanding of these influencing factors allows managers to direct efforts and resources in the most effective and 
efficient way to prevent customers' departure, and reduce business losses in the long run that result from customers switching banks.

Switching costs are identified as the most important factor that influences the customers to switch banks. However, banks should not only rely on increasing switching costs in an attempt to retain their customer base because doing so could bring downside effects to banks, such as negative word-of-mouth from disgruntled customers (Gerrard \& Cunningham, 2004). Positive efforts are necessary.

Banks who try to attract new customers from their competitors will also benefit from an understanding of what factors cause customers to switch banks. Bank managers can make use of such information to develop appropriate strategies to attract new customers.

In general, the greater the knowledge the bank management has about the factors affecting their customers switching behaviour, the greater their ability to develop appropriate strategies to reduce bank switching. 


\section{REFERENCES}

Aaker, D. A. (1996). Managing Brand Equity. New York: The Free Press.

Aaker, D. A., Kumar, V., Day, G. S., \& Lawley, M. (2005). Marketing research: The pacific rim edition. Queensland, Australia: John Wiley \& Sons Australia.

Aldlaigan, A. H., \& Buttle, F. A. (2002). SYSTRA-SQ: A new measure of bank service quality. International Journal of Service Industry Management, 4, 362381.

Alexandris, K., Dimitriadis, N., \& Markata, D. (2002). Can perceptions of service quality predict behaviour intentions? An exploratory study in the hotel sector in Greece. Managing Service Quality, 12(4), 224-232.

Almossawi, M. (2001). Bank selection criteria employed by college students in Bahrain: an empirical analysis. International Journal of Bank Marketing. 19(3), 115-125.

Amemiya, T. (1981). Qualitative response model: A survey. Journal of Economic Literature, 19, 1485-1536.

Anderson, E., \& Sullivan, M.W. (1993). The antecedents and consequences of customer satisfaction for firms. Marketing Science, 12(2), 125-43.

Anderson, E., Fornell, C., \& Lehmann, D. R. (1994). Customer satisfaction, market share, and profitability: Finding from Sweden. Journal of Marketing, 58(July), 53-66.

Andreasen, A.R. (1988). Consumer complaints and redress: What we know and what we don't know. American council of consumer interests. The United States: Columbia. MO.

Andreassen, T.W., \& Lindestad, B. (1998). The effect of corporate image in the formation of customer loyalty. Journal of Service Research, 1(1), 82-92.

Au, K., Hui, M. K., \& Leung, K. (2001). Who should be responsible ? Effects of voice and compensation on responsibility attribution, perceived justice, and post complaint behaviour across cultures. The International Journal of Conflict Management, 2(4), 350-364.

Avkiran, N. K., (1994). Developing an instrument to measure customer service quality in branch banking. The International Journal of Bank Marketing, 12(6), 10-19.

Bahia, K., \& Nantel, J. (2000). A reliable and valid measurement scale for the perceived servcie quality of banks. International Journal of Bank Marketing, 18(2), 84-91. 
Balmer, J. M. T., \& Stotving, S. (1997). Corporate identity and private banking: A review and case study. International Journal of Bank Marketing, 15(5), 169184.

Barchard, D. (1990). Where only interesting customers need apply. Financial Times, 9 October.

Barich, H., \& Kotler, P. (1991). A framework for marketing image management. Solan Management Review, Winter, 94-104.

Barney, J.B. (1991). Firm resources and sustained competitive advantage. Journal of Management, 17(1), 99-120.

Barr, G. (2009). Study: Reputation, products key for banks. Houston Business Journal Monday, May 11. Retrived August 1, 2009, from http://www.bizjournals.com/houston/stories/2009/05/11/daily7.html

Beckett, A., Hewer, P., \& Howcroft, B. (2000). An exposition of consumer behaviour in the financial services industry. The International Journal of Bank Marketing, 18 (1), 15-26.

Berggren, E., \& Dewar, R. (1991). Is product management obsolete? Journal of Retail Banking, 13 (4), 27-32.

Bejou, D., \& Palmer, A. (1998). Service failure and loyalty: an exploratory empirical study of airline customers. Journal of Services Marketing, 12(1), 7-22.

Ben-Akiva, M., \& Lerman, S. R. (1995). Discrete choice analysis-theory and application to travel demand. MIT press, Cambridge, Masachusetts, London.

Bendapudi, N., \& Berry, L.L. (1997). Customers' motivations for maintaining relationships with service providers. Journal of Retailing, 71 (3), 223-47.

Berry, L. L. (2000). Cultivating service brand equity. Journal of the Academy of Marketing Service, 28 (1), 128-37.

Berry, L.L., \& Parasuraman, A. (1991), Marketing service: Competing through quality, The Free Press, New York, NY.

Bitner, M. (1990). Evaluating Service Encounters: The effects of physical surroundings and employee responses. Journal of Marketing, 54(2), 69-82.

Bitner, M. J., Ostrom, A. L., \& Meuter, M. L. (2002). Implementing successful selfservice technologies. The Academy of Management Executive, 16(4), 96-109.

Bitner, M.J., \& Hubbert, A.R. (1994). Encounter satisfaction versus overall satisfaction versus quality. in Rust, R.T. and Oliver, R.L. (Eds), Service Quality: New Directions in Theory and Practice, Sage, London. 
Blanchard, R. F., \& Galloway, R. L. (1994). Quality in retail banking. International Journal of Services Industry Management, 5(4), 5-23.

Block, C. \& Roering, K. J. (1976). Essential of customer behaviour: Based on engel, kollat, and blackwell's consumer behaviour. The Dryden Press.

Bloemer, J., Ko, de. Ruyter., \& Peeters, P. (1998). Investigating drivers of bank loyalty: the complex relationship between image, service quality and satisfaction. International Journal of Bank Marketing, 16(7), 276-86.

Bolton, R. N., \& Bronkhurst, T. M. (1995). The relationship between customer complaints to the firm and subsequent exist behaviour. Advances in Consumer Research, 22, 92-100

Boote, J. (1998). Towards a comprehensive taxonomy and model of consumer complaining behaviour. Journal of Consume Satisfaction, Dissatisfaction and Complaining Behaviour, 11, 141-149

Brady, M. K., \& Cronin, J. J. (2001). Some new thoughts on conceptualizing perceived service quality: A hierarchical approach. Journal of Marketing, 65(3), 34-49.

Bryman, A., \& Cramer, D. (1999). Quantitative Data Analysis with SPSS Release 8 for Windows: A guide for social scientists. London: Routledge.

Burnham, T.A., Frels, J.K., \& Mahajan, V. (2003). Consumer switching costs: a typology, antecedents, and consequences. Journal of the Academy of the Academy of Marketing Science, 31(2), 109-26.

Campbell, M. C. (1999). Perceptions of price unfairness: Antecedents and consequences. Journal of Marketing Research, 36(2), 187-200.

Caruana, A. (2004). The impact of switching costs on customer loyalty: a study among corporate customers of mobile telephony. Journal of Targeting, Measurement and Analysis for Marketing, 12(3), 256-68.

Cengiz, E., Ayyildiz, H., \& Er. B. (2007). Effects of image and adverting efficiency on customer loyalty and antecedents of loyalty: Turkish banks sample. Banks and Bank Systems, 2(1), 56-80.

Chakravarty, S., Feinberg, R., \& Rhee, E. (2004). Relationships and Individuals' bank switching behaviour. Journal of Economic Psychology, 25, 501-27.

Chen, I. J., Gupta, A., \& Rom, W. (1994). A study of price and quality in service operations. International Journal of Service Industry Management, 5(2), 23-34.

Churchill, G. A. (1979). A paradigm for developing better measures of marketing constructs. Journal of Marketing Research, 16(1), 64-73. 
Clemes, M. D., Gan, C., \& Kao, T. H. (2007). University satisfaction: An empirical analysis. Journal of Marketing for High Education, 17(2), 292-325.

Clemes, M. D., Gan, C., \& Zheng, L, Y. (2007). Customer switching behaviour in the New Zealand banking industry. Banks and Banks System, 2(4), 50-66.

Coakes, S. J., Steed, L. G. \& Price, J. (2008). SPSS version 15.0 for window: Analysis without anguish. Milton, Queensland: John Wiley \& Sons Australia.

Cohen, J., Cohen, P., West, S. G., \& Aiken, L. S. (2003). Applied multiple regression/correlation analysis for the behavioral sciences (3rd ed.). New Jersey: Lawrence Erlbaum Associates.

Colgate, M. (1999). Customer satisfaction and loyalty: How New Zealand banks need to improve. University of Auckland Business Review, 1(1), 36-48.

Colgate, M., \& Hedge, R. (2001). An investigation into the switching process in retail banking services. The International Journal of Bank Marketing, 19(4/5), 201213.

Colgate, M., \& Lang, B. (2001). Switching barriers in consumer markets: An investigation of the financial services industry. The Journal of Consumer Marketing, 18(4/5), 332-348.

Colgate, M., Steward, K., \& Kinsella, R. (1996). Customer Defection: A study of student market in Ireland. International Journal of Bank Marketing, 14(3), 239.

Cooper, D. R., \& Schindler, P. S. (2006). Business research methods (9th ed). New York, NY: McGraw-Hill/Irwin.

Crouch, S. (1984), Marketing research for managers, Butterworth-Heinemann, London, UK.

Dabholkar, P. A., Thorpe, D. I., \& Rentz, J. O. (1996). A measure of service quality for retail stores: Scale development and validation. Academy of Marketing Science Journal, 24(1), 3-16.

Dagger, T. S., Sweeney, J. C., \& Johnson, L. W. (2007). A hierarchical model of health service quality. Journal of Service Research, 10(12), 123-142.

Davies, M. (1996). Image problems with financial services: Some consideration for improvement. Management Decisions, 34 (2), 64-71.

Dawes, J. (2004). Price changes and defection level in a subscription - type market: Can an estimation model really predict defection level? The Journal of Service Marketing, 18(1), 35-44. 
Diane, H. (2003). Negative word of mouth: Substitute for or supplement to customer complaint? Journal of Consumer Satisfaction, Dissatisfaction and Complaining, 15(1), 1-12.

Dick, A.S., \& Basu, K. (1994). Customer loyalty: Toward an integrated conceptual framework. Journal of the Academy of Marketing Science, 22 (2), 99-113.

Dielman, T. E. (2001). Applied regression analysis for business and economics (3rd ed.). Duxbury: Thomson Learning.

Dixon, M. (1999). Com Madness: 9 Must-Know Tips for Putting Your Bank Online. Community Banks, 8(6), 12-15.

Dobson, W., \& Kashyap, A. (2006). The contradiction in China's gradualist banking reforms. Brookings Papers on Economic Activity, 2, 103-163.

Dowling, G., \& Staelin, R. (1994). A model of perceived risk and intended riskhandling activity. Journal of Consumer Research, 21(1), 119-134.

Duncan, E., \& Elliot, G. (2002). Customer service quality and financial performance among Australian retail financial institution. Journal of Financial Services Marketing, 7 (1), 25-41.

Dunn, D. (1995). Advertising and promotion. Retrieved August 1, 2009, from http://ag.arizona.edu/AREC/pubs/dmkt/Advertising\&Promo.pdf

Dusuki, A. W., \& Abdullah, N. I. (2006). Why do Malaysian customers patronise Islamic banks? The International Journal of Bank Marketing, 25(3), 142-160.

Duthie, L. (2005) Anthropology of work review. Retrieved August 1, 2009, from http://www.aaanet.org/sections/saw/awr/awr263.pdf

Dutta, S., \& Segev, A. (2001). Business transformation on the Internet. E-commerce and V-commerce: Business models for global success. Butterworth-Heinemann.

Easingwood, C., \& Storey, C. (1995). The impact of the new product management project on the success of financial services. Logistics information management, 8(4), 35-47.

Ehigie, B. O. (2006). Correlated of Customer Loyalty to Their Bank: A Case Study in Nigeria, International Journal of Bank Marketing, 24 (7), 494-508.

Engel, J. F., Blackwell, R. D., \& Miniard, P. W. (1995). Consumer behaviour (8th ed.) Fort Worth: The Dryden Press.

Ennew, C. T., \& Binks, M. R. (1996). The impact of service quality and service characteristics on customer retention: Small business and their banks in the UK. British Journal of Management, 7 (3), 219-230. 
Formbrun, C. I., \& Shanley, M. (1990). What's in a name? Reputation building and corporate strategy. Academy of Management Journal, 33(2), 233-258.

Fornell, C., \& Wernerfelt, B. (1987). Defensive marketing strategy by customer complaint management: A theoretical analysis. Journal of Marketing Research, 24, 337-346.

Fornell, C. (1992). A national customer satisfaction barometer: The Swedish experience. Journal of Marketing, 56, January, 6-21.

Fox, J. (1947). Applied regression analysis, linear models, and related methods.

Retrived August 1, 2009, from

http://books.google.com/books?id=TIC1gMlgXGsC\&pg=PA217\&lpg=PA217

$\& \mathrm{dq}=\mathrm{data},+$ polytomous,+ dummy+variable,+dichotomous\&source=bl\&ots=ZI

w46wrWN4\&sig=s_OCNwJMfWPXOjEPpxMnqI7Up4A\&hl=zh-

CN\&ei=i49NSqPwKoPmM_btqO0D\&sa=X\&oi=book_result\&ct=result\&resn um $=10$

Friedman, M., \& Smith, L. (1993). Consumer evaluation processes in a service setting. Journal of Services Marketing, 7 (2), 47-61.

Fry, J. N., Shaw, D. C., von Lanzenauer, C. H., \& Dipchand, C. R. (1973). Customer loyalty to banks: A longitudinal study. Journal of Business, 46, 517-525.

Furrer, O., Liu, S.C. \& Sudharshan, D. (2000). The relationship between culture and service quality perceptions: Basis for cross-cultural market segmentation and resource allocation. Journal of Service Research, 2(4), 355-371.

Gan, C., Clemes, M., \& Weng, A. (2006). A logit analysis of electronic banking in New Zealand. International Journal of Bank Marketing, 24(6), 360-383.

Ganesh, J., Arnold, M.J., \& Reynolds, K.E. (2000). Understanding the customer base of service providers: an examination of the differences between switchers and stayers. Journal of Marketing, 64(3), 65-87.

Gardial S., Flint, D., \& Woodruffe, R. (1996). Trigger events: exploring the relationships between critical events and consumer's evaluations, standards, emotions, values and behaviour. Journal of Consumer Satisfaction, Dissatisfaction and Complaint Behaviour, 9, 35-49.

Garland, R. (2002). Estimating customer defection in personal retail banking. The International Journal of Bank Marketing, 20 (7), 317-325.

Garland, R. (2002). Non-financial drivers of customer profitability in personal retail banking. Journal of Targeting, Measurement and Analysis in Marketing,10(3), 233-249.

Garson, G. D. (2006). Topics in multivariate analysis from Statnotes. Retrived July 1, 2008 from: http://www2.chass.ncsu.edu/garson/pa765/statnote.htm 
Garson, G. D. (2008a, September 27). Factor analysis from Statnotes: Topics in multivariate analysis. Retrived July 1, 2008 from

http://faculty.chass.ncsu.edu/garson/pa756/logistic.htm

Garson, G. D. (2008b, May21). Logistic Regression from Statnotes: Topics in multivariate analysis. Retrived from July 1, 2008 from http://faculty.chass.ncsu.edu/garson/pa765/logistic.htm

Gerrard, P., \& Cunningham, J. B. (2004). Consumer switching behaviour in the Asia banking market. The Journal of Service Marketing, 18(2/3), 215.

Gerrard, P., \& Cunningham, J.B (2000). The Bank switching behaviour of Singapore's graduates. Journal of Financial Services Marketing, 5(2), 118-28.

Gierl, H. (1993). Satisfied customer as brand switchers. Absatzwirtschaft, 37 (2), 9094.

Gonzalez, M. V. R., \& Guerrero, M. M. (2004). New competitors in banking service. Journal of Financial Services Marketing, 9(2), 126-138.

Greenbaum, T. L. (1998). The Handbook for Focus Group Research (2nd Edition). London: Sage.

Greene, W. H (2003). Economic Analysis. Upper Saddle River, NJ: Prentice Hall

Gronhaug, K., \& Gilly, M. C. (1991). A transaction cost approach to customer dissatisfaction and complaint actions. Journal of Economic Psychology, 12, 165-183.

Gronroos, C. (1984a). A service quality model and its marketing implication. European Journal of Marketing, 18(4), 35-44.

Gronroos, C. (1984b), Strategic management and marketing in the service sector. Studentlitteratur, Chartwell-Bratt.

Gronroos, C. (1988). Service quality: the six criteria of good perceived service. Review of Business, 19(3), 10-13.

Gronroos, C. (1990). Relationship approach to marketing in service context: The marketing and organizational behaviour interface. Journal of Business Research, 20, 3-11.

Grosby, L. A., \& Stephens, N. (1987). Effects of relationship marketing on satisfaction, retention, and Prices in the Life Insurance Industry. Journal of Marketing Research, 24, 404-411.

Hair, J. F. J., Bush, R. P., \& Ortinau, D. J. (2000). Marketing Research: A Practical Approach for the New Millennium. Singapore: McGraw-Hill. 
Hair, J. F., Black, W. C., Babin, B. J., Anderson, R. E., \& Thatham, R. L. (2006). Multivariate data analysis (6th ed.). Upper Saddle River, NJ: Prentice Hall.

Hall, R. (1993). A framework linking intangible resources and capabilities to sustainable advantage. Strategic Management Journal, 14(8), 607-618.

Hauser, J.R., Simester, D.I., \& Wernerfelt, B. (1994). Customer satisfaction incentives. Marketing Science, 13(4), Fall, 327-350.

Heide, J.B., \& Weiss, A.M. (1995). Vendor consideration and switching behaviour for buyers in high-technology markets. Journal of Marketing, 59(3), 30-43.

Hirschman, A. O. (1970). Exit, voice and loyalty. Harvard University Press, Cambridge, MA.

Hite, R. E., \& Fraser, C. (1998). Meta-analyses of attitudes towards advertising by professionals. Journal of Marketing, 52, July, 95-105.

Hocutt, M. (1998). Relationship dissolution model: Antecedents of relationship commitment and the likelihood of dissolving a relationship. International Journal of Service Industry Management, 9(2), 189-200.

James, P. T. F. (1998). The effect of nonverbal cues on bank patrons. Management Research News, 21(10), 14-33.

Javalgi, R. G., Armaco, R. L., \& Hoseini, J. C. (1989). Using the analytical hierarchy process for bank management: Analysis of consumer selection decisions. Journal of Business Research, 19, 33-49.

Jones, A.M., Mothersbaugh, L.D., \& Beautty, E.S. (2002). Why customers stay: measuring the underlying dimensions of services switching costs and managing their differential strategic outcomes. Journal of Business Research, $55,441-50$.

Jones, T. O., \& Sasser, W. E. Jr. (1995). Why satisfied customers defect. Harvard Business Review, 73, 88-99.

Judge, G. G., Hill, R. C., Criffiths, W. E., Lutkepohl, H., \& Lee. T. (1982). Introduction to the theory and practice of econometrics. New York: Wilay.

Julian, C. C., \& Ramaseshan, B. (1994). The role of customer-contact personnel in the marketing of retail bank's service. International Journal of Retail \& Distribution, 22(5), 29-35.

Jun, M., \& Cai, S. (2001). The key determinants of internet banking service quality: a content analysis. International Journal of bank marketing, 19(7), 276-291.

Kaiser, H. R., \& Rice, J. (1974). Little jiffy mark IV. Educational and Psychological Measurment, 34(1), 111-117. 
Kamilia, B., \& Jacques, N. (2000). A reliable and valid measurement scale for the perceived service quality of banks. The International Journal of Bank Marketing, 18(2), 81-91.

Kaynak, E., \& Kucukemiroglu, O. (1992). Bank and product selection: Hong Kong. The International Journal of Bank Marketing, 10(1), 3-17.

Keaveney, S. M. (1995). Customer switching behaviour in service industries: An exploratory study. Journal of Marketing, 59 (2), 71-83.

Keaveny, S. \& Parthasarathy, M. (2001). Customer switching behaviour in online services: An exploratory study of the role of selected attitudinal behaviour, and demographic factors. Journal of Academy of Marketing Science, 29(4), 374390.

Kiser, E. K. (2002). Household switching behaviour at depository institutions: Evidence from survey DATA. Antitrust Bulletin, 47(4), 619-641.

Lannes, B., \& Stratton, O. (2006). How to win in retail banking in China. China Daily (North American ed.). New York, N.Y. Nov 24.

Lee, H., Lee, Y., \& Yoo, D. (2000). The determinants of perceived service quality and its relationship with satisfaction. The Journal of Service Marketing, 14(3), 271-231.

Lee, M., \& Cunningham, L. F. (2001). A cost/benefit approach to understanding service loyalty. The Journal of Services Marketing, 15(2), 113-130.

Leeds, B. (1992). Mastery shopping offers clues to quality service. Bank Marketing, 24(11), November, 24-27.

Lees, G., Garland, R., \& Wright, M. (2007). Switching banks: Old bank gone but not forgotten. Journal of Financial Services Marketing. London: Nov 2007, 12 (2), 146-157.

Lehtinen, U., \& Lehtinen, J. R. (1982). Service quality: A study of quality dimensions. working paper, Service Management Institution, Helsinki, Finland.

Lethtinen, U., \& Lehtinen, J. (1991). Two approaches to service quality dimensions. Service Industries Journal, 11(3), 278-303.

Leonard, F. S., \& Sasser, W. E. (1982). The Incline of quality. Harvard Business Review, 60 (September-October), 163-171.

Levesque, T.J., \& McDougall, G. (1996a). Customer dissatisfaction: The relationship between types of problems and customer response, Revue Canadienne des Sciences de 1 Administration. Canadian Journal of Administrative Sciences, 13(3), 264-276. 
Levesque, T.J., \& McDougall, G. (1996b). Determinants of customer satisfaction in retail banking. International Journal of Bank Marketing, 14(7), 12-20.

Lewis, B. R (1989). Quality in the service sector: A review. International Journal of Bank Marketing, 7(5), 4-12.

Lewis, R.C. \& Booms, B.H. (1983). The marketing aspects of service quality, in Berry, L.L., Shostack, G. and Upah, G. (Eds), Emerging Perspectives in Service Marketing, American Marketing Association, Chicago, IL, 99-107.

Lewis. R. R., \& Soureli. M. (2006). The antecedents of customer loyalty in retail banking. Journal of Consumer Behaviour, February 5, 15-31.

Li, C. L. (2008). Profile of middle class in mainland China. Retrived July 1, 2009 from http://www.sociology.cass.net.cn/pws/lichunling/grwj_lichunling/P020090525 597135469507.pdf

Liao, T. F. (1994). Interpreting probability models: Logit, probit, and other genelaized liner modesl. Sage Publication.

Maddala, G. S. (2001). Introduction to econometrics (3rd ed.). New York: Wiley.

Malhotra, N. K. (2004). Marketing research-an applied orientation. (4th ed.). Person Education. (International Edition).

Martins, M., \& Monroe, K. B. (1994). Perceived price fairness : A new look at an old construct, in Advances in Consumer Research, (21), Chris T. Allen and Deborah Roedder John, Eds. Provo, UT: Association for Consumer Research, 75-78.

Matthews, C., \& Murray, D. (2007) Helping bank customers switch: A case study. Journal of Financial Services Marketing, 11(4), 360-370.

Mavri.M., \& Ioannou. G. (2008). Customer switching behaviour in Greek banking services using survival analysis. Managerial Finance, 34(3), 186-197.

Mazumdar, T. (1993). A value-based orientation to new product planning. Journal of Consumer Marketing, 10(1), 28-41.

Miller, J. R., \& Hay, M. J. (1981). Determinants of hunter participation: Duck hunting in the Mississippi flyway southern. Journal of Agriculture Economics, 63(4), 677-684.

Mitta, B., \& Lasser, W. M. (1998). Why do customers switch? The dynamics of satisfaction versus Loyalty. The Journal of Services Marketing, 12(3), 177-194.

Mittal, V., \& Kamakura, W. A.(2001). Satisfaction, repurchase intent, and repurchase behavior: Investigating the moderating effect of customer characteristics. Journal of Marketing Research, 38 (1), 131-143. 
Morgan, J. (2007). Customer Information Management (CIM): The key to successful CRM in financial services. Journal of Performance Management, 20 (2), 4766.

Moutinho, L., \& Smith. A.(2000). Modeling bank customer satisfaction through mediation of attitudes towards human and automated banking. The International Journal of Bank Marketing, 18(3), 124-134.

Murray, K.B. (1991). A test of services marketing theory; consumer information acquisition activities. Journal of Marketing, 55, January, 10-25.

Nguyen, N., \& Leblanc, G. (2001). Corporate image and corporate reputation in customers' retention decisions in services. Journal of Retailing and Consumer Servcies, 8(4), 227-36.

Nguyen, N., \& Le Balnc, G. (1998). The mediating role of corporate image on customers' retention decisions: an investigation in financial services. International Journal of Bank Marketing, 16(2), 52-65.

O’Brien, L., \& Jones, C. (1995). Do rewards really create loyalty? Harvard Business Review, 73, 75-82.

Oliver, P. (2004). Banking on young love. The New Zealand Herald.

Parasuraman, A., Zeithaml, V., \& Berry, L. (1985). A conceptual model of service quality and its implications for future research. Journal of Marketing, 49, Fall, 41-50.

Parasuraman, A., Zeithaml, V. A. \& Berry, L. (1988). SERVQUAL: A multiple-item scale for measuring consumer perceptions of service quality. Journal of Retailing, 64, Spring, 12-40.

Parasuraman, A., Zeithaml, V. A. \& Berry, L. (1991). Refinement and reassessment of the SERVUQAL scale. Journal of Retailing, 67 (4), 420-450.

Parasuraman, A., Zeithaml, V.A. and Berry, L.L. (1994). Reassessment of expectations as a comparison standard in measuring service quality: implications for further research. Journal of Marketing, 58, January, 111-124.

Patterson, P. G., \& Smith, T. (2003). A cross-cultural study of switching barriers and propensity to stay with service providers. Journal of Retailing, 79, 107-120.

Peng, M.W., \& Health, PS. (1996). The growth of firm in planned economies in transition: Institutions, organizations, and strategic choice. Academy of Management Review, 21(2), 492-528.

Peppard, J. (2000). Customer relationship management (CRM) in financial services. European Management Journal, 18(3), 312-327. 
Pindyck. R. S., \& Rubinfeld, D. L. (1991). Econometric models and economic forecasts. (3rd ed.). New York: McGraw-Hill.

Polatoglu, V. N., \& Ekin, S. (2001). An empirical investigation of the Turkish customers' acceptance of internet banking services. International Journal of Bank Marketing. 19(4), 156-165.

Ramanathan, R.(1992). Introductory Econometrics with applications. (2nd ed.). London: Fort Worth.

Rao, H. (1994). The social construction of reputation: Certification contests legitimation, and the survival of organizations in the automobile industry: 1985-1912. Strategic Management Journal, 15, 29-44.

Ratchford, Brian T. (1999). The economics of consumer knowledge. working paper, Marketing Department, SUNY Buffalo.

Reichheld, F., \& Sasser, W.E. Jr. (1990). Zero defections: Quality comes to services. Harvard Business Review, 68, September/October, 105-111.

Reichheld, F. F. (1993). Loyalty-based management. Harvard Business Review, 6473.

Reichheld, F. F. (1996). The Loyalty Effect. Harvard Business School Press, Boston, MA.

Rongstad, N. (1999). Look Deep In your houseflies database for sings of Impending customer defection. Target Marketing, July, 28-29.

Roos, I., (1999). Switching processes in customer relationships. Journal of Service Research, 2(1), 376-393.

Rust, R. T., \& Oliver, R. L. (1994). Service quality: Insights and managerial implications from the frontier. In R. T. Rust, \& R. L. Oliver (Eds.), Service quality: New direction in theory and practice (pp.1-19). Thousand Oak: Sage Publications.

Rust, R., \& Zahorik, A. (1993). Customer satisfaction, customer retention, and market share. Journal of Retailing, 69(2), 193-215.

Rust, R.T., Zahorik, AJ., \& Keiningham, T.L. (1996), Services marketing, Harper Collins College Publishers, New York, NY.

Rust, R.T., Zeithaml, V.A., \& Lemon, K.N. (2001). Driving customer equity: How customer lifetime value. New York, Free Press.

Rusthon, A. M., \& Carson, D. J. (1989). The marketing of services: Managing the intangibles. European Journal of Marketing, 23(8), 230-244. 
Salary size set for white-collar jobs. (2007). China Daily, November 7. Retrieved August 1, 2009, from http://beijing2008.german.china.org.cn/english/China/230774.htm

Schall, M. (2003). Best practice in the assessment of hotel-guest attitude. Cornell Hotel and Restaurant Administration Quarterly, 44(2), 51-65.

Scharioth, J., \& Hurber, M. (2002). Achieving excellence in stakeholder management New York: Springer.

Sekaran, U. (2003). Research methods for business: A skill building approach (4th ed). New York, NY: John Wiley \& Sons.

Sellar, C., Chavas, J. P., \& Stoll, J. R. (1982). Specification of the logit model: The case of valuation of nonmarket goods. Natural resources working paper services, TA-18178. Natural resources workgroup. Department of Agricultural Economics, Texas A \& M University.

Shapiro, C. (1993). Premiums of high quality products as returns to reputation. Quarterly Journal of Economics, 98(4), 659-79.

Shedd, W. (1996). Turning back churn. Telecommmunications, 30(11). November, 7376.

Siles, M., Robinson, L. J., \& Hanson, S. D. (1994). Does friendly service retain customers? Bank Marketing, 26(1), January, 47-50.

Smith, A.M. \& Reynolds, N.L. (2001). Measuring cross cultural service quality: A framework for assessment. International Marketing Review, Vol. 19(5), 45081 .

Spathis, C., Petridou, E., \& Glaveli, N. (2004). Managing service quality in banks: Customers' gender effects. Managing Service Quality, 14(1), 90.

Stewart, D. W. (1981). The application and misapplication of factor analysis in marketing research. Journal of Marketing Research, 18(1), 51-62.

Stewart, K. (1994). Customer exit: Loyalty issues in retail banking. Irish Marketing Review, 7, 45-53.

Stewart, K. (1998). An exploration of customer exit in retail banking. International Journal of Bank Marketing, 16(1), 6-14.

Strieter, J., Gupta, A. K., Raj, S. P., \& Wilemon, D. (1999). Product management and marketing of financial services. The International Journal of Bank Marketing, 17(7), 342-355.

Studenmund, W. H. (2001). Economic analysis (2nd ed.). Macmillan Publishing Company. 
Stynes, D. J., \& Peterson, G. L. (1984). A Review of logit models with implications for modelling recreation choices. Journal of Leisure Research, 16(4), 295-310.

Tan, C. T., \& Chuo, C. (1986). Intention, attitude and social influences in bank selection: A stud in an oriental culture. International Journal of Bank Marketing, 4(3), 43-53.

Taylor, G. A., Roos, I. \& Hamer, L. (2009). Service separation anxiety: Understanding consumer reaction to involuntary switching. Retrived July 1, 2009 from http://www.ihroos.fi/switching.html

Train, K. (1986). Qualitative choice analysis: Theory, economics, and an application to automobile demand. (3rd ed.). MIT press, Cambridge, Masachusetts, London.

Trubik, E., \& Smith, M. (2000). Developing a model of customer defection in the Australian banking industry. Managerial Auditing Journal, 15(5), 1-12.

Varki, S. \& Colgate, M. (2001). The role of price perception in an integrated model behavioral intention. Journal of Service Research, 3(3), 232-241.

Vendelo, M. T. (1998). Narrating corporate reputation. International studies of management and organization, 28(3), 120-137.

Wang, Y. G., Lo, H. P., \& Hui, Y. V. (2003). The antecedents of service quality and product reputation: Evidence from the bank industry in China. Managing Service Quality, 13(1), 72-84.

Weigelt, K., \& Camerer, C. (1988). Reputation and corporate strategy: A review of recent theory and application. Strategic Management Journal, 9(5), 443-454.

Winsted, K.F. (1997). The service experience in two cultures: A behavioural perspective. Journal of Retailing, 73(3), 337-60.

Yoon, E., Guffey, H. J., \& Kijewski, V. (1993). The effects of information and company reputation on intentions to buy a business service. Journal of Business Research, 27, 215-28.

Yue, H., \& Tom, G. (1995). How the Chinese select their banks. Journal of Retail Banking, XVI(4),36-39.

Zeithaml, V.A. (1998). Customer perceptions of price, quality and value: A meansend model and synthesis of evidence. Journal of Marketing, 52, July, 2-22.

Zeithaml, V.A., Berry, L., \& Parasuraman, A. (1996). The behavioural consequences of service quality. Journal of Marketing, 60(2), 31-46.

Zhou, L. (2004). A Dimension-specific analysis of performance-only measurement of service quality and satisfaction in China's retail banking. The Journal of Services Marketing, 18(6/7), 534. 
Table 5.1: Descriptive Statistic of Demographic Characteristics

\begin{tabular}{|c|c|c|c|c|c|c|c|c|}
\hline \multirow[t]{2}{*}{ Variables } & \multirow[t]{2}{*}{$\mathbf{N}$} & & \multicolumn{2}{|c|}{ Total Respondents } & \multicolumn{2}{|c|}{ Switching Banks } & \multicolumn{2}{|c|}{ Non-switching Banks } \\
\hline & & & $\begin{array}{l}\text { Frequency } \\
\text { (No. of } \\
\text { respondents } \\
\text { per option) }\end{array}$ & Percent & $\begin{array}{l}\text { Frequency } \\
\text { (No. of } \\
\text { respondents } \\
\text { per option) }\end{array}$ & Percent & $\begin{array}{l}\text { Frequency } \\
\text { (No. of } \\
\text { respondents } \\
\text { per option) }\end{array}$ & Percent \\
\hline \multirow[t]{3}{*}{ Gender } & \multirow[t]{3}{*}{ Valid } & Male & 217 & 51.5 & 79 & 51.6 & 138 & 51.5 \\
\hline & & Female & 204 & 48.5 & 74 & 48.4 & 130 & 48.5 \\
\hline & & Total & 421 & 100.0 & 153 & 100.0 & 268 & 100.0 \\
\hline \multirow[t]{8}{*}{ Age } & Valid & $18-25$ & 37 & 8.8 & 19 & 12.4 & 18 & 6.7 \\
\hline & & $26-35$ & 197 & 46.8 & 72 & 47.1 & 125 & 46.6 \\
\hline & & $36-45$ & 123 & 29.2 & 41 & 26.8 & 82 & 30.6 \\
\hline & & $46-55$ & 38 & 9.0 & 13 & 8.5 & 25 & 9.3 \\
\hline & & $56-65$ & 15 & 3.6 & 4 & 2.6 & 11 & 4.1 \\
\hline & & $66-75$ & 10 & 2.4 & 4 & 2.6 & 6 & 2.2 \\
\hline & & $75+$ & 1 & .2 & & & 1 & .4 \\
\hline & & Total & 421 & 100.0 & 153 & 100.0 & 268 & 100.0 \\
\hline \multirow[t]{9}{*}{ Education } & Valid & $\begin{array}{l}\text { Primary } \\
\text { Education }\end{array}$ & 1 & .2 & & & 1 & .4 \\
\hline & & $\begin{array}{l}\text { Middle School } \\
\text { Education }\end{array}$ & 40 & 9.5 & 14 & 9.2 & 26 & 9.7 \\
\hline & & $\begin{array}{l}\text { High School } \\
\text { Education }\end{array}$ & 92 & 21.9 & 36 & 23.5 & 56 & 20.9 \\
\hline & & $\begin{array}{l}\text { Diploma/ } \\
\text { Certification }\end{array}$ & 115 & 27.3 & 42 & 27.5 & $\% 73$ & 27.2 \\
\hline & & Bachelor Degree & 151 & 35.9 & 52 & 34.0 & 99 & 36.9 \\
\hline & & $\begin{array}{l}\text { Postgraduate } \\
\text { Degree }\end{array}$ & 15 & 3.6 & 7 & 4.6 & 8 & 3.0 \\
\hline & & P.H.D & 7 & 1.7 & 2 & 1.3 & 5 & 1.9 \\
\hline & & Other & & & & & & \\
\hline & & Total & 421 & 100.0 & 153 & 100.0 & 268 & 100.0 \\
\hline \multirow[t]{12}{*}{ Occupation } & Valid & Professional & 71 & 16.9 & 37 & 24.2 & 34 & 12.7 \\
\hline & & Self-employed & 39 & 9.3 & 15 & 9.8 & 24 & 9.0 \\
\hline & & Student & 19 & 4.5 & 10 & 6.5 & 9 & 3.4 \\
\hline & & Civil Servant & 80 & 19.0 & 25 & 16.3 & 55 & 20.5 \\
\hline & & Labour & 66 & 15.7 & 17 & 11.1 & 49 & 18.3 \\
\hline & & Farmer & 9 & 2.1 & 3 & 2.0 & 6 & 2.2 \\
\hline & & Unemployed & 19 & 4.5 & 10 & 6.5 & 9 & 3.4 \\
\hline & & Retired & 15 & 3.6 & 7 & 4.6 & 8 & 3.0 \\
\hline & & Sale/Service & 42 & 10.0 & 13 & 8.5 & 29 & 10.8 \\
\hline & & Home Maker & 18 & 4.3 & 5 & 3.3 & 13 & 4.9 \\
\hline & & Other & 43 & 10.2 & 11 & 7.2 & 32 & 11.9 \\
\hline & & Total & 421 & 100.0 & 153 & 100.0 & 268 & 100.0 \\
\hline \multirow[t]{6}{*}{ Income } & Valid & CNY499- & 58 & 13.8 & 12 & 7.8 & 46 & 17.2 \\
\hline & & CNY 500-2,999 & 254 & 60.3 & 84 & 54.9 & 170 & 63.4 \\
\hline & & CNY 3,000-5,999 & 77 & 18.3 & 37 & 24.2 & 40 & 14.9 \\
\hline & & CNY 6,000-9,999 & 23 & 5.5 & 14 & 9.2 & 9 & 3.4 \\
\hline & & CNY 10,000+ & 9 & 2.1 & 6 & 3.9 & 3 & 1.1 \\
\hline & & Total & 421 & 100.0 & 153 & 100.0 & 268 & 100.0 \\
\hline
\end{tabular}




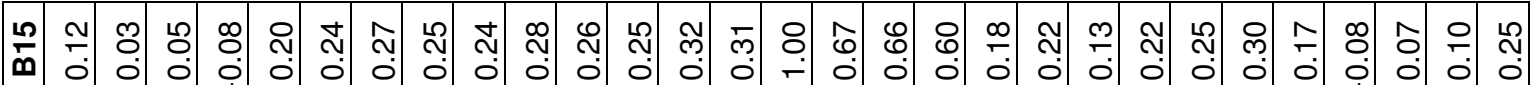

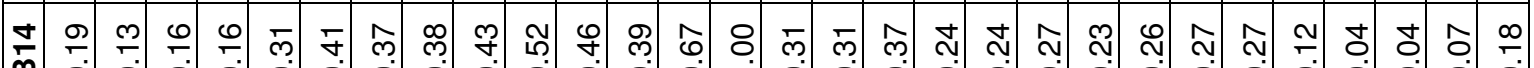

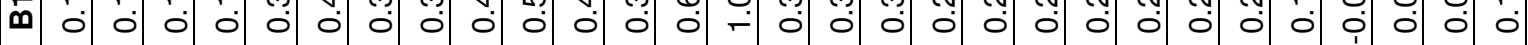

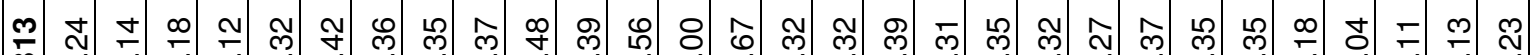
m

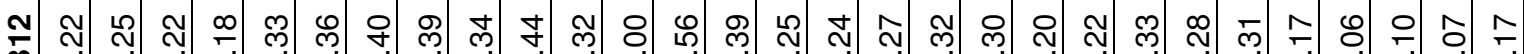

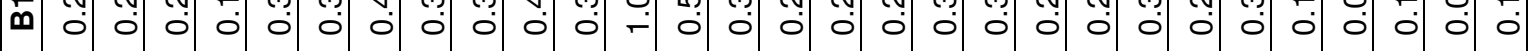

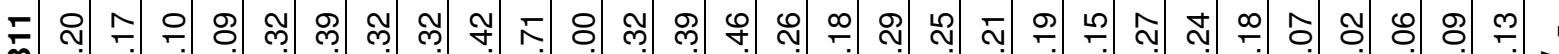

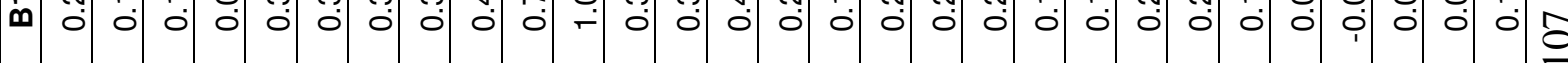

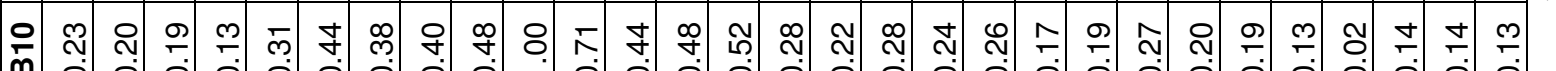

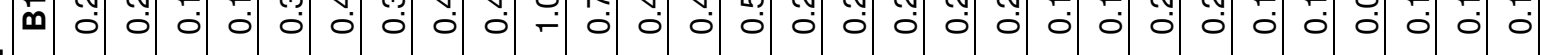
ว

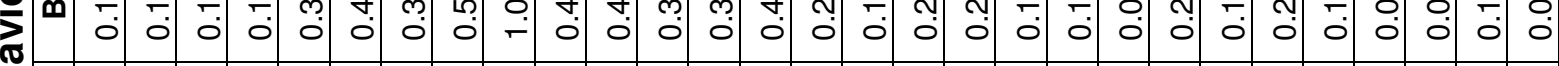
Џ) ๓ .ำ ผุ

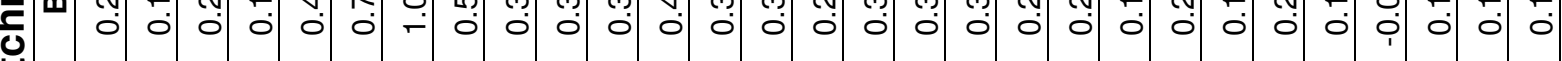
๓ లి ๆ

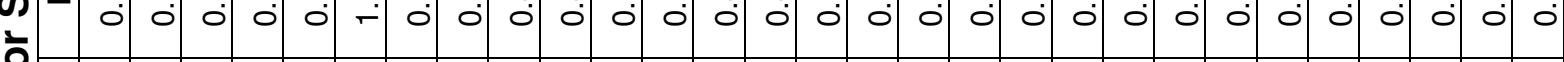
นొ

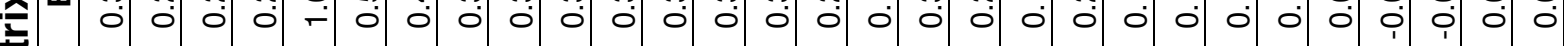

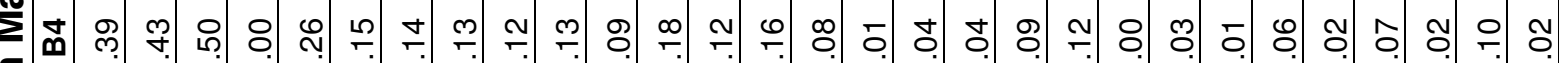
c స

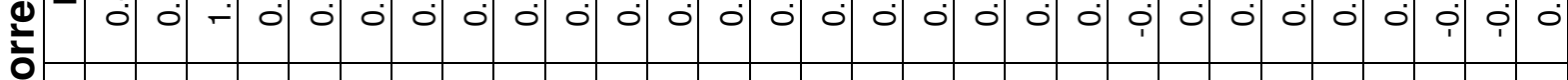
ป

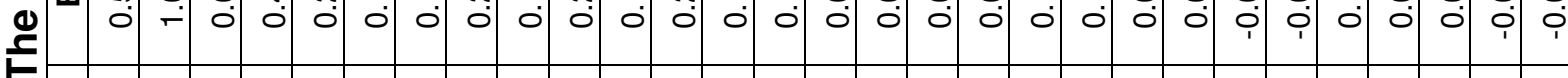
ஸ゙

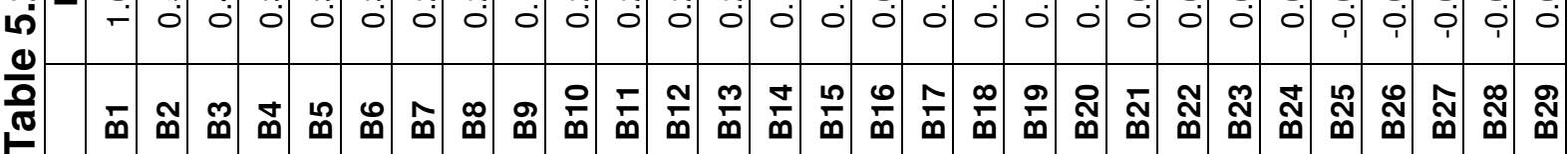




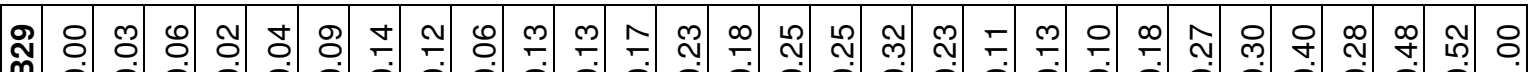

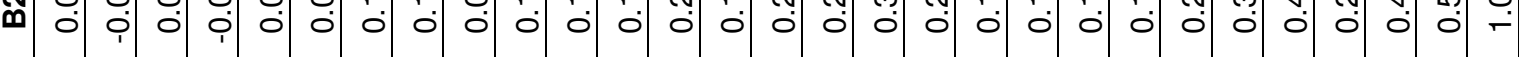

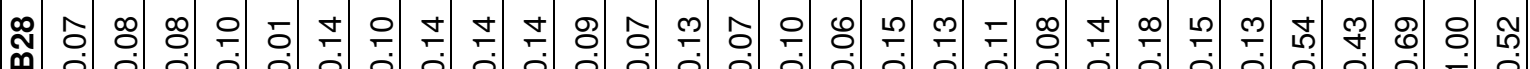

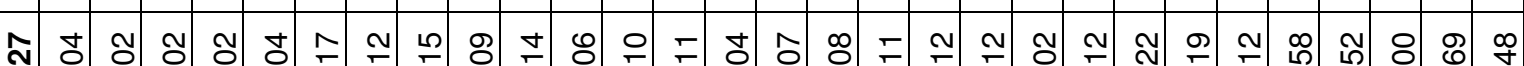

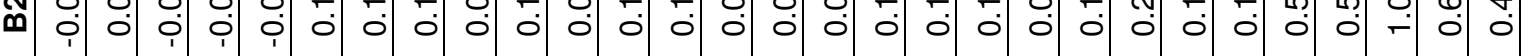

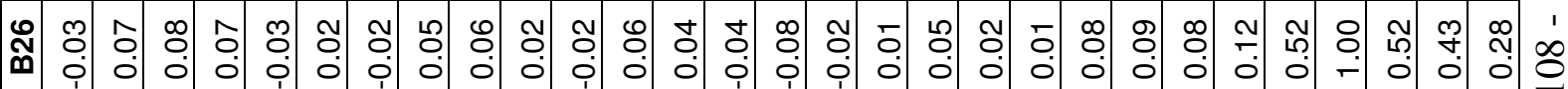

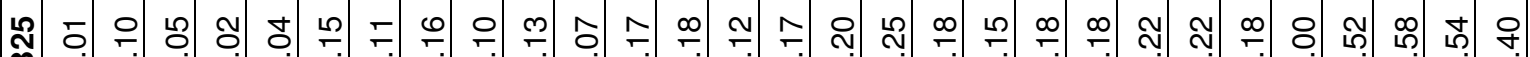

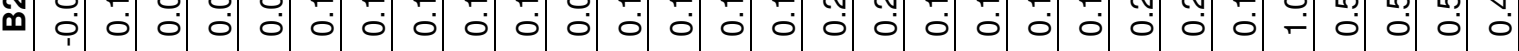

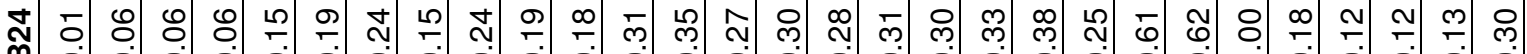
m $\begin{array}{llllllllllllllllllllllllllllll} & 0 & 0 & 0 & 0 & 0 & 0 & 0 & 0 & 0 & 0 & 0 & 0 & 0 & 0 & 0 & 0 & 0 & 0 & 0 & 0 & 0 & 0 & - & 0 & 0 & 0 & 0 & 0\end{array}$

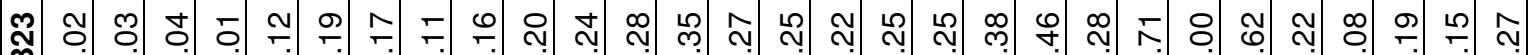

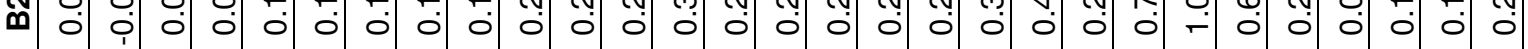

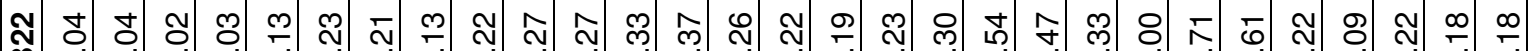
س.

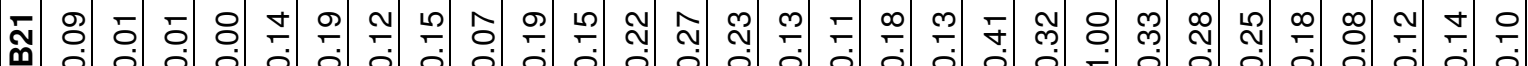

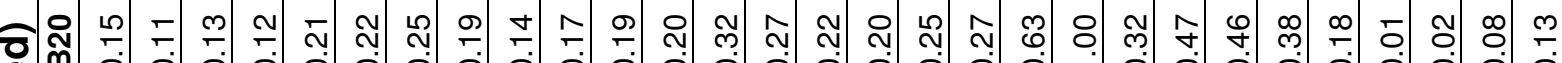

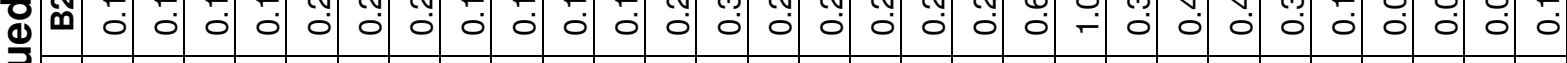
드 들 Uృ × 둔

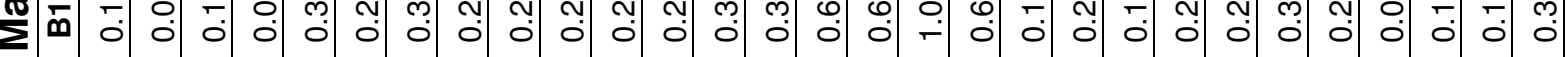

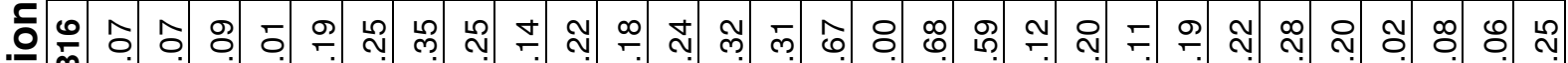
自 
ก⿻

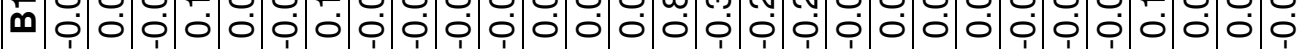

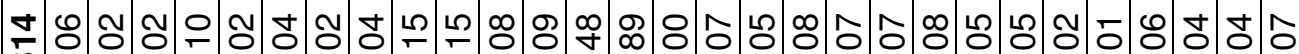

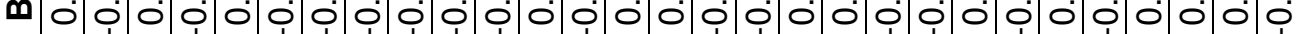

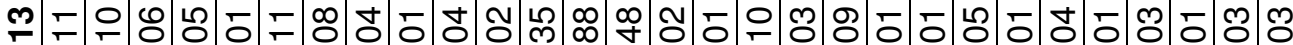

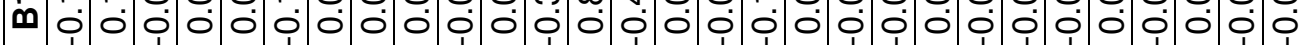

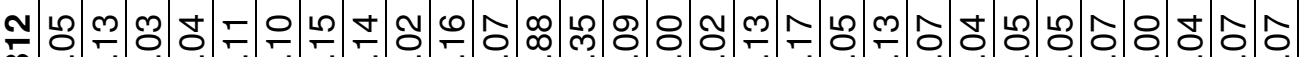

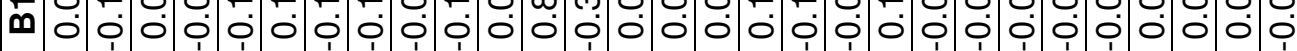

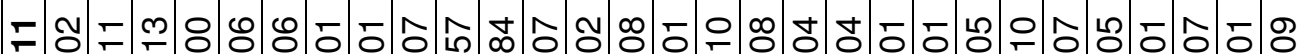

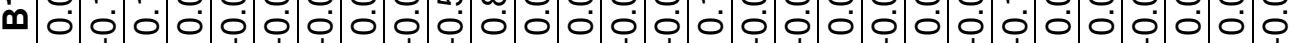

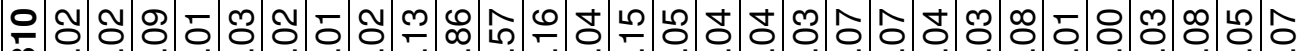

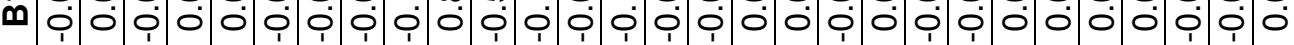

๓

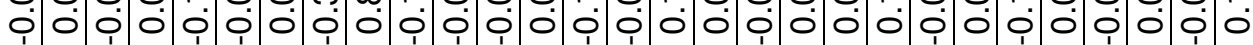

๓ o 1 i l

ஸิ

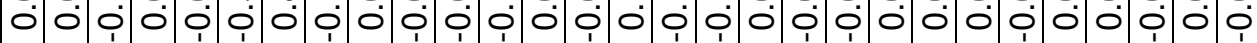

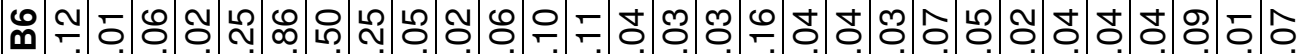

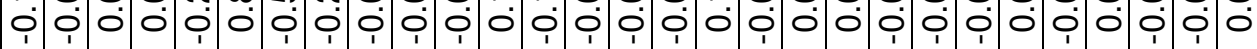

ผ ำㅇำ

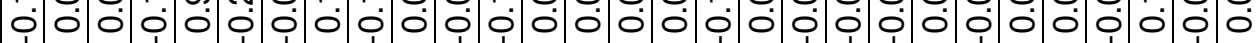

๓ i

๓

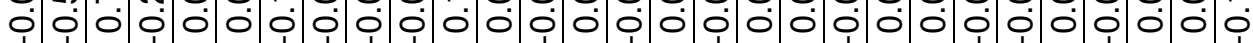

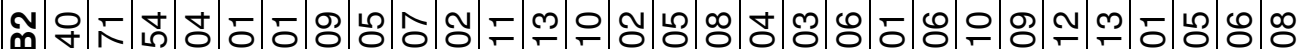

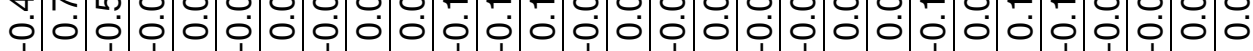

๓̄

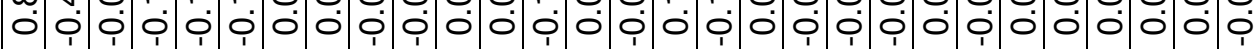

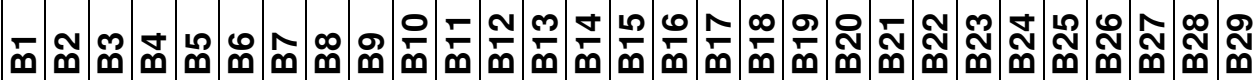


มิ่ง

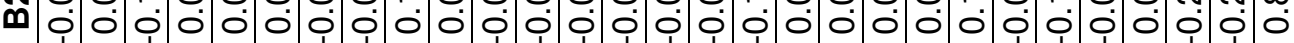

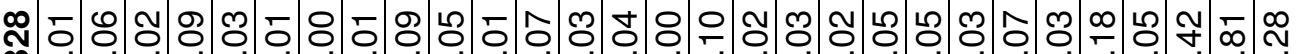

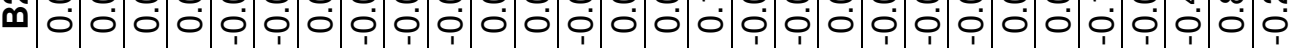

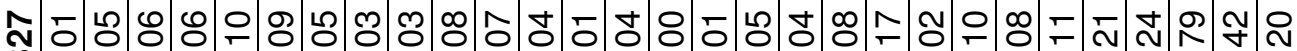

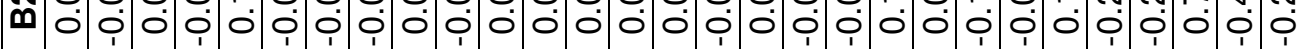

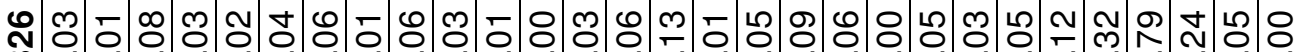

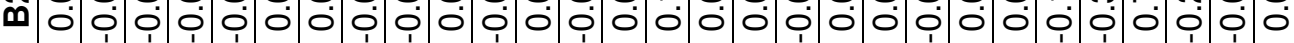

ผ

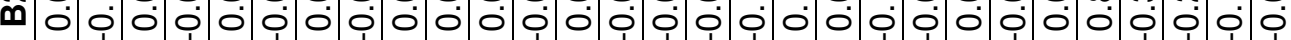

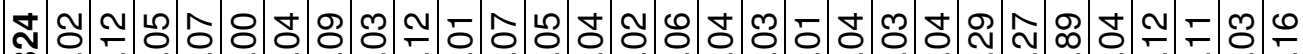

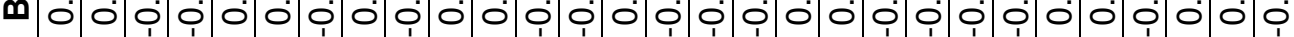

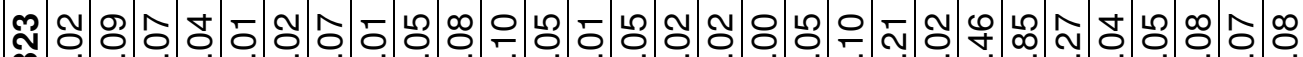

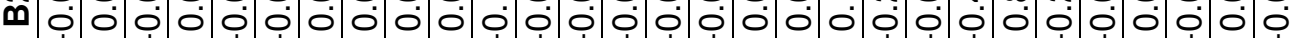

สิ

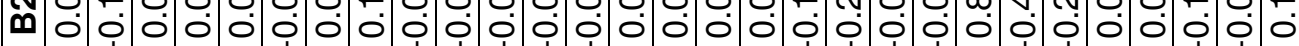

ন

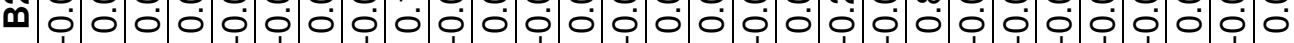

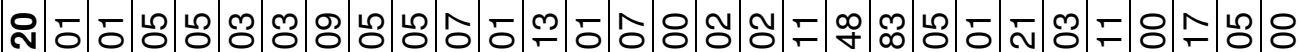

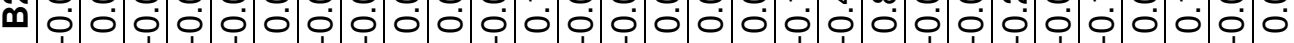

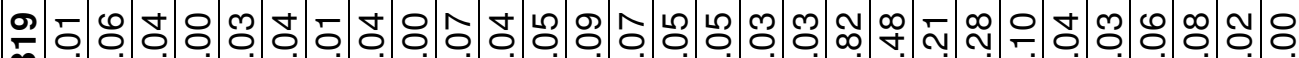

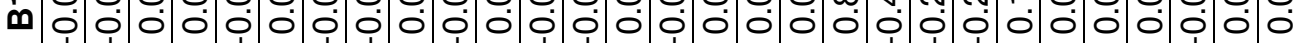

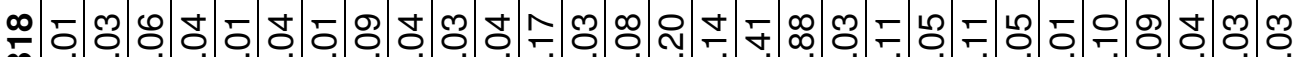

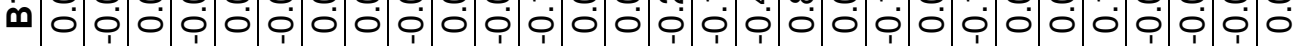

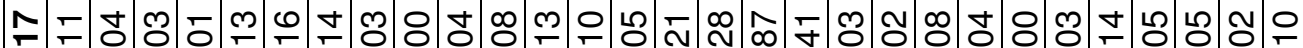
m

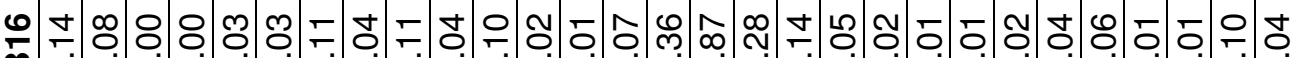

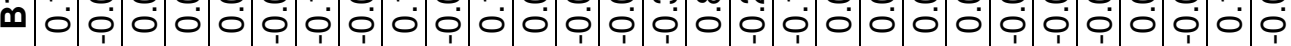


Table 5.4 KMO and Bartlett's Test

\begin{tabular}{|c|c|c|}
\hline \multicolumn{2}{|c|}{$\begin{array}{l}\text { Kaiser-Meyer-Olkin Measure of Sampling } \\
\text { Adequacy. }\end{array}$} & .854 \\
\hline $\begin{array}{l}\text { Bartlett's Test of } \\
\text { Sphericity }\end{array}$ & $\begin{array}{l}\text { Approx. Chi-Square } \\
\text { df } \\
\text { Sig. }\end{array}$ & $\begin{array}{r}5993.329 \\
406 \\
.000\end{array}$ \\
\hline
\end{tabular}

Table 5.5 Factor Extraction

\begin{tabular}{|c|c|c|c|c|c|c|}
\hline \multirow{2}{*}{ Component } & \multicolumn{3}{|c|}{ Initial Eigenvalues } & \multicolumn{3}{|c|}{ Extraction Sums of Squared Loadings } \\
\hline & Total & $\%$ of Variance & Cumulative \% & Total & $\%$ of Variance & Cumulative \% \\
\hline 1 & 7.543 & 26.011 & 26.011 & 7.543 & 26.011 & 26.011 \\
\hline 2 & 3.213 & 11.078 & 37.089 & 3.213 & 11.078 & 37.089 \\
\hline 3 & 2.395 & 8.260 & 45.349 & 2.395 & 8.260 & 45.349 \\
\hline 4 & 2.093 & 7.218 & 52.566 & 2.093 & 7.218 & 52.566 \\
\hline 5 & 1.828 & 6.303 & 58.869 & 1.828 & 6.303 & 58.869 \\
\hline 6 & 1.152 & 3.972 & 62.841 & 1.152 & 3.972 & 62.841 \\
\hline 7 & 1.004 & 3.463 & 66.304 & 1.004 & 3.463 & 66.304 \\
\hline 8 & .849 & 2.928 & 69.232 & & & \\
\hline 9 & .772 & 2.661 & 71.892 & & & \\
\hline 10 & .763 & 2.631 & 74.523 & & & \\
\hline 11 & .710 & 2.447 & 76.970 & & & \\
\hline 12 & .649 & 2.237 & 79.207 & & & \\
\hline 13 & .628 & 2.166 & 81.373 & & & \\
\hline 14 & .584 & 2.015 & 83.388 & & & \\
\hline 15 & .522 & 1.801 & 85.189 & & & \\
\hline 16 & .471 & 1.625 & 86.814 & & & \\
\hline 17 & .436 & 1.505 & 88.319 & & & \\
\hline 18 & .402 & 1.385 & 89.704 & & & \\
\hline 19 & .371 & 1.278 & 90.981 & & & \\
\hline 20 & .338 & 1.164 & 92.145 & & & \\
\hline 21 & .313 & 1.079 & 93.224 & & & \\
\hline 22 & .295 & 1.019 & 94.243 & & & \\
\hline 23 & .292 & 1.007 & 95.250 & & & \\
\hline 24 & .268 & .924 & 96.173 & & & \\
\hline 25 & .258 & .891 & 97.064 & & & \\
\hline 26 & .244 & .843 & 97.907 & & & \\
\hline 27 & .218 & .751 & 98.658 & & & \\
\hline 28 & .199 & .688 & 99.346 & & & \\
\hline 29 & .190 & .654 & 100.000 & & & \\
\hline
\end{tabular}


Table 5.6 Rotated Component Matrix with VARIMAX Rotation

\begin{tabular}{|c|c|c|c|c|c|c|c|}
\hline & \multicolumn{7}{|c|}{ Component } \\
\hline & 1 & 2 & 3 & 4 & 5 & 6 & 7 \\
\hline B17 & .839 & & & & & & \\
\hline B16 & .835 & & & & & & \\
\hline B15 & .815 & & & & & & \\
\hline B18 & .774 & & & & & & \\
\hline B27 & & .857 & & & & & \\
\hline B28 & & .817 & & & & & \\
\hline B25 & & .769 & & & & & \\
\hline B26 & & .735 & & & & & \\
\hline B29 & & .617 & & & & & \\
\hline B10 & & & .814 & & & & \\
\hline B11 & & & .777 & & & & \\
\hline B14 & & & .690 & & & & \\
\hline B13 & & & .614 & & & & \\
\hline B12 & & & & & & & \\
\hline B6 & & & & .817 & & & \\
\hline B7 & & & & .795 & & & \\
\hline B8 & & & & .716 & & & \\
\hline B5 & & & & .571 & & & \\
\hline B9 & & & & .518 & & & \\
\hline B2 & & & & & .845 & & \\
\hline B3 & & & & & .837 & & \\
\hline B4 & & & & & .718 & & \\
\hline B1 & & & & & .693 & & \\
\hline B24 & & & & & & .817 & \\
\hline B23 & & & & & & .799 & \\
\hline B22 & & & & & & .743 & \\
\hline B19 & & & & & & & .757 \\
\hline B21 & & & & & & & .731 \\
\hline B20 & & & & & & & .654 \\
\hline
\end{tabular}

Extraction Method: Principal Component Analysis.

Rotation Method: Varimax with Kaiser Normalization.

a Rotation converged in 7 iterations. 
Table 5.7 Pattern Matrix with OBLIMIN Rotation

\begin{tabular}{|c|c|c|c|c|c|c|c|}
\hline & \multicolumn{7}{|c|}{ Component } \\
\hline & 1 & 2 & 3 & 4 & 5 & 6 & 7 \\
\hline B10 & .852 & & & & & & \\
\hline B11 & .827 & & & & & & \\
\hline B14 & .688 & & & & & & \\
\hline B13 & .583 & & & & & & \\
\hline B12 & & & & & & & \\
\hline B2 & & -855 & & & & & \\
\hline B3 & & -851 & & & & & \\
\hline B4 & & -.726 & & & & & \\
\hline B1 & & -.672 & & & & & \\
\hline B27 & & & .863 & & & & \\
\hline B28 & & & .819 & & & & \\
\hline B25 & & & .765 & & & & \\
\hline B26 & & & .752 & & & & \\
\hline B29 & & & .590 & & & & \\
\hline B24 & & & & .835 & & & \\
\hline B23 & & & & .801 & & & \\
\hline B22 & & & & .722 & & & \\
\hline B16 & & & & & .860 & & \\
\hline B17 & & & & & .850 & & \\
\hline B15 & & & & & .830 & & \\
\hline B18 & & & & & .784 & & \\
\hline B6 & & & & & & .856 & \\
\hline B7 & & & & & & .848 & \\
\hline B8 & & & & & & .737 & \\
\hline B5 & & & & & & .567 & \\
\hline B9 & & & & & & & \\
\hline B21 & & & & & & & .744 \\
\hline B19 & & & & & & & .734 \\
\hline B20 & & & & & & & .615 \\
\hline
\end{tabular}

Extraction Method: Principal Component Analysis.

Rotation Method: Oblimin with Kaiser Normalization.

a Rotation converged in 12 iterations. 
Table 5.8: Questionnaire Items with Orthogonal (VARIMAX) Rotation

\begin{tabular}{|c|c|c|c|c|c|c|c|c|}
\hline & & \multicolumn{7}{|c|}{ Component } \\
\hline & & 1 & 2 & 3 & 4 & 5 & 6 & 7 \\
\hline B17 & Competing bank's card design & .839 & & & & & & \\
\hline B16 & Competing bank's signs or billboards & .835 & & & & & & \\
\hline B15 & Competing bank's advertising content & .815 & & & & & & \\
\hline B18 & Competing bank's promotion activity & .774 & & & & & & \\
\hline B27 & Length of time to familiar with new bank's policies & & .857 & & & & & \\
\hline B28 & Length of time to fill out forms for new banks & & .817 & & & & & \\
\hline B25 & Length of time to switch banks & & .769 & & & & & \\
\hline B26 & Cost to switch banks & & .735 & & & & & \\
\hline B29 & Whether receiving extra benefit from new banks & & .617 & & & & & \\
\hline B10 & Politeness and friend & & & .814 & & & & \\
\hline B11 & Service efficiency & & & .777 & & & & \\
\hline B14 & Consulting Service relatedness & & & .690 & & & & \\
\hline B13 & Service Specification & & & .614 & & & & \\
\hline B12 & Service product choices & & & & & & & \\
\hline B6 & Bank trustworthiness & & & & .817 & & & \\
\hline B7 & Bank financial stability & & & & .795 & & & \\
\hline B8 & Operation accuracy & & & & .716 & & & \\
\hline B5 & Bank system's reliability & & & & .571 & & & \\
\hline B9 & Whether providing service as promised & & & & .518 & & & \\
\hline B2 & Interest for loans & & & & & .845 & & \\
\hline B3 & Interest for mortgages & & & & & .837 & & \\
\hline B4 & Interest earning & & & & & .718 & & \\
\hline B1 & Bank fees & & & & & .693 & & \\
\hline B24 & Bank branch distance to shopping mall & & & & & & .817 & \\
\hline B23 & Bank branch distance to work place & & & & & & .799 & \\
\hline B22 & Bank branch distance to home & & & & & & .743 & \\
\hline B19 & Bank branch shutdown & & & & & & & .757 \\
\hline B21 & Compulsory salary bank & & & & & & & .731 \\
\hline B20 & Remove from the original bank location & & & & & & & .654 \\
\hline
\end{tabular}


Table 5.9: The Reliability Test for the Measures of Customers' Switching Behaviour

\begin{tabular}{|c|c|c|}
\hline Constructs & Items & Cronbach's Alpha \\
\hline Price & $\begin{array}{l}\text { 1. The bank charged low fees. } \\
\text { 2. The bank charges low interest for loans. } \\
\text { 3. The bank charges low interest for mortgages. } \\
\text { 4. The bank provides high interest rates on savings } \\
\text { accounts. }\end{array}$ & 0.799 \\
\hline Reputation & $\begin{array}{l}\text { 5. The bank's online system is reliable. } \\
\text { 6. The bank is trustworthy. } \\
\text { 7. The bank is financially stable. } \\
\text { 8. My bank account is administrated accurately. } \\
\text { 9. The bank provides services as promised. }\end{array}$ & 0.821 \\
\hline Service Quality & $\begin{array}{l}\text { 10. Bank staffs are polite and friendly. } \\
\text { 11. Bank staffs provide services efficiently. } \\
\text { 13. The service products satisfied my specific } \\
\text { needs. } \\
\text { 14. The bank's consulting service satisfied my } \\
\text { specific needs. }\end{array}$ & 0.823 \\
\hline Advertisement & $\begin{array}{l}\text { 15. The competing bank's advertising content did } \\
\text { not encourage me to switch banks. } \\
\text { 16. The signs or the billboards of the competing } \\
\text { bank did not encourage me to switch bank. } \\
\text { 17. The design of the competing bank's card did } \\
\text { not encourage me to switch bank. } \\
\text { 18. The promotion activity of the competing bank } \\
\text { influenced my decision to switch banks (eg. } \\
\text { attractive free gifts). }\end{array}$ & 0.880 \\
\hline $\begin{array}{l}\text { Involuntary } \\
\text { Factors }\end{array}$ & $\begin{array}{l}\text { 19. There are bank branches in my immediate } \\
\text { area. } \\
20 \text {. I have not moved outside of my principal bank's } \\
\text { geographic location. } \\
21 \text {. I did not change banks because my principal } \\
\text { bank is my employers' salary bank. }\end{array}$ & 0.710 \\
\hline Distance & $\begin{array}{l}\text { 22. The bank branch location is conveniently close } \\
\text { to my Home. } \\
23 \text {. The bank branch locations is conveniently } \\
\text { close to my work place. } \\
\text { 24. The bank branch locations is conveniently } \\
\text { close to malls or business centers. }\end{array}$ & 0.847 \\
\hline Switching Cost & $\begin{array}{l}25 \text {. It will take me too much time switch to a new } \\
\text { bank. } \\
26 \text {. It will cost me too much to switch to a new } \\
\text { bank. } \\
27 \text {. It will take me a long time to become familiar } \\
\text { with a new bank's policies. } \\
28 \text {. It will take me too much time to fill out forms to } \\
\text { switch to banks. } \\
\text { 29. I am not sure that I can receive any benefits if I } \\
\text { switch to a new bank (eg. China Merchants Bank } \\
\text { and China Southern Air-holding Company issue a } \\
\text { credit card enable the Customer to get air points on } \\
\text { the money they spend) }\end{array}$ & 0.833 \\
\hline
\end{tabular}




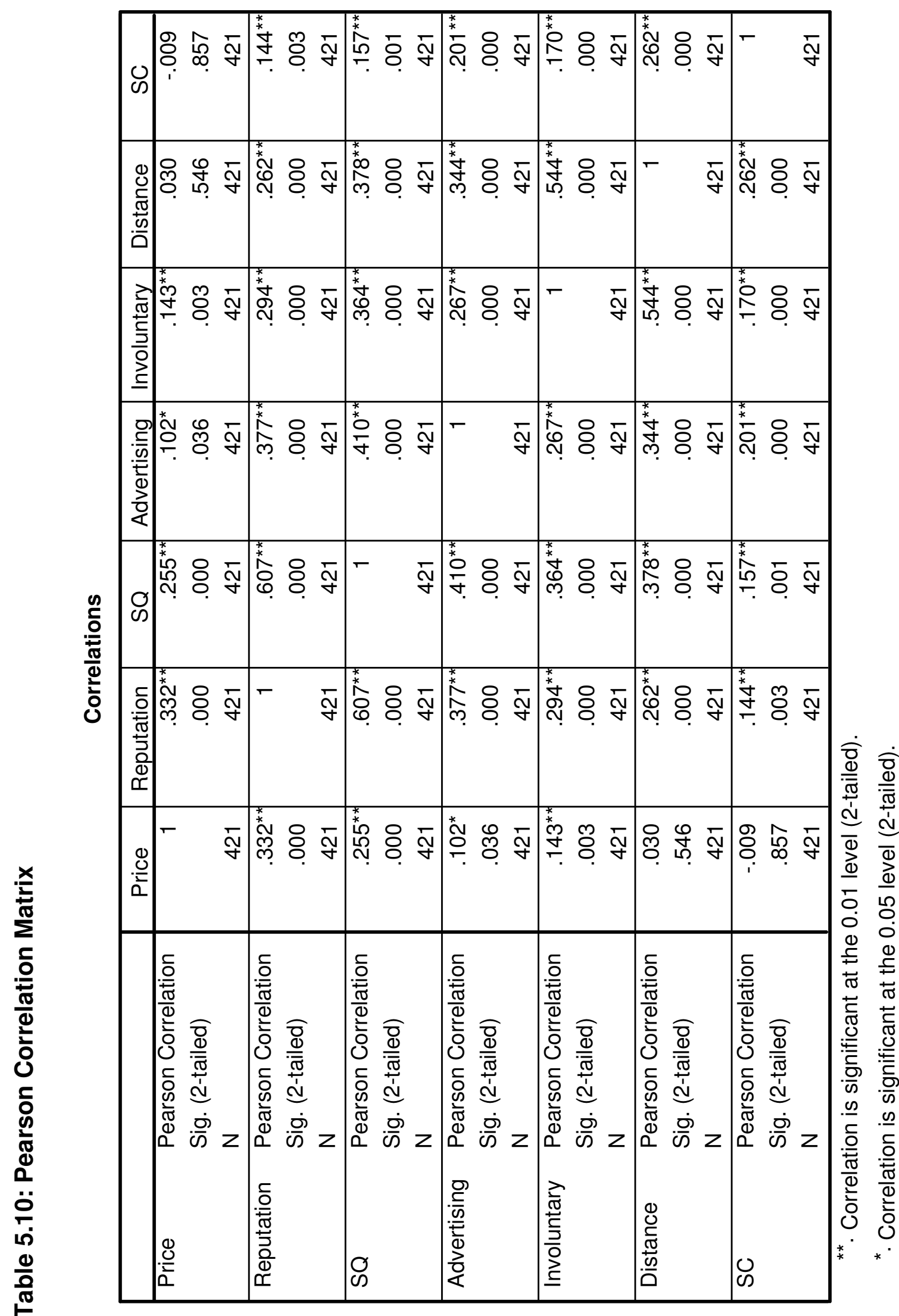

$\stackrel{1}{1}$ 
Table 5.11: Logistic Regression Results for Influencing Factors and Demographic Characteristics on Consumers' Switching Behaviour

\begin{tabular}{|c|c|c|c|c|}
\hline \multirow{7}{*}{\multicolumn{2}{|c|}{$\begin{array}{l}\text { Number of Observations: } \\
\text { Log likelihood function: } \\
\text { Restricted log likelihood: } \\
\text { Chi-Squared Statistics: } \\
\text { Degrees of Freedom: } \\
\text { Prob [ChiSqd > value]: } \\
\text { McFadden R2: }\end{array}$}} & \multicolumn{3}{|c|}{421} \\
\hline & & \multicolumn{3}{|c|}{-165.8811} \\
\hline & & \multicolumn{3}{|c|}{-275.9069} \\
\hline & & \multicolumn{3}{|c|}{220.0517} \\
\hline & & \multicolumn{3}{|c|}{20} \\
\hline & & \multicolumn{3}{|c|}{0.000000} \\
\hline & & \multicolumn{3}{|c|}{0.39878} \\
\hline & Coefficients & Std Error & Sig. & Marginal Effects \\
\hline Price & 0.6382958675 & 0.10780649 & $0.0000^{* *}$ & 0.1263622656 \\
\hline Reputation & 0.2922517773 & 0.13183990 & $0.0266^{\star *}$ & $0.5785654992 \mathrm{E}-01$ \\
\hline Service Quality & -0.3418676948 & 0.11901619 & $0.0041^{* *}$ & $-0.6767892236 \mathrm{E}-01$ \\
\hline Advertising & -0.2189922320 & 0.10649909 & $0.0398^{\star *}$ & $-0.4335349170 \mathrm{E}-01$ \\
\hline Involuntary & -0.2042865681 & 0.10923901 & $0.0615^{\star}$ & $-0.4044223831 E-01$ \\
\hline Distance & -0.33161821631 & 0.10211175 & $0.0010^{* *}$ & $-0.6655336805 E-01$ \\
\hline Switch Cost & -0.7639835055 & 0.11106939 & $0.0000^{* *}$ & -0.1512444175 \\
\hline Gender & 0.1522452158 & 0.28459101 & 0.5927 & $0.3016650012 \mathrm{E}-01$ \\
\hline Young Age & 1.720395399 & 0.57502399 & $0.0028^{* *}$ & 0.3990122162 \\
\hline Middle Age & 0.5992317754 & 0.40396487 & 0.1380 & 0.1193081199 \\
\hline Middle Old Age & 0.6149308886 & 0.42821968 & 0.1510 & 0.1281042800 \\
\hline Middle Education & 0.6070547838 & 0.50453194 & 0.2289 & 0.1286047738 \\
\hline Middle H Education & -0.2916282586 & 0.52627681 & 0.5795 & $-0.5593863409 E-01$ \\
\hline High Education & $-0.3204989397 E-01$ & 0.51071277 & 0.9500 & $-0.6336540076 \mathrm{E}-02$ \\
\hline White Collar & 1.214198189 & 0.44612120 & $0.0065^{\star *}$ & 0.2649138312 \\
\hline Civil Servant & 0.4566203139E-01 & 0.47083339 & 0.9927 & 0.9097228262E-02 \\
\hline Blue Collar & 0.5419278468 & 0.48984250 & 0.2686 & 0.1150617378 \\
\hline Others & 1.012436158 & 0.44468211 & $0.0228^{* *}$ & 0.2204794354 \\
\hline Middle Income & 1.613408192 & 0.50842711 & $0.0015^{\star *}$ & 0.2909518997 \\
\hline Middle $\mathrm{H}$ Income & 2.665511950 & 0.59058589 & $0.0000^{\star *}$ & 0.5807151847 \\
\hline High Income & 3.247592208 & 0.69255072 & $0.0000^{\star *}$ & 0.6565841125 \\
\hline \multicolumn{5}{|c|}{ Prediction Classification } \\
\hline \multicolumn{5}{|c|}{ Actual $0 \begin{array}{l}1 \\
\end{array}$} \\
\hline \\
\hline \multicolumn{5}{|c|}{\begin{tabular}{lll|l}
1 & 45 & 108 & 153
\end{tabular}} \\
\hline \multirow{2}{*}{\multicolumn{5}{|c|}{$\begin{array}{lll} & \\
\text { Total } & 289 & 132\end{array}$}} \\
\hline & 421 & & & \\
\hline Note: & ianificont ot 010 lo & anifio & & \\
\hline
\end{tabular}


Table 5.17: T-Test: Switching Behaviour Factor Relating to Gender

\begin{tabular}{|l|l|r|r|r|r|}
\hline Factor & Gender & N & \multicolumn{1}{|l|}{ Mean } & T & \multicolumn{1}{l|}{ Sig. } \\
\cline { 1 - 4 } Distance & Male & 217 & 4.407 & \multirow{2}{*}{-1.585} & $0.025^{\star *}$ \\
\cline { 1 - 4 } & Female & 204 & 4.683 & & \\
\hline
\end{tabular}

** significance at the 0.05 level.

*significance at the 0.10 level.

Table 5.18 ANOVA (F-tests) Results Relating to Age

\begin{tabular}{|l|l|r|r|r|c|}
\hline \multicolumn{1}{|c|}{ Factor } & \multicolumn{1}{|c|}{ Age } & $\begin{array}{c}\text { No. of } \\
\text { Respondents }\end{array}$ & Mean & F & Sig. \\
\hline Reputation & Young & 37 & 4.492 & 2.419 & $0.066^{*}$ \\
& Middle & 197 & 5.157 & & \\
& Middle-Old & 123 & 5.042 & & \\
& Old & 64 & 5.163 & & \\
\hline Service Quality & Young & 37 & 4.588 & 2.908 & $0.034^{\star *}$ \\
& Middle & 197 & 4.680 & & \\
& Middle-Old & 123 & 4.835 & & \\
& Old & 64 & 5.320 & & \\
\hline Involuntary Switching & Young & 37 & 4.180 & 2.226 & $0.085^{\star}$ \\
& Middle & 197 & 4.528 & & \\
& Middle-Old & 123 & 4.832 & & \\
& Old & 64 & 4.844 & & \\
\hline
\end{tabular}

**significance at the 0.05 level.

${ }^{*}$ significance at the 0.10 level. 
Table 5.19: ANOVA (F-tests) Results Relating to Education

\begin{tabular}{|l|l|l|l|l|l|}
\hline Factor & Education & $\begin{array}{l}\text { No. of } \\
\text { Respondents }\end{array}$ & Mean & F & \multirow{2}{*}{ Sig. } \\
\hline \multirow{3}{*}{ Service Quality } & Low & 41 & 4.860 & \multirow{2}{*}{2.719} & \multirow{2}{*}{$0.044^{* *}$} \\
\cline { 2 - 4 } & Middle & 92 & 5.130 & & \\
\cline { 2 - 4 } & Middle-High & 115 & 4.911 & & \\
\cline { 2 - 4 } & High & 173 & 4.572 & & \\
\hline
\end{tabular}

${ }^{* *}$ significance at the 0.05 level.

*significance at the 0.10 level.

Table 5.20: ANOVA (F-tests) Results Relating to Income

\begin{tabular}{|c|c|c|c|c|c|}
\hline Factor & Income & $\begin{array}{l}\text { No. of } \\
\text { Respondents }\end{array}$ & Mean & $\mathbf{F}$ & Sig. \\
\hline \multirow[t]{4}{*}{ Involuntary } & Low & 58 & 4.379 & \multirow[t]{4}{*}{2.925} & \multirow[t]{4}{*}{$0.034^{* *}$} \\
\hline & Middle & 254 & 4.806 & & \\
\hline & Middle-High & 77 & 4.494 & & \\
\hline & High & 32 & 4.073 & & \\
\hline \multirow[t]{4}{*}{$\begin{array}{l}\text { Switching } \\
\text { Costs }\end{array}$} & Low & 58 & 3.852 & \multirow[t]{4}{*}{2.698} & \multirow[t]{4}{*}{$0.045^{* *}$} \\
\hline & Middle & 254 & 4.073 & & \\
\hline & Middle-High & 77 & 4.166 & & \\
\hline & High & 32 & 3.344 & & \\
\hline
\end{tabular}

${ }^{* *}$ significance at the 0.05 level.

${ }^{*}$ significance at the 0.10 level. 
Table 5.21: The Scheffe Output for Age-Multiple Comparisons

\begin{tabular}{|c|c|c|c|c|}
\hline & & & Reputation & Service Quality \\
\hline Scheff & (I) Age & (J) Age & Sig. & Sig. \\
\hline & Young & $\begin{array}{l}\text { Middle } \\
\text { Middle Old } \\
\text { Old }\end{array}$ & $\begin{array}{l}0.077^{\star} \\
0.231 \\
0.155\end{array}$ & $\begin{array}{l}0.991 \\
0.874 \\
0.172 \\
\end{array}$ \\
\hline & Middle & $\begin{array}{l}\text { Young } \\
\text { Middle-Old } \\
\text { Old }\end{array}$ & $\begin{array}{l}0.077^{*} \\
0.918 \\
1\end{array}$ & $\begin{array}{l}0.991 \\
0.867 \\
0.050^{* *}\end{array}$ \\
\hline & Middle-Old & $\begin{array}{l}\text { Young } \\
\text { Middle } \\
\text { Old }\end{array}$ & $\begin{array}{l}0.231 \\
0.918 \\
0.959 \\
\end{array}$ & $\begin{array}{l}0.874 \\
0.867 \\
0.269 \\
\end{array}$ \\
\hline & Old & $\begin{array}{l}\text { Young } \\
\text { Middle } \\
\text { Middle Old }\end{array}$ & $\begin{array}{l}0.155 \\
1 \\
0.959 \\
\end{array}$ & $\begin{array}{l}0.172 \\
0.050^{\star *} \\
0.269 \\
\end{array}$ \\
\hline
\end{tabular}

**significance at the 0.05 level.

*significance at the 0.10 level. 
Table 5.22: The Scheffe Output for Education-Multiple Comparisons

\begin{tabular}{|c|c|c|c|}
\hline & & & Service Quality \\
\hline \multirow[t]{13}{*}{ Scheff } & (I) Education & (J) Education & Sig. \\
\hline & Low & Middle & 0.843 \\
\hline & & Middle-High & 0.999 \\
\hline & & High & 0.779 \\
\hline & Middle & Low & 0.843 \\
\hline & & Middle-High & 0.806 \\
\hline & & High & $0.060^{*}$ \\
\hline & Middle-High & Low & 0.999 \\
\hline & & Middle & 0.806 \\
\hline & & High & 0.37 \\
\hline & High & Low & 0.779 \\
\hline & & Middle & $0.060^{*}$ \\
\hline & & Middle High & 0.37 \\
\hline
\end{tabular}

${ }^{* *}$ significance at the 0.05 level.

${ }^{*}$ significance at the 0.10 level. 
Table 5.23: The Scheffe Output for Income -Multiple Comparisons

\begin{tabular}{|c|c|c|c|}
\hline & & & Switching Cost \\
\hline Scheff & (I) Income & (J) Income & Sig. \\
\hline & Low & $\begin{array}{l}\text { Middle } \\
\text { Middle-High } \\
\text { High }\end{array}$ & $\begin{array}{l}0.798 \\
0.699 \\
0.509 \\
\end{array}$ \\
\hline & Middle & $\begin{array}{l}\text { Low } \\
\text { Middle-High } \\
\text { High }\end{array}$ & $\begin{array}{l}0.798 \\
0.974 \\
0.087^{*}\end{array}$ \\
\hline & Middle-High & $\begin{array}{l}\text { Low } \\
\text { Middle } \\
\text { High } \\
\end{array}$ & $\begin{array}{l}0.699 \\
0.974 \\
0.085^{*}\end{array}$ \\
\hline & High & $\begin{array}{l}\text { Low } \\
\text { Middle } \\
\text { Middle-High }\end{array}$ & $\begin{array}{l}0.509 \\
0.087^{*} \\
0.085^{*}\end{array}$ \\
\hline
\end{tabular}

**significance at the 0.05 level. ${ }^{*}$ significance at the 0.10 level. 


\section{Appendix 1: Cover Letter}
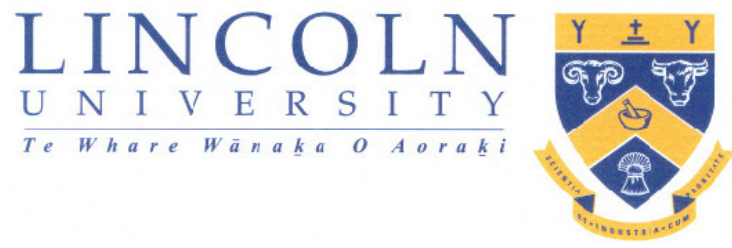

Commerce Division

P O Box 84

Lincoln University

Canterbury

New Zealand

Telephone:

(64)(3) 325281

Dear Sir/Madam

You are invited to participate in a survey that constitutes part of my Master of Commerce and Management thesis at Lincoln University, New Zealand. The survey is about people's experiences with banks and, where applicable, why people sometimes switch banks. The information you provide will be published in aggregate form only, in my thesis and in any resulting academic publications.

You are invited to participate in this research. Your participation is very important to this research. This survey will take approximately 10-15 minutes to complete. If you are 18 years or older, I would be grateful if you would take few minutes to complete the questionnaire and return it to me once you have finished. This research is completely voluntary in nature and you are free to decide not to participate at any time during the process of completing the questionnaire. However, if you complete the questionnaire and return it to the researcher, it will be understood that you are 18 years of age or older and have consented to participate in this survey.

Complete anonymity is assured in this survey, as the questionnaire is anonymous. No questions are asked which would identify you as an individual. All responses will be aggregated for analysis only, and no personal details will be reported in the thesis or any resulting publications.

If you have any questions about this survey, please contact me on (03) 3253838 (ext 8972), or by email at zhangdongmei1125@hotmail.com. You can also contact my supervisors Michael D. Clemes and Dr. Christopher Gan. Mr. Clemes can be contacted at (03) 3252811 (ext 8292) or Clemes@lincoln.ac.nz and Dr. Gan can be contacted at (03) 3252811 (ext 8155) or GanC1@lincoln.ac.nz.

This project has approved by Lincoln University Human Ethics Committee. Thank you for your kind co-operation and assistance.

Yours Sincerely

Dongmei Zhang

Master Student of Commerce and Management

Research Supervisors:

Mr Mike Clemes

Senior Lecturer Marketing

Commerce Division
Dr Christopher Gan

Associate Professor, Economics

Commerce Division 
A SURVEY OF CUSTOMERS' SWITCHING BEHAVIOUR IN THE CHINESE RETAIL BANKING INDUSTRY

Only those 18 years or older are asked to complete the questionnaire

\section{QUESTIONNAIRE}

This questionnaire contains four sections. Please respond to all of the statements in the relevant sections. Listed below are a series of statements that relate to your overall banking experience.

\section{SECTION ONE}

Please TICK the most appropriate box.

During the last three years, I have switched my principal bank. Your principal bank is the bank which you conduct the majority of my banking business.

If $\underline{\text { Yes}}$, Please go to $\underline{\text { Section Two. }}$

If $\underline{\text { No}}$, Please go to Section Three.

\section{SECTION TWO}

Please CIRCLE how strongly you agree or disagree with each of the following statements on a scale of 7 to 1. 1-you strongly disagree, 7-you strongly agree. PLEASE RELATE YOUR RESPONSES TO THE LAST BANK YOU LEFT WITHIN THE LAST THREE YEARS.

Strongly

Disagree
Strongly

Agree

1. The bank charged high fees $1 \quad 2 \quad 3$

2. The bank charged high interest for loans 123

3. The bank charged high interest for mortgages ..... $1 \quad 2 \quad 3$

4. The bank provided low interest rates on savings accounts.....

5. The bank's online system was unreliable....... 1

6. The bank was untrustworthy 1

7. The bank was financially unstable 1

$\begin{array}{llllll}2 & 3 & 4 & 5 & 6 & 7 \\ 2 & 3 & 4 & 5 & 6 & 7 \\ 2 & 3 & 4 & 5 & 6 & 7\end{array}$

Please turn the page and continue to complete Section Two 


\begin{tabular}{|c|c|c|c|c|c|c|}
\hline & Disagree & \multicolumn{3}{|c|}{ Neutral } & & Agre \\
\hline 8. My bank account was administrated incorrectly ...................... 1 & 2 & 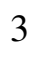 & 4 & 5 & & 7 \\
\hline 9. The bank provided services that were not as promised ........... 1 & 2 & J & 4 & 5 & & \\
\hline 10. Bank staff were impolite and rude.. & 2 & 3 & 4 & 5 & 6 & \\
\hline 11. Bank staff were slow to provide services & 2 & 3 & 4 & 5 & 6 & \\
\hline
\end{tabular}

12. The bank did not offer a wide range of service products (e.g. loans, mortgages, credit cards, online and phone banking, direct bills payment services). $\begin{array}{lllllll}1 & 2 & 3 & 4 & 5 & 6 & 7\end{array}$

13. The service products offered did not satisfy my specific needs $\begin{array}{llllll}2 & 3 & 4 & 5 & 6 & 7\end{array}$

14. The bank's consulting service did not satisfy my specific needs. $\begin{array}{llllll}2 & 3 & 4 & 5 & 6 & 7\end{array}$

15. The competing bank's advertising content influenced my decision to switch banks $\begin{array}{lllllll}1 & 2 & 3 & 4 & 5 & 6 & 7\end{array}$

16. The signs or billboards of the competing bank influenced my decision to switch banks. $\begin{array}{llllll}2 & 3 & 4 & 5 & 6 & 7\end{array}$

17. The design of the competing bank's card influenced my decision to switch banks $\begin{array}{llllll}2 & 3 & 4 & 5 & 6 & 7\end{array}$

18. The promotion activity of the competing bank influenced my decision to switch banks (eg. attractive free gifts) $\begin{array}{llllll}2 & 3 & 4 & 5 & 6 & 7\end{array}$

19. The principal bank branches in my area are closed. 1

20. I moved to a new geographic location and my principal bank is not in the area $\begin{array}{lllllll}1 & 2 & 3 & 4 & 5 & 6 & 7\end{array}$

21. I changed banks because my previous bank was not my employers' salary bank $\begin{array}{llllll}2 & 3 & 4 & 5 & 6 & 7\end{array}$

22. The bank branch locations are too far away from my home to be convenient. $\begin{array}{llllll}2 & 3 & 4 & 5 & 6 & 7\end{array}$

23. The bank branch locations are too far away from my work place to be convenient $\begin{array}{lllllll}1 & 2 & 3 & 4 & 5 & 6 & 7\end{array}$ 
Please turn the page and continue to complete Section Two

$\begin{array}{cc}\text { Strongly } & \text { Strongly } \\ \text { Disagree } & \text { Neutral }\end{array}$

24. The bank branch locations are not conveniently close to malls or business centres $\begin{array}{llllll}2 & 3 & 4 & 5 & 6 & 7\end{array}$

25. It will not take me too much time to switch to a new bank.... $1 \quad 2 \quad \begin{array}{lllllll}3 & 3 & 4 & 5 & 6 & 7\end{array}$

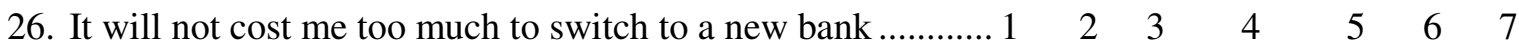

27. It will not take me a long time to become familiar with a

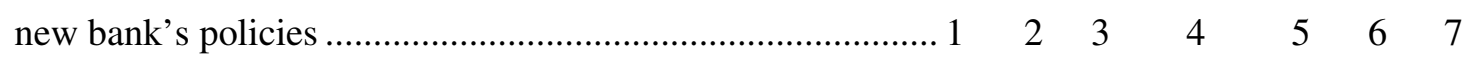

28. It will not take me a long time to fill out forms to join a new bank $\begin{array}{llllll}2 & 3 & 4 & 5 & 6 & 7\end{array}$

29. I am sure that I can receive additional benefits if I switch to a new bank (eg. China Merchants Bank and China Southern Air Holding Company issue a credit card enable customers to get air points on the money they spend) $\begin{array}{llllll}2 & 3 & 4 & 5 & 6 & 7\end{array}$ 


\section{SECTION THREE}

Please CIRCLE how strongly you agree or disagree with each of the following statements on a scale of 7 to 1. 1-you strongly disagree, 7-you strongly agree. PLEASE RELATE YOUR RESPONSES TO YOUR CURRENT BANK.

Strongly

Disagree

Neutral

Strongly

Agree

1.The bank charges low fees

$\begin{array}{llllll}2 & 3 & 4 & 5 & 6 & 7 \\ 2 & 3 & 4 & 5 & 6 & 7 \\ 2 & 3 & 4 & 5 & 6 & 7 \\ 2 & 3 & 4 & 5 & 6 & 7\end{array}$

5. The bank's online system is reliable 123

6. The bank is trustworthy 123

7. The bank is financially stable $\begin{array}{lllllll}1 & 2 & 3 & 4 & 5 & 6 & 7\end{array}$

8. My bank account is administrated accurately $\begin{array}{lllllll}1 & 2 & 3 & 4 & 5 & 6 & 7\end{array}$

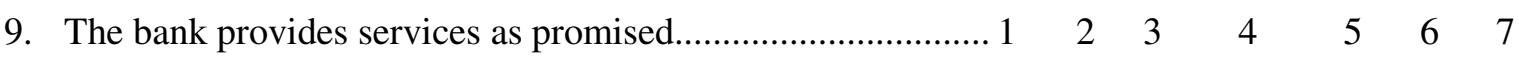

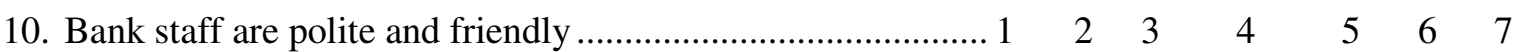

11. Bank staff provide services efficiently $\begin{array}{lllllll}1 & 2 & 3 & 4 & 5 & 6 & 7\end{array}$

12. The bank provides a wide range of service products (e.g. loans, mortgages, credit cards, online and phone banking, bills payment services) $\begin{array}{lllllll}1 & 2 & 3 & 4 & 5 & 6 & 7\end{array}$

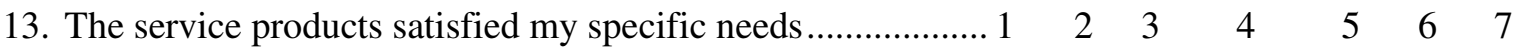

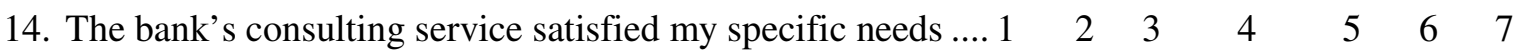

15. The competing bank's advertising content did not encourage me to switch banks $\begin{array}{llllll}2 & 3 & 4 & 5 & 6 & 7\end{array}$

16. The signs or the billboards of the competing bank did not encourage me to switch bank $\begin{array}{lllllll}1 & 2 & 3 & 4 & 5 & 6 & 7\end{array}$

17. The design of the competing bank's card did not encourage me to switch bank $\begin{array}{lllllll}1 & 2 & 3 & 4 & 5 & 6 & 7\end{array}$ 
18. The promotion activity of the competing bank influenced my decision to switch banks (eg. attractive free gifts) .

19. There are bank branches in my immediate area

$\begin{array}{llllll}2 & 3 & 4 & 5 & 6 & 7\end{array}$

20. I have not moved outside of my principal bank's geographic location

21. I did not change banks because my principal bank is my employers' salary bank $\begin{array}{llllll}2 & 3 & 4 & 5 & 6 & 7\end{array}$

22. The bank branch location is conveniently close to my home $\begin{array}{llllll}2 & 3 & 4 & 5 & 6 & 7\end{array}$

23. The bank branch locations is conveniently close to my work place $\begin{array}{llllll}2 & 3 & 4 & 5 & 6 & 7\end{array}$

24. The bank branch locations is conveniently close to malls or business centres $\begin{array}{llllll}2 & 3 & 4 & 5 & 6 & 7\end{array}$

25. It will take me too much time switch to a new bank $\begin{array}{llllll}2 & 3 & 4 & 5 & 6 & 7\end{array}$

26. It will cost me too much to switch to a new bank $\begin{array}{llllll}2 & 3 & 4 & 5 & 6 & 7\end{array}$

27. It will take me a long time to become familiar with a new bank's policies

28. It will take me too much times to fill out forms to switch to a banks

29. I am not sure that I can receive any benefits if I switch to a new bank (eg. China Merchants Bank and China Southern Air Holding Company issue a credit card enable customers to get air points on the money they spend)

\section{Please turn the page and continue to complete Section Four}




\section{SECTION FOUR}

The questions below relate to personal data. Please TICK the most appropriate box.

1. What is your gender?

Male $\square \quad$ Female

2. Which is your age group?
$18-25$
26-35
$36-45$
$46-55$
$56-65$
$66-75$
$76+$

3. Which is the highest level of education you have completed?

Primary Education

Diploma/Certificati

on

Other
Middle School

Education

High School Education

Bachelors Degree

Postgraduate Degree

\section{What is your occupation?}
Professional
Self-employed
Student
Civil Servant
Labourer
Farmer
Unemployed
Sale/Service
Home Maker
Other
Retired

6. What is your personal monthly income before tax? (Chinese CNY in the last month)
499-
$500-2,999$
$3,000-5,999$
$6,000-9,999$
$10,000+$

Your participation in this survey is greatly appreciated. Thank you for your time and if you have further comments about Bank Switching Behaviour, please feel free to comment in the space provided below. Once again, we assure you that identity will remain STRICTLY CONFIDENTIAL. 